Portland State University

PDXScholar

Winter 3-14-2014

\title{
Building and Maintaining Plankhouses at Two Villages on the Southern Northwest Coast of North America
}

Emily Evelyn Shepard

Portland State University

Follow this and additional works at: https://pdxscholar.library.pdx.edu/open_access_etds

Part of the American Art and Architecture Commons, Archaeological Anthropology Commons, and the Architectural Engineering Commons

Let us know how access to this document benefits you.

\section{Recommended Citation}

Shepard, Emily Evelyn, "Building and Maintaining Plankhouses at Two Villages on the Southern Northwest Coast of North America" (2014). Dissertations and Theses. Paper 1648.

https://doi.org/10.15760/etd.1647

This Thesis is brought to you for free and open access. It has been accepted for inclusion in Dissertations and Theses by an authorized administrator of PDXScholar. Please contact us if we can make this document more accessible: pdxscholar@pdx.edu. 
Building and Maintaining Plankhouses at Two Villages

on the Southern Northwest Coast of North America

\author{
by \\ Emily Evelyn Shepard
}

A thesis submitted in partial fulfillment of the requirements for the degree of

\author{
Master of Science \\ in \\ Anthropology
}

Thesis Committee:

Kenneth Ames, Chair

Shelby Anderson

Douglas Wilson

Portland State University

2014 


\begin{abstract}
Plankhouses were functionally and symbolically integral to Northwest Coast societies, as much of economic and social life was predicated on these dwellings. This thesis investigates both plankhouse architecture and the production of these structures. Studying plankhouse construction and maintenance provides information regarding everyday labor, landscape use outside of villages, organization of complex tasks, and resource management.

This thesis investigates three plankhouse structures at two sites, Meier and Cathlapotle, in the Lower Columbia River Region of the southern Northwest Coast of North America. Methods consisted of digitizing over 1,100 architectural features, creating detailed maps of architectural features, and conducting statistical and spatial analysis of these features. I use ethnographies, historical documents, experimental archaeology, and ecological studies to characterize the processes of plankhouse production. This information is combined with excavation data from Cathlapotle and Meier to calculate estimates of material and labor required for plankhouse-related activities.

Results of this study support previous inferences regarding house architecture, construction and maintenance at the two sites. Structural elements were frequently replaced, yet overall house appearance changed little over time. Some differences in structural element use and size are noted between the two sites, suggesting that slightly different building techniques may have been employed at the two villages.
\end{abstract}


Although approximate, calculations of raw materials and person days required for various building tasks provide a glimpse of the massive undertaking entailed in constructing and maintaining plankhouses. These data suggest that an enormous amount of trees were required for construction and maintenance over house occupation, approximately 700-1,200 trees at Meier, 900-2,000 trees at Cathlapotle House 1, and 150400 trees at Cathlapotle House 4. Estimates of minimum person days entailed for tasks related to initial construction range from 1,400-2,800 at Meier, to 2,100-4,500 at Cathlapotle House 1, to 350-700 at Cathlapotle House 4. In highlighting the articulation of plankhouse labor with household reproduction, this thesis demonstrates the important interplay between material outputs, everyday action, and sociopolitical aspects of Northwest Coast society. 


\section{Acknowledgements}

This project was made possible by work accomplished by past researchers at Meier and Cathlapotle, and by field school participants who excavated at the sites. Thanks so much to Ken Ames being such an excellent mentor and for encouraging me with his curiosity and humor. I appreciate Shelby Anderson and Doug Wilson for their helpful comments. Much thanks goes out to Connie Cash for constant logistical support, jokes and snacks, and to all of the PSU Anthropology Department for teaching me so much and for their patience with my shenanigans. I've benefited greatly from friendships and discussions with many fellow students at PSU, and support from family, friends and my husband David. Finally, I would like to dedicate this thesis to my grandma Sharon Shepard, who was a lifelong lover of learning. 


\section{Table of Contents}

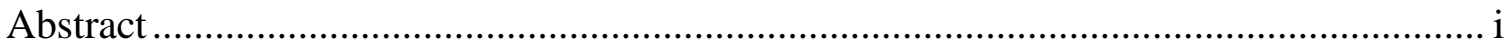

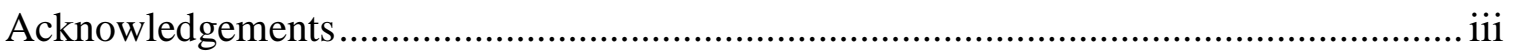

List of Figures ............................................................................................... vi

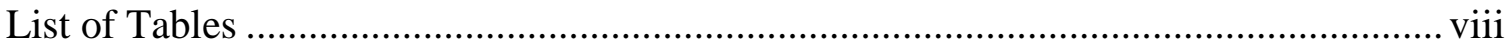

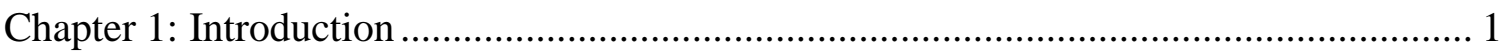

Chapter 2: Meier and Cathlapotle ............................................................................... 4

Site Contexts and Excavation Backgrounds................................................................. 4

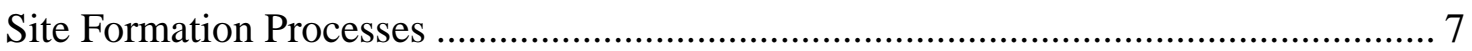

Prior House and Household Research .................................................................. 11

Chapter 3: Theoretical Orientation ....................................................................... 14

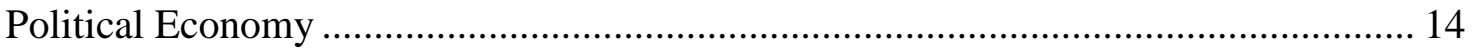

Household Archaeology ...................................................................................... 16

Household Archaeology on the Northwest Coast ....................................................... 20

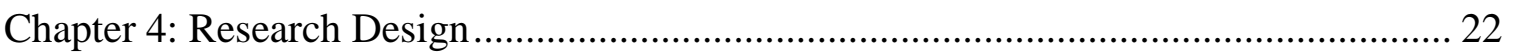

Research Questions and Hypotheses ....................................................................... 22

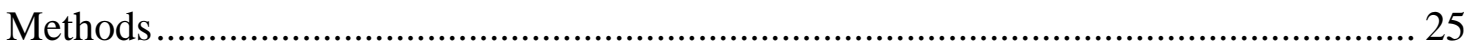

Chapter 5: Results of Plankhouse Construction and Maintenance History Analysis ....... 37

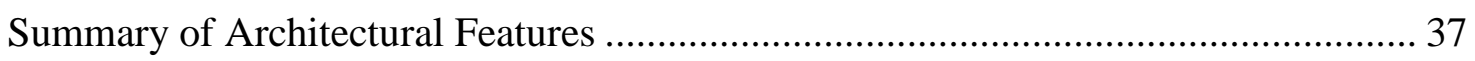

Plankhouse Construction and Maintenance History ……………………………......... 43

Chapter 6: Results of Plankhouses Labor Literature Review …………………………... 71

Plankhouse Construction and Maintenance ………………………………………........ 71

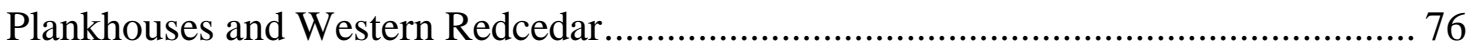

Chapter 7: Results of Plankhouse Labor Costs Calculations ............................................. 84

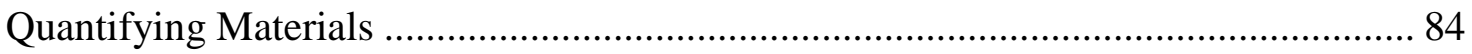

Plankhouse Construction Production Sequence ........................................................ 85

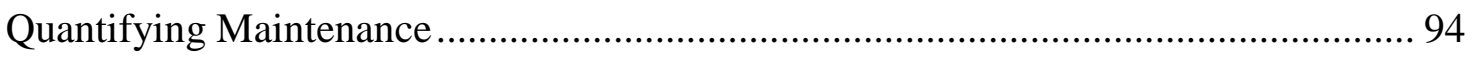

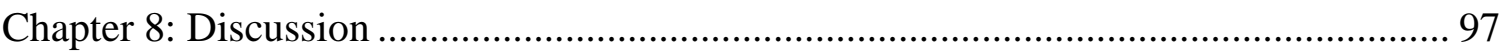

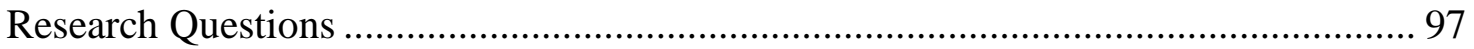




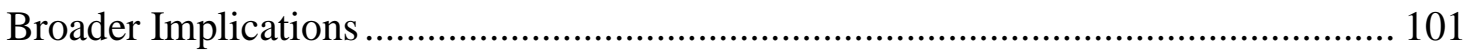

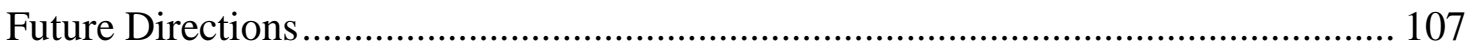

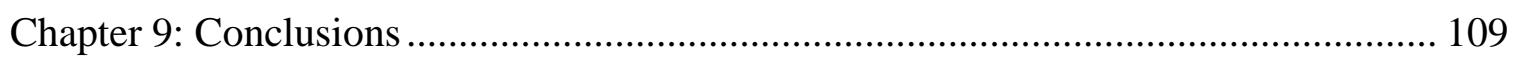

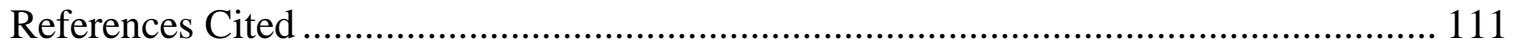

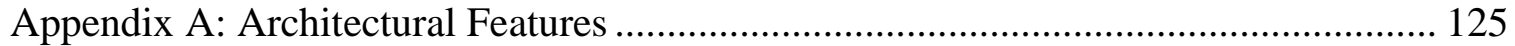

Appendix B: Structural Element and Materials Calculations ..................................... 134 


\section{List of Figures}

Figure 1. Lower Columbia River Region with Meier and Cathlapotle locations. ............. 4

Figure 2. Cathlapotle house outlines with excavation units.......................................... 5

Figure 3. Meier house outline with excavation units.................................................... 6

Figure 4. Profile of trench intersecting Cathlapotle House 1.......................................... 8

Figure 5. Examples of architectural features. .......................................................... 9

Figure 6. Examples of wall trenches in Cathlapotle House 4. ..................................... 10

Figure 7. Idealized plankhouse with architectural elements labeled. ............................ 31

Figure 8. Plankhouse long axis and shirt axis, and roof width and length..................... 32

Figure 9. Architectural features recorded at Meier, including possible features. ........... 40

Figure 10. Architectural features recorded at Cathlapotle House 1, including possible features.

Figure 11. Architectural features recorded at Cathlapotle House 4, including possible features.

Figure 12. Example of incomplete features at Cathlapotle, truncated by both unit walls and other features.

Figure 13. Architectural features flanking compartments, Cathlapotle House 1.

Figure 14. Exterior features at Cathlapotle, (left) location of exterior units with major groups of features, (right) selected clusters of exterior features................................... 46

Figure 15. Upper elevation of architectural features in the west wall, Meier House....... 51

Figure 16. Upper elevation of architectural features in central areas, Meier House........ 52

Figure 17. Upper elevation of architectural features in walls, Cathlapotle House 1...... 53

Figure 18. Upper elevation of architectural features in central areas, Cathlapotle House 1. .

Figure 19. Upper elevation of architectural features in walls, Cathlapotle House 4. ..... 55

Figure 20. Upper elevation of architectural features in central areas, Cathlapotle House 4.

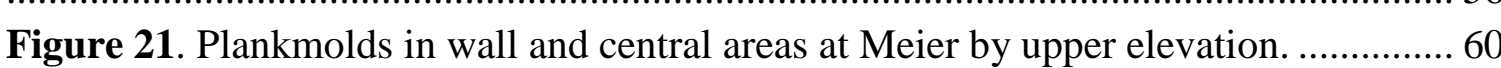

Figure 22. Plankmolds in walls and central area at Cathlapotle House 1 by upper elevation.

Figure 23. Plankmolds in walls and central area at Cathlapotle House 4 by upper elevation.

Figure 24. Distribution of selected features across plankhouse facilities, Meier. .......... 64

Figure 25. Distribution of selected features across plankhouse facilities, Cathlapotle.... 66

Figure 26. Combined posts by size class, Cathlapotle and Meier................................. 69

Figure 27. Plankmolds by size class, Cathlapotle and Meier........................................ 69

Figure 28. Distribution of plank and post feature $(>7 \mathrm{~cm})$ across facilities................... 70

Figure 29. Methods of raising posts and beams..................................................... 74 
Figure 30. Historic vegetation in the Upper Willamette Valley, 1938......................... 80

Figure 31. Cathlapotle historical vegetation based on 1850s T-sheets .......................... 81

Figure 32. Meier historical vegetation based on 1850s T-sheets ................................ 82

Figure 33. Structural features at Meier and Cathlapotle. .......................................... 86 


\section{List of Tables}

Table 1. Facilities at Meier and Cathlapotle. ………..................................................... 7

Table 2. Attribute Data Included in Meier and Cathlapotle Architectural Features GIS. 26

Table 3. Methods of Determining Structural Element Metrics...................................... 32

Table 4. Features Included in GIS Databases. .............................................................. 37

Table 5. Descriptive Statistics for Meier Features with Complete Horizontal

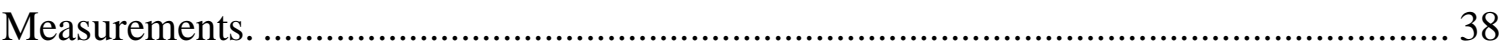

Table 6. Descriptive Statistics for Cathlapotle Features with Complete Horizontal

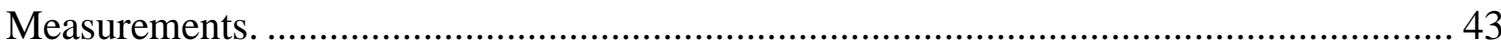

Table 7. Selected Groups of Exterior Features at Cathlapotle. ........................................ 47

Table 8. Vertical and Horizontal Positioning of Architectural Features, Meier. ............. 49

Table 9. Vertical and Horizontal Positioning of Architectural Features, Cathlapotle

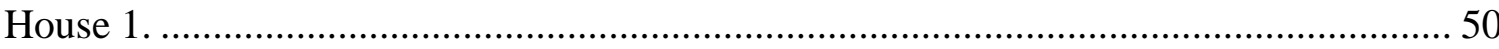

Table 10. Vertical and Horizontal Positioning of Architectural Features, Cathlapotle

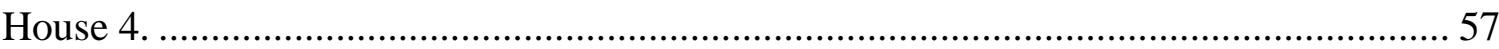

Table 11. Spearman's Rank Order Test for Groups of Plankmolds................................ 59

Table 12. Linear Directional Means for Groups of Plankmolds by Depth. ..................... 59

Table 13. Results of Mann-Whitney Test for Differences in Feature Length and Width

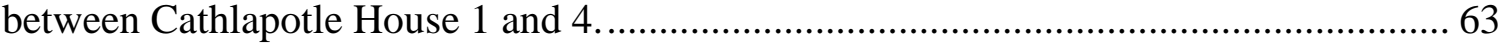

Table 14. Differences in Feature Metrics in Facilities, Meier. (Only Results where $\mathrm{p}<.1$ Included).

Table 15. Differences in Feature Metrics in Facilities, Cathlapotle (Only Results where $\mathrm{p}<.1$ Included).

Table 16. Comparison of Lengths and Widths of Features at Cathlapotle and Meier. .... 68

Table 17. Selected Southern Northwest Coast Plankhouse Architectural Element

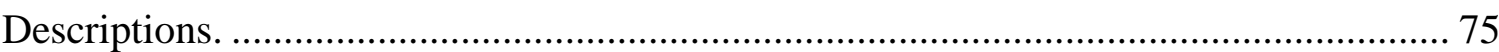

Table 18. Square Meters of Planked Roof, Siding and Floor, Meier and Cathlapotle..... 85

Table 19. Trees Represented in Initial Construction of Houses, Meier and Cathlapotle. 85

Table 20. Hours Required to Fell Trees, Meier and Cathlapotle. .................................... 88

Table 21. Weight of Wood Material Needed for Initial Construction, Meier and Cathlapotle

Table 22. Number of Planks Needed for House Sheathing, Meier and Cathlapotle........ 90

Table 23. Plankhouse Excavated Depth and Estimated Person Days to Excavate, Meier

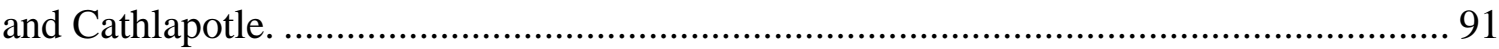

Table 24. Labor Estimates of House Raising, Meier and Cathlapotle............................ 92

Table 25. Person Days Associated with House Construction Tasks................................. 93

Table 26. Total Planking Needs Over House Lifespan, Meier and Cathlapotle.............. 95 
Table 27. Numbers of Trees Needed for Replacement of Planks and Posts over 400 Year

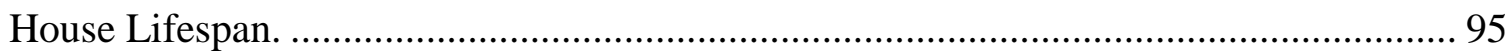




\section{Chapter 1: Introduction}

Plankhouses were at the heart of political, social and economic life for people of the Northwest Coast. Each structure was home to a household group with a distinct identity. Plankhouses were not only dwellings, but served a myriad of functions including storage facilities, ceremonial stages and centers of production. Construction and maintenance of plankhouses, which could stand for hundreds of years and house dozens of generations, entailed major investments of raw material, human effort and social capital. Although the importance of plankhouses on the Northwest Coast is well known, only a few studies have been able to use archaeological data to investigate architecture or to examine labor involved in building and maintaining these structures over their long uselives.

In this thesis, I argue that in addition to the cultural importance of plankhouses within Northwest Coast societies as 'finished products', the actual process of plankhouse production was significant, and can inform our understandings of these groups in various ways. The massive input of labor to construct the dwellings embodied the house founders' economic, social and political power. Hence, sustained labor investment in houses affirmed commitment to the household and displayed the group's continued economic prosperity. Labor activities involved in building and maintaining plankhouses constituted a major ongoing task for household members and so can give us a better understanding of everyday work. Harvest of cedar trees for housing occurred in forests, and so provides an opportunity to investigate activities that transpired outside of villages. Understanding how Indigenous peoples extracted trees from the landscape can also increase knowledge 
of resource management practices. Furthermore, archaeologically visible signatures of plankhouse labor can be used to characterize the organization of other communal work endeavors that are harder to detect from material remains, such as fish, tuber and berry processing.

This thesis focuses on two plankhouse village sites in the Lower Columbia River Region (LCRR) of the southern Northwest Coast, Meier and Cathlapotle. Although structures at the villages are long gone, evidence of materials utilized and house design are found in architectural features recorded during archaeological excavations. I use GIS maps and statistical tests to examine morphological attributes of structural elements and to test prior models of house architecture, repair activities, and physical continuity. I apply these data to develop estimates for the amount of labor involved in constructing and maintaining plankhouses at Meier and Cathlapotle. This includes quantifying materials and time, as well as characterizing the skills and knowledge workers needed for house construction. Throughout this thesis, I address the role of plankhouse architecture in LCRR groups using the framework of household archaeology. I also employ ideas from political economy to consider the broader implications of plankhouse production.

I begin with a description of Meier and Cathlapotle and briefly summarize prior relevant research at these sites (Chapter 2). Chapter 3 discusses political economy and household archaeology and their significance to this project. In Chapter 4, I outline research questions, hypotheses, expectations and methods. Subsequently, I present results associated with seven hypotheses designed to investigate plankhouse structural features and architecture at Meier and Cathlapotle (Chapter 5). I then briefly digress from results 
to review Northwest Coast plankhouse building and repair processes (Chapter 6), drawing from other archaeological studies, historical documents and ethnographies. I also outline pertinent information concerning western redcedar ecology, distribution and characteristics. Information from this chapter is then applied to data from Cathlapotle and Meier to quantify and characterize labor tasks associated with household construction and maintenance (Chapter 7). In Chapter 8, I consider plankhouse architecture in relation to LCRR households and situate plankhouse production within socioeconomic aspects of these groups, and also discuss potential directions for future research. In Chapter 9, I conclude by arguing that labor involved in the production of plankhouses is deeply intertwined with socioeconomic aspects and continuity of LCRR households. Two appendices are included: Appendix A, which details architectural features in the Meier and Cathlapotle databases, and Appendix B, which provides further information regarding calculations of raw materials used in plankhouse construction. 


\section{Chapter 2: Meier and Cathlapotle}

\section{$\underline{\text { Site Contexts and Excavation Backgrounds }}$}

Meier (35CO5) and Cathlapotle (45CL1) are located in what has been termed the Wapato Valley, an area of the LCRR (Figure 1) that was densely inhabited by around 8,000 people in the early 1800s (Ames et al. 1999). Groups in this region lived in winter villages and traveled further afield in the summers for resource collection. Food was obtained by fishing, collecting plants, and hunting. Plants were also important for a variety of technologies.

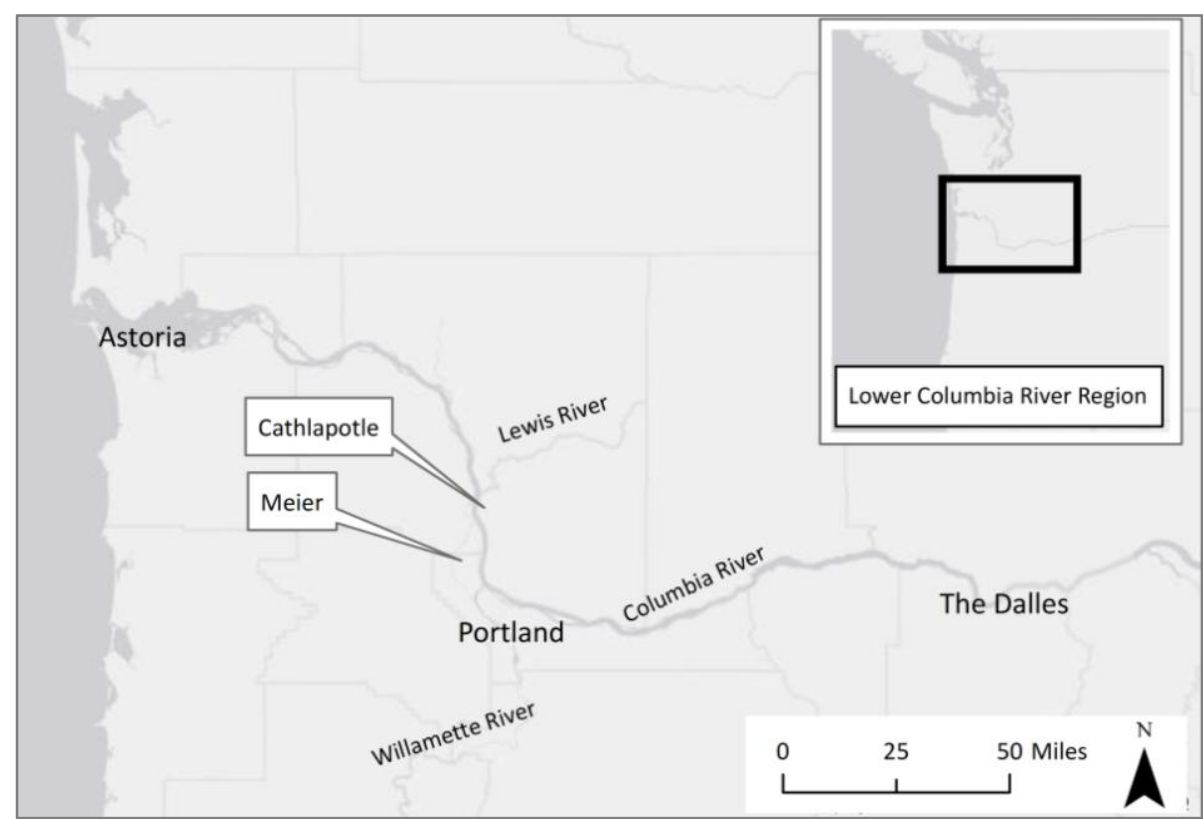

Figure 1. Lower Columbia River Region with Meier and Cathlapotle locations.

Cathlapotle is located directly east of the Columbia River on what is now the Ridgefield National Wildlife Refuge. Cathlapotle was a large, multi-house site with an estimated population of 700 to 800 people (Ames 2008) (Figure 2). The village was occupied by Chinookan speakers and may have periodically increased in population with influxes of people from neighboring communities (Boyd 2011:177). Lewis and Clark, 
who visited the site in the fall of 1805 and again in the spring of 1806, describe Cathlapotle as a busy trading village containing 14 houses (Moulton 1990). Several historical accounts document the village during the protocontact era, where many changes in village demography and subsistence practices occurred (Boyd 2011).

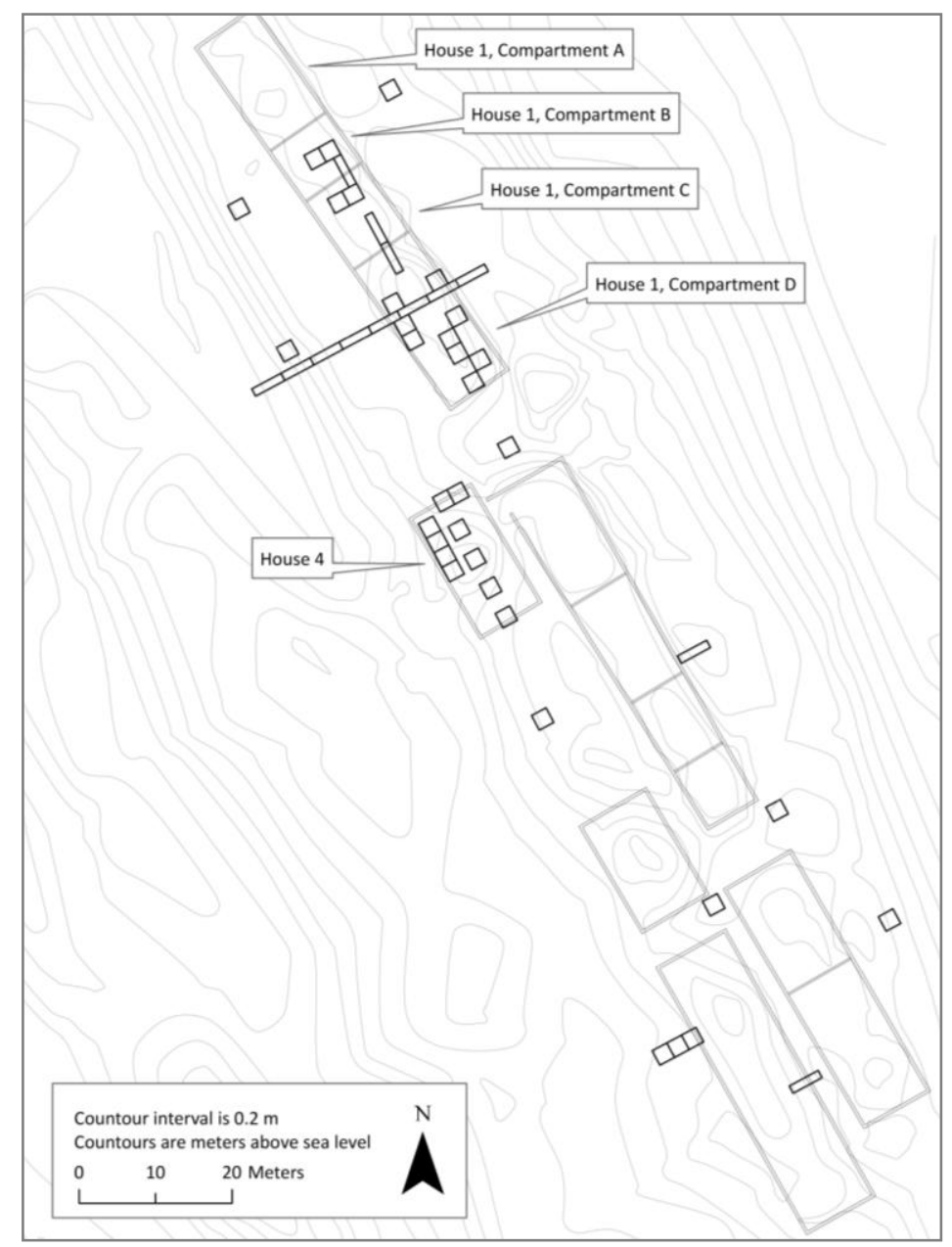

Figure 2. Cathlapotle house outlines with excavation units.

Surveying, auguring and test excavations occurred at Cathlapotle from 19911993, and more extensive excavations were conducted by Portland State University field schools from 1994-1996 (Ames et al. 1999:23-34). Radiocarbon dating and historical documents demonstrate that occupation at Cathlapotle extended from approximately A.D. 
1400 to 1832 (Ames and Sobel 2009). Excavation focused on two houses at the site:

House 1 , which measured 65.8 by 10 meters, and House 4, which measured 13.2 by $10 \mathrm{~m}$.

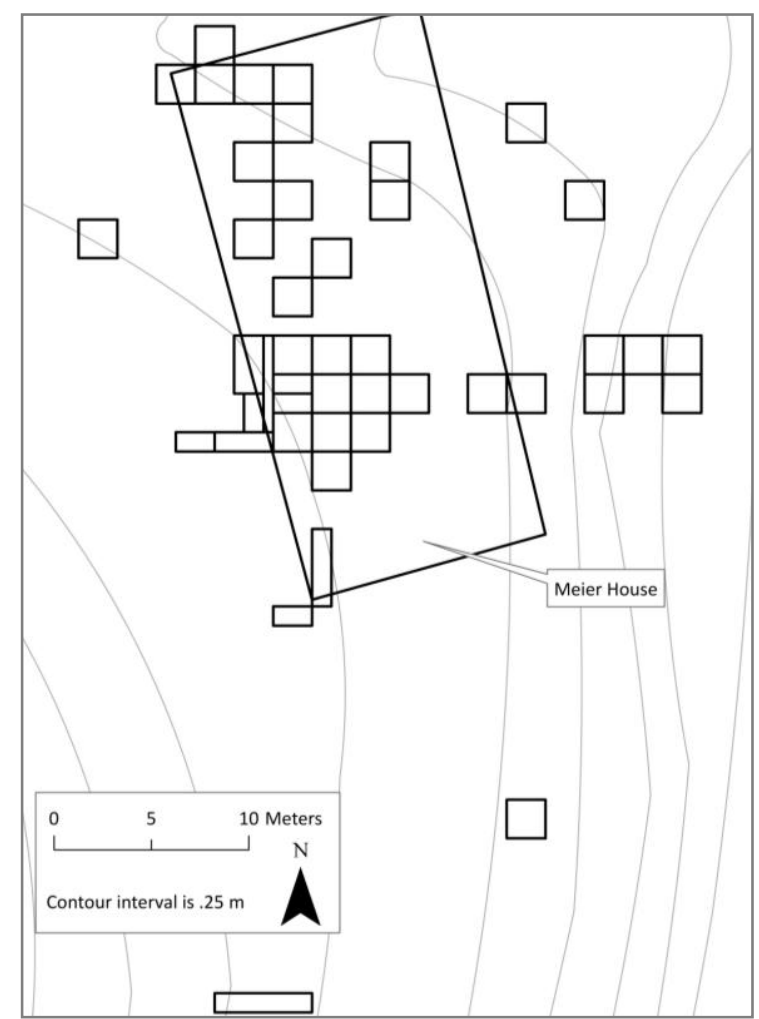

Figure 3. Meier house outline with excavation units.

Meier is situated near the town of Scappoose, Oregon. The single-house site lies two meters above a creek on a gravel terrace approximately two kilometers west of the Columbia River (Ames et al. 1992). Unlike Cathlapotle, Meier was not recorded by early explorers. Meier was likely less of a trading hub in precontact times because of its positioning further from important rivers, although involvement may have increased during the postcontact fur trade (Fuld 2012). The first small-scale archaeological investigations at Meier were conducted by Pettigrew (1981) and Ellis (n.d). The site was more intensively excavated from 1987-1991 by Portland State University (Ames et al. 
1992) (Figure 3). Radiocarbon dating places occupation of Meier from around A.D. 1400

to 1820 (Ames 1996). The Meier House was approximately 30 by $14 \mathrm{~m}$.

Houses at each site are divided into facilities that served as analytic units, which

are outlined in Table 1 (Smith 2006). Facilities are the same at both sites with two

exceptions: bench and cellar facilities were combined at Cathlapotle and the berm facility

was not used at Meier (this facility was either always absent or destroyed by plowing).

Table 1. Facilities at Meier and Cathlapotle.

\begin{tabular}{|c|c|c|c|c|}
\hline Facility & Description & Location & Associated Elements & Feature Correlates \\
\hline Wall & $\begin{array}{l}\text { Walls of house } \\
\text { comprised of vertical } \\
\text { planks }\end{array}$ & $\begin{array}{l}\text { Surrounding } \\
\text { dwelling }\end{array}$ & $\begin{array}{l}\text { Wall planks, eave } \\
\text { beam support posts, } \\
\text { corner posts, rocks }\end{array}$ & $\begin{array}{l}\text { Wall trenches, } \\
\text { plankmolds, postmolds, } \\
\text { postholes }\end{array}$ \\
\hline Bench & Sleeping and storage & $\begin{array}{l}\text { Ringing interior } \\
\text { of house }\end{array}$ & $\begin{array}{l}\text { Post and plank } \\
\text { bench structures }\end{array}$ & $\begin{array}{l}\text { Small plankmolds, } \\
\text { postholes and postmolds }\end{array}$ \\
\hline Hearth & $\begin{array}{l}\text { Cooking fires, space } \\
\text { for household } \\
\text { activities }\end{array}$ & $\begin{array}{l}\text { Center of house, } \\
\text { parallel to long } \\
\text { axis }\end{array}$ & $\begin{array}{l}\text { Hearth boxes, } \\
\text { drying racks, ridge } \\
\text { beam supports }\end{array}$ & $\begin{array}{l}\text { Ash lenses, plankmolds, } \\
\text { small postholes and } \\
\text { postmolds }\end{array}$ \\
\hline Cellar & $\begin{array}{l}\text { Excavated pits for } \\
\text { storage }\end{array}$ & $\begin{array}{l}\text { Cathlapotle: } \\
\text { under benches. } \\
\text { Meier: between } \\
\text { hearths and } \\
\text { benches }\end{array}$ & $\begin{array}{l}\text { Storage pits, } \\
\text { sometimes lined } \\
\text { with clay or planks }\end{array}$ & Pits, small plankmolds \\
\hline Yard & $\begin{array}{l}\text { House exteriors, used } \\
\text { for activities such as } \\
\text { food processing }\end{array}$ & Outside house & $\begin{array}{l}\text { Drying racks, earth } \\
\text { ovens }\end{array}$ & $\begin{array}{l}\text { Small plankmolds, } \\
\text { postholes, postmolds and } \\
\text { earth ovens }\end{array}$ \\
\hline Toft & $\begin{array}{l}\text { Areas of debris build } \\
\text { up immediately } \\
\text { outside the house }\end{array}$ & $\begin{array}{l}\text { Outside walls } \\
\text { under eaves, on } \\
\text { top of berms }\end{array}$ & Rubbish & Debris concentrations \\
\hline Berm & $\begin{array}{l}\text { Ridges created by } \\
\text { disposal of house fill } \\
\text { and excavation spoils } \\
\text { during construction } \\
\text { and maintenance }\end{array}$ & $\begin{array}{l}\text { Surrounding } \\
\text { depressions }\end{array}$ & Rubbish, spoil soil & Debris concentrations \\
\hline $\begin{array}{l}\text { Sheet } \\
\text { Midden }\end{array}$ & $\begin{array}{l}\text { Rubbish disposal, } \\
\text { sometimes processing } \\
\text { activities }\end{array}$ & House exterior & $\begin{array}{l}\text { Rubbish and } \\
\text { accumulated yard } \\
\text { debris from exterior } \\
\text { activities }\end{array}$ & $\begin{array}{l}\text { Small postmolds and } \\
\text { plankmolds; thin, flat } \\
\text { sediment strata and } \\
\text { lenses }\end{array}$ \\
\hline Midden & Rubbish disposal & House exterior & Rubbish deposits & Deep debris mounds \\
\hline
\end{tabular}

\section{$\underline{\text { Site Formation Processes }}$}

Numerous processes contributed to site formation at Meier and Cathlapotle.

Schiffer (1972) draws a distinction between activities that occur during site occupation 
(systemic context) and after site occupation (archaeological context). Smith (2008)

investigates both systemic and archaeological site formation processes at Meier and Cathlapotle, concluding that ongoing cleaning and maintenance by house occupants was a major systemic site formation process. Continuous occupation at the sites for 400 years necessitated replacement of posts and planks, as well as reexcavation, filling and cleaning of subterranean storage features. This resulted in complex stratification, with intrusive younger features often obliterating sections of older features (Figure 4).

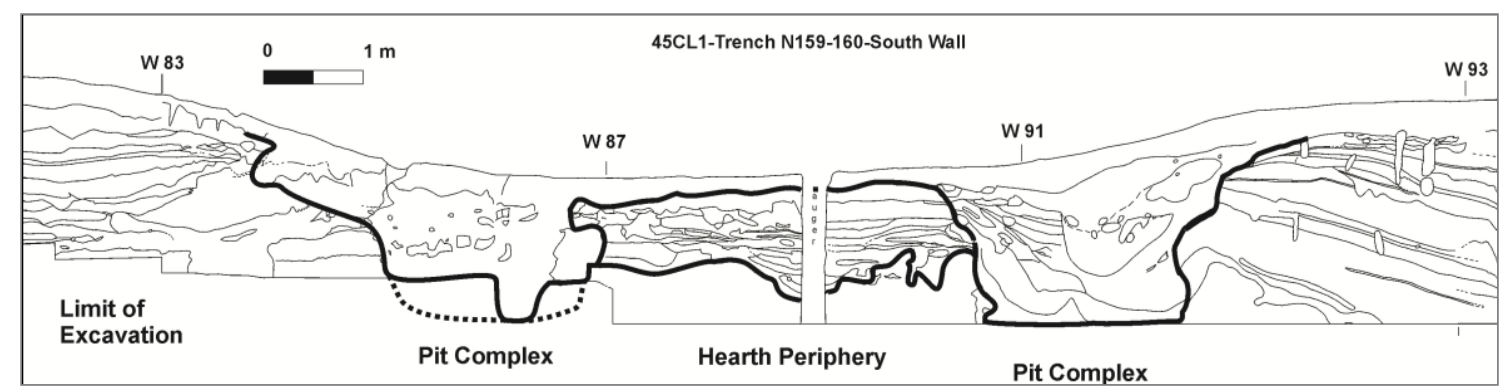

Figure 4. Profile of trench intersecting Cathlapotle House 1 (N159-160/W83-93) illustrating complex stratification of house floors, hearths, walls and pits (figure based on Ames et al. 1999, Figure 11).

Site formation processes in the archaeological context that affect architectural features include rot and decay, lumber scavenging, bioturbation and plowing. Looting also occurred at both sites, although impact at Cathlapotle was minimal. At Meier, the eastern portion of the site was heavily looted. In addition to modern looting, architectural elements may have been scavenged and removed from the sites by early settlers. Other significant impacts to sites that likely occurred in the archaeological context resulted from natural forces, including trampling, decay, decomposition, bioturbation, and floods.

As this thesis is focused on architectural features, special attention to formation processes associated with these features is warranted. Figure 5 illustrates plank and post features encountered during excavation. Plankmolds and postmolds are formed by posts 

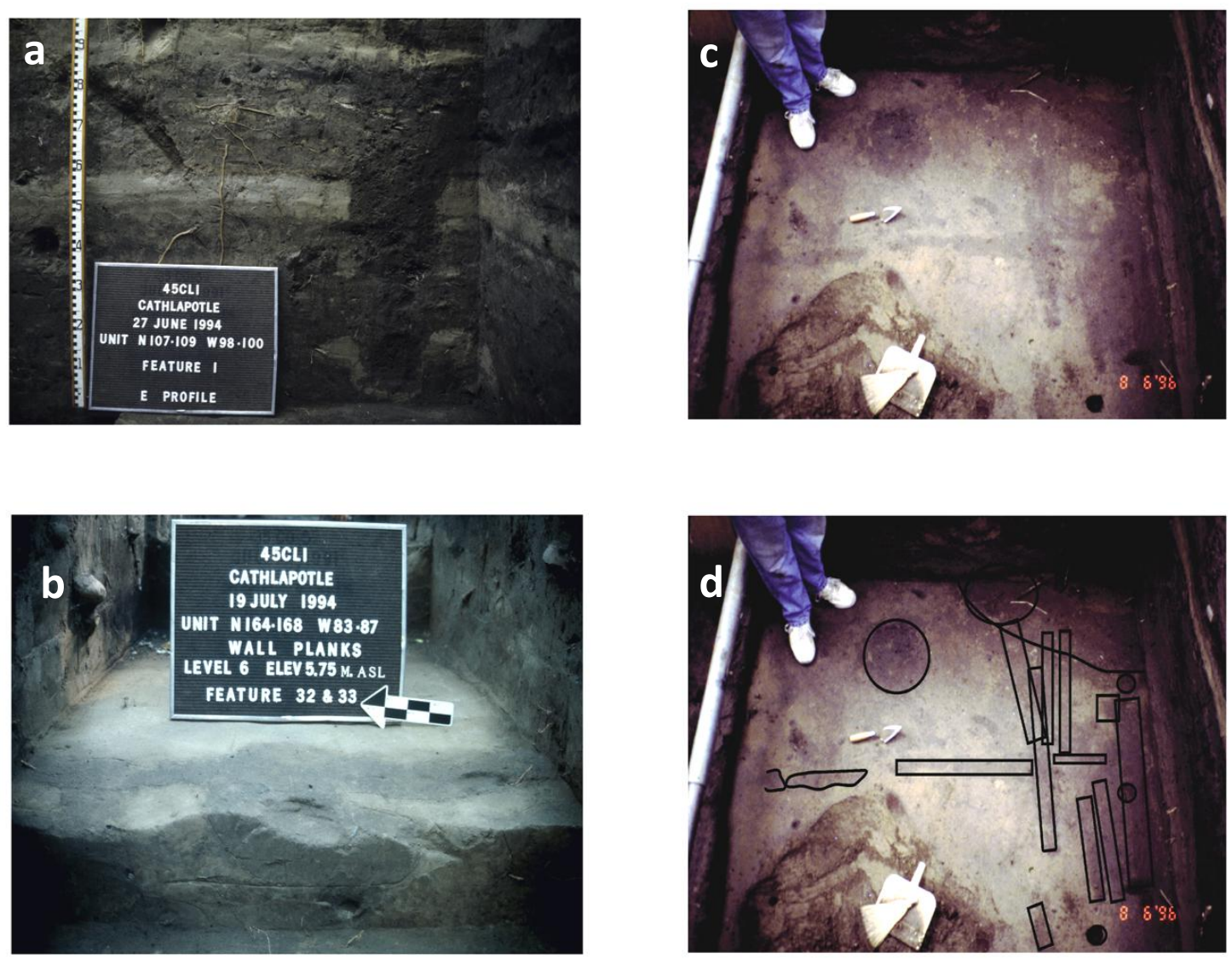

Figure 5. Examples of architectural features: (a) postmold in profile (b) wall plankmold in plan and profile (c) plankmolds and postmolds visible on unit floor (d) plankmolds and post features outlined (figure drafted by Kenneth Ames).

and planks that decayed in situ and are distinguished by stains of decomposed organic material. Postholes are the excavated hole where a post was placed. Postholes were sometimes backfilled in the systemic context after post removal, and may contain artifacts (Verhoeven 2010). Alternatively, postholes can be naturally filled after site abandonment. Wall trenches are the excavated areas where planks were set to form house walls, and are often associated with complex, continuous distributions of plankmolds (Figure 6). Attributes of architectural features detected during archaeological excavation sometimes reveal impacts of systemic site formation processes (Barker 2005:4). Features 
that show signs of rocking indicate deliberate removal of posts or planks. Charring around the rims of features and pieces of charred wood reflects burning of a structure.

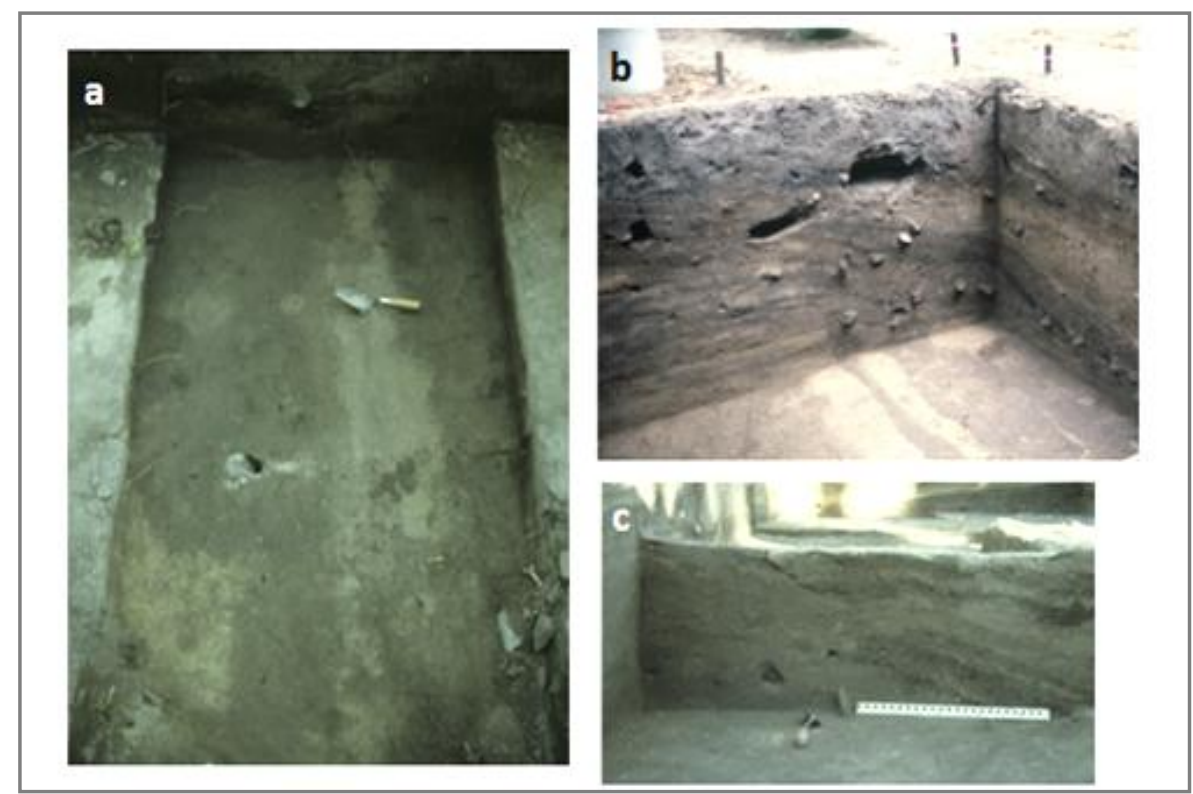

Figure 6. Examples of wall trenches in Cathlapotle House 4: (a) West wall beginning to emerge, wall trench is the dark stain left of the trowel. (b) Wall trench of the north wall in plan and profile. One trench is a plank wide and to its right is a larger trench. Fill in the trench is visible above it and merges into storage pits. (c) West wall in profile with sand floors terminating against the wall (figure drafted by Ken Ames).

During excavation, variation in color between features and the surrounding soil matrix resulted in relatively easy detection of architectural features (see Figures 5 and 6). Investigations at Cathlapotle benefit from exceptional feature preservation and stratigraphic integrity, partially resulting from repeated rapid alluvial deposition (Ames et al. 1999:81; Hodges and Smith 2002). At Meier, plowing obscured many remnants of shallow architectural features (Ames et al. 1992), consequently most features are related to the more-deeply buried house frame.

House depressions were affected by numerous systemic and archaeological formation processes. Villagers used natural topographic features formed by the meandering river as the basis of depressions, which were further excavated with the 
spoils added to natural crests. Depressions were accentuated by debris accumulation at the sides of houses during occupation, resulting in a sharper difference between exteriors and excavated interiors. At Cathlapotle, the west and east sides of houses are distinguished by berms composed of especially pronounced accumulations of house fill and debris, heightened by the accumulation of sediments from numerous minor flood events (Hodges and Smith 2002). Cathlapotle House Depressions 1, 2, 3 and likely 6 were divided by low ridges perpendicular to their long axis. Excavation revealed that these ridges contained plankmolds, indicating that these houses were subdivided into separate compartments (Ames et al. 1999:37). Ridges in Depression 1 (the correlate of House 1) were separated by compartments labeled A-D (Figure 2).

\section{Prior House and Household Research}

Ethnographies and historical documents provide valuable information concerning LCRR houses. Although plankhouses throughout the Northwest Coast shared many similarities, elements of structures such as roof style and interior layout varied (Gahr et al. 2006; Suttles 1992; Vastokas 1966). Hajda's (1994) compilation of ethnohistoric sources in the LCRR demonstrates variability in village layout and house size, but similar building styles. Large, semi-subterranean, post-and-beam plankhouses were constructed from western redcedar (Thuja plicata), had gabled roofs and had vertical plank walls. Multiple large hearths were located in central area of the houses, walls were lined with benches for sleeping and storage, and an oval hole served as the house entrance. Interiors were segmented according to rank, with the portion near the door often occupied by slaves or low status peoples. 
Excavations at Meier and Cathlapotle confirm much of this ethnographic information and allow for elaboration. The floor of Meier was covered with planks for at least some of its existence (Ames et al. 1992). The discovery of high status goods in the south of Cathlapotle House 1 (Compartment D) and the northern section of the Meier House indicate that these areas were inhabited by elites (Ames 2008).

Spatial patterns of artifacts from Meier and Cathlapotle inform understandings of households in the LCRR. By analyzing distribution of the prestige good of obsidian within households, Sobel (2004) demonstrates that subtle status differences existed between houses in the LCRR. Using distribution of artifacts types and use wear within the Meier and Cathlapotle houses, Smith (2006) shows that social rank influenced degree of participation in various economic activities. Higher ranked households or elites within houses were more likely to engage in tasks such as stone tool manufacture, while lower ranked people were more likely to engage in large-scale fishing and hide scraping. These studies provide evidence of differential access to materials and specialization both within and between LCRR households.

Hearth and pit features at Meier and Cathlapotle are well understood. Large, central hearths and massive complexes of storage pits were noted at each site (Ames et al. 2008; Bulter 2007; Gardner-O'Kearney 2010). At Meier, pits were located in the central area of the house adjacent to hearths, while at Cathlapotle pits lined house interiors. There are interesting differences between storage pits at Meier and Cathlapotle, with pits at Meier significantly larger and more varied in form (Butler 2007:67,143). Research into hearths indicates that at Meier, these features differed in morphology and content 
between status areas of the house, a pattern followed to a lesser degree at Cathlapotle (Gardner-O'Kearny 2010). These studies suggest possible differences between interior use at each site, and between people of different ranks within households.

Several studies explore costs of building the Meier and Cathlapotle houses in terms of materials and labor. At Meier, construction and maintenance required a tremendous amount of raw material (Ames et al. 1992). Significant effort was also expended on building repair, many elements show evidence of replacement a minimum of five times (Ames et al. 1992). Labor expenditures to construct houses were enormous, Gahr (2006) calculates that 20-50 times the population of the Meier community was required for house raisings.

Architectural features have been used to infer sociopolitical aspects of the communities. Ames (1996) outlines the significance of architecture in cultural reproduction and transmission at Meier. Similarly, Smith (2006) connects high levels of structural stability at Meier over the house's 400 year uselife with continuity in social structure. However, the Meier House may have shifted slightly approximately midway through house occupation (evidenced by a 10-15 degree change in orientation of ridge beam supports), the house may have once been entirely rebuilt, and the north wall of the house may have been moved south (Ames et al. 1992; Smith 2006:241). Other indications of changes in interior architecture are evident from plankmolds noted under hearths (Gardner-O'Kearny 2010). These studies provide an excellent basis for further exploration of plankhouse architecture, materials and labor at the two sites. 


\section{Chapter 3: Theoretical Orientation}

\section{$\underline{\text { Political Economy }}$}

Contemporary political economy is highly influenced by the writings of Karl Marx, who in his critique of previous economic theory argued that economies should not be analyzed in isolation, but must be considered within a broader context of social relations (Giddens 1973:10). Marx also stressed that capitalism and private property was only one of many possible economic formations. Although political economy has developed greatly in the past 150 years, these two overarching points are still salient. Among the many current definitions of political economy, the one I find most useful is Saitta's (2012): “the various and complex ways that humans produce and distribute social labor in specific historical circumstances, and negotiate the cultural conditions that sustain such relationships." In this section, I tease this statement apart to discuss how political economy informs this project. I focus on three aspects of this definition: production, social labor, and "cultural conditions that sustain relationships".

Following from its Marxist roots, emphasis on production is one of the defining aspects of archaeological studies of political economy (Robotham 2012, Trigger 1993). Questions addressed by these studies include: Who is doing the producing? Who is organizing or controlling production? Who owns the goods that are produced? Importantly, contemporary political economy diverges from traditional Marxism in that mode of production is not used to group societies into static evolutionary categories. Instead, relations of production are examined to understand the contingent cultural development of each group. 
Closely aligned with production is the concept of social labor. One of Marx's most enduring arguments is that economics cannot be considered without regard to sociopolitical factors (Giddens 1971:10). Labor is seen not merely as work, but also as connections and relationships among people (Cobb 1993). This social definition of labor highlights that economic, social and political aspects of society are deeply interconnected. This point has been employed to link labor and production with aspects of society traditionally not viewed as economic, such as ideology (Wolf 1999), gender (Cobb 1993) and knowledge (Williams 1977).

Saitta's definition of political economy also emphasizes the "cultural conditions that sustain such relationships". In contrast to some other theories, political economy emphasizes that conditions within societies are not self-sustaining, but are constantly being maintained, reproduced, renewed and changed. Material culture is active and often plays a role in this process, not only because it "physically organizes space and action", but also because objects take on social meaning as they are created by people through labor (McGuire 1992:103). Thus, archaeological studies focusing on political economy often examine how social conditions are maintained or changed within specific societies through material culture.

These three elements of political economy - production, social labor, and active sustaining of conditions - inform this project. Architecture is an extremely important aspect of material culture in shaping and reproducing social elements for two reasons. First, buildings are highly visible and permanent compared to other aspects of material culture (Nielson 1995). Buildings embody social and symbolic capital in materials used 
for construction and decoration, and in labor expended on the structure. Second, buildings are part of the day-to-day, domestic life of all people within a society - "as nondiscursive phenomenon, architecture is crucial to the reproduction of social practice because it provides part of the mundane, everyday reality" (McGuire 1992:203). Importantly, relations of labor involved in constructing and maintaining plankhouses were qualitatively different than the alienated labor involved in capitalism that has been critiqued by Marx and other political economists. The sociopolitical importance of collective production of dwellings is emphasized in Rapoport's comprehensive study of worldwide structural forms (1969:107), where house building is characterized as a "complex, multiple activity... with collective work as its essence." Unlike in capitalist societies, labor involved in plankhouses was not hidden and mystified, but was overt and emphasized in the product of the labor. The transparent social quality of the labor is important, as plankhouses served as constant testaments of this expenditure. Plankhouses embodied not only the social capital of the household and its leaders, but just as importantly, served as a reminder of corporate identity present throughout continuing generations.

Household Archaeology

Broadly speaking, households are defined as co-residential groups that form the basic economic, social and political unit of community life (Wilk and Rathje 1982). Archaeologists employ data gathered from excavations, ethnoarchaeology, and ethnography to study households (Steadman 1996). Although archaeological house remains should not be studied as the simple material correlates of households, the history 
of household archaeology demonstrates that analysis of house structures can provide valuable insight into households.

Household archaeology coalesced as a subdiscipline in the 1980s. Initially, much household research focused on the adaptive function of households. In classic papers, Wilk and Rathje (1982) argue that households increase efficiency by enabling collective engagement in production and distribution, while Hayden and Cannon (1982) postulate that corporate groups allow community stability. A major goal during this time was general theory building to enable information about households to be extrapolated from material remains of houses. For example, McGuire and Schiffer (1983) explore symbolic and utilitarian elements of architectural design, asserting that house structure is a product of both environmental and social constraints. Rathje and McGuire (1982) examine how domestic architecture can be correlated with degree of access to basic resources among Maya households.

Early household studies concentrated not only on characterizing individual households, but also on variability among household groups both within and between settlements. Stanish (1989) classifies characteristics of exterior house architecture as a method of differentiating ethnicities in precontact villages in the Central Andes. Bawden (1982) examines room size of houses in four different areas of a Moche village to tease apart socioeconomic variability of households. In a study of a late neolithic site in northeastern Yugoslavia, Tringham (1991) researches how decisions made within households can be reflected in small scale architectural changes that differ between communities. Studies such as these enable comparisons between household groups. 
Ethnoarchaeology is important in building theory and methodology to interpret architecture and household artifacts. By observing contemporary cultures, researchers can detect relationships between social structure and architecture that can be applied to archaeological data. Using examples from ethnographies and ethnoarchaeology fieldwork, Kent (1990) argues that sociopolitical complexity is marked by increasing spatial segmentation within houses. Other researchers use ethnographic data to assert that higher quality construction is associated with household permanence (McGuire and Schiffer 1983), and that larger house size is linked with wealth (Netting 1982). However, assumptions cannot be generalized to all cultures (Arnold and Ford 1980). In fact, ethnographies demonstrate the complexity of relating households to larger communities or economies (Nash 2009:221).

Archaeologists also study ancient households by investigating labor involved in building activities. Abrams (1994) presents a comprehensive analysis of work involved in house construction at the Maya site of Copan. Carmean (1991) quantifies labor investment in house structures to study the development of land ownership patterns on the Yucatan Peninsula. Other researchers examine labor and materials involved in household rebuilding and repairs, linking continued investment in maintaining house appearance to social reproduction and stability (Hally 2008:308; van Gijseghem 2001:268).

Contemporary household archaeologists are much less concerned with functionalist approaches than in the beginning of the subdiscipline. Instead, researchers are largely interested in two different (although not incommensurable) research focuses: 
individuals and broad processes. Many archaeologists emphasize the capacity of domestic structures to provide information concerning commoners in complex societies where much research often centers on monumental architecture and rituals related to elites (Fleisher and LaViolette 1999; van Gijseghem 2001; Wendt 2005). Other studies explore inequality and use house architecture to investigate lives of low status people, women or slaves (Hagstrum 2001; Hendon 1996; Pauketat and Alt 2005). This research also serves as a reminder that households are not cohesive wholes, but are comprised of individuals with different goals according to age, gender and class (Barlett 1989).

Other archaeologists focus on the role of households in large societal changes, using developments in house form or household activities to study sociopolitical shifts. For example, Kolb (1997) charts differences in labor required for structures built over an 800 year period in a Hawaiian community to explore changes in social organization, while Saitta (1997) uses data on labor involved in Chacoan architecture to examine sociopolitical change. The combination of these two focuses - individuals in households, and the role of households in large changes - allow archaeologists to develop ways of examining developments on both fine and coarse scales.

Household archaeology provides the theoretical underpinning of this study, which examines architecture of dwellings and characterizes household labor in production of plankhouses. The household is the basic unit of analysis for this project, and the fundamental assumption of household archaeology - that material house remains can be used to study households - is elemental in the research design. Household archaeology 
provides methods of using archaeological data to make inferences about household groups on the LCRR.

\section{Household Archaeology on the Northwest Coast}

Plankhouses and the household groups they sheltered have been important elements of Northwest Coast groups since at least 3000 B.P. (Coupland 1985; Hayden 1997), and perhaps much earlier (Martindale et al. 2009). Development of the household social group is linked to the evolution of key elements of Northwest Coast societies including resource intensification, storage and inequality (Ames 2003).

Although approximately twenty plankhouse village sites in the LCRR are reported in the ethnohistoric literature, only three sites other than Meier and Cathlapotle have undergone extensive excavation (Ames and Sobel 2013). Middle Village, located at the mouth of the Columbia, contains the remains of at least five approximately 8 by $10 \mathrm{~m}$ plankhouses (Wilson 2009). Similarly to houses at Meier and Cathlapotle, these were post and beam structures with vertical wall planks and interiors segmented into hearth and bench areas. This protocontact site likely represents a summer settlement focused on trade. Broken Tops, another probable summer settlement, is located around the confluence of the Sandy and Columbia Rivers and contains the remains of several small ( 9 by $8 \mathrm{~m}$ ) dwellings (Ellis 2006). The other plankhouse village in the LCRR subject to intensive excavation is Clahclellah, which was roughly contemporaneous with Meier and Cathlapotle but was located approximately $70 \mathrm{~km}$ upstream on the Columbia (Sobel 2004). The eight or more plankhouses at this village were gable-roofed with vertical wall 
planks, central hearths and planked floors. This information mirrors Hajda's (1994) characterization of LCRR plankhouse architecture based on ethnohistoric documents. Intensive excavation of plankhouses in other areas of the Northwest Coast has enabled researchers to examine sociopolitical aspects of households. In coastal British Columbia, Lepofsky et al. (2000) use archaeological data on shifts and stasis in house form and village layout as proxies for social identity. Other researchers have employed spatial data from plankhouse interior organization to investigate communal activities within household groups (Coupland et al. 2009; Hoffman 1999) or to link household size with status (Coupland 1985).

Other studies focus on production of subsistence and technological goods to consider the social implications of household economies. Ames $(1995,2008)$ considers how specialization, resource control and social organization influence the productive capacity of households. Similar to Smith's (2006) findings in the LCRR, Grier (2001) demonstrates that rank influenced degree of participation in different production activities at a village in southwestern British Columbia. These studies demonstrate that archaeological information regarding house form can provide valuable information regarding dynamics of Northwest Coast households. 


\section{Chapter 4: Research Design}

This thesis uses architectural features at Meier and Cathlapotle to explore two main research aims. The first aim is to examine the construction and maintenance history of plankhouses at the two sites. I use information from architectural features to reconstruct plankhouses from initial building to repairs over subsequent generations, and to test previously proposed models concerning plankhouse structure and continuity at each site. The second aim is to apply information from construction history to characterize and quantify the labor and materials involved in building and maintaining plankhouses.

\section{$\underline{\text { Research Questions and Hypotheses }}$}

\section{Plankhouse Construction and Maintenance History}

Seven research questions were operationalized with hypotheses and archaeological expectations to address the first aim of this project.

\section{(1) The Cathlapotle House 1 interior was compartmentalized, House 4 and the Meier}

House were not. Previous field models posit that Cathlapotle House 1 was compartmented while the Meier House and Cathlapotle House 4 had open interiors (Ames et al. 1992; Ames et al. 1999:46). If so, I would expect large and medium postholes, postmolds and plankmolds to be located in parallel lines bisecting the house interior at Cathlapotle House 1, but not at the Meier House or Cathlapotle House 4. (2) Substantial structures were located outside houses. Some significant architectural features were reported exterior to houses at Cathlapotle (Ames et al. 1999:42,49) and Meier (Ames et al. 1991). Historical documents on the Northwest Coast sometimes note 
that ephemeral structures were located outside houses (see Stewart 1984:73-75). If substantial structures were located outside of houses, clusters of patterned architectural features outside of house depressions would be expected.

(3) Placement of structural elements was consistent through time. Structural elements replaced in similar locations over time would indicate continuity in plankhouse appearance. Models developed during excavations posit that replacement of architectural features was common, but that house layout remained stable over time (Smith 2006). If structural element replacement was frequent and consistent, I would expect to see vertically and horizontally clustered similar features, as these elements would overlap if they were in place at the same time.

(4) Plankhouse orientation was consistent through time. As discussed above, house appearance at both sites is thought to be relatively steady. Stability in house orientation is an indication of structural continuity over time. Orientation of plankmolds can be used as a proxy for house orientation. If house orientation was stable over time, I would expect to see no major correlations between plank orientation and depth. Vertical groupings of planks with orientations deviating from the norm would indicate a broad shift in plankhouse orientation.

(5) Similar structural elements were used in Cathlapotle House 1 and 4, and in Compartments B-D of House 1. Although the two Cathlapotle houses vary in size and status, field observations indicate they are architecturally similar (Sobel 2004:567). If structural elements are similar between houses and compartments, I would expect to see 
no significant differences in maximum length or width when feature classes are compared between the two sites.

(6) Structural elements differ between facilities. Previous models divided houses into architectural facilities reflecting spatial function (see Table 1). Differences in architectural features between facilities would indicate these designations reflecting interior house use are quantifiably distinct. If structural elements differ between sites, I would expect to see differences in feature size and distribution between facilities. (7) Similar structural elements were used at Meier and Cathlapotle. Architectural information can increase understanding of differences and similarities between the villages. Although plankhouse architecture at the two sites seems comparable, there are intriguing differences despite their contemporaneousness and close proximity (e.g. Davis 2012; Fuld 2012). If architecture was comparable at the two sites, I would expect features to be similarly sized and for feature distribution to be alike.

\section{Plankhouse Construction and Maintenance Costs}

An important goal of this study is to articulate how activities related to house building and upkeep contributed to households being sustained over many generations. Calculations of labor involved in house raisings by Gahr (2006) demonstrate that many person days were required for this aspect of house construction. I continue assessments of labor involved in plankhouses by characterizing and quantifying tasks involved in procuring materials for houses, preparing for building, construction, and maintenance. I do so by addressing the following questions: 
- How many trees were required for house construction and repair? Prior work at Meier and Cathlapotle show that a large amount of lumber was used in these building and maintaining these structures (see Ames et al. 1992; Ames 1996). In addressing this question, I seek to expand estimates of wood required for houses by using precise estimates of house surface area and structural element size derived from architectural data. - What tasks were associated with plankhouse construction and repair, and how many person days did this work entail? In investigating this question, I aim develop a production sequence for plankhouse construction in the LCRR that attempts to consider all aspects of preparation, construction, and maintenance within a social context. - How often would structural elements need to be replaced? In examining this question, I attempt to determine replacement rates of structural elements to allow estimates of wood needed for house maintenance, and also to assess labor required to procure these trees.

\section{Methods}

Initial work for this thesis consisted of digitizing architectural features recorded during excavation in ESRI ArcMap10. Each feature form from the two sites was examined. If the feature was architectural, it was digitized in the greatest detail possible. Detail in feature digitization was dependent on the scale of the original map and completeness of notes. GIS databases were checked against feature catalogs to ensure that each architectural feature was included. Numerous attribute fields were populated, data were extrapolated directly from feature forms when possible (Table 2). When information was clearly incorrect (e.g. horizontal measurements outside of the unit address), a note was made on the digital catalog describing the nature of the error and the 
changes were made in the GIS. When attribute data were missing from the feature form, an effort was made to locate the information in level forms or field notebooks. Files associated with this project were maintained in a manner that will maximize ease of use for future studies.

Table 2. Attribute Data Included in Meier and Cathlapotle Architectural Features GIS.

\begin{tabular}{|c|c|}
\hline Attribute & Description \\
\hline Associated Features & As noted during excavation, any associated features \\
\hline Associated Specimens & Specimens collected from the feature during excavation \\
\hline Beginning Elevation* & Depth where the feature was first noted \\
\hline Beginning Elevation from & Depth where feature was first noted, with any site datum \\
\hline Datum* & corrections \\
\hline Comments & $\begin{array}{l}\text { Additional comments made in the field or noted while imputing the } \\
\text { feature into GIS }\end{array}$ \\
\hline Complete & $\begin{array}{l}\text { Whether the feature was complete, or was truncated by another } \\
\text { feature or unit boundary }\end{array}$ \\
\hline Date & Date the feature was excavated \\
\hline Ending Elevation* & Depth where feature was last noted \\
\hline Ending Elevation from Datum* & Depth where feature was last noted, with any site datum corrections \\
\hline Feature Class & Classification of feature (plankmold, posthole, etc.) \\
\hline Feature Number & Feature number assigned during excavation \\
\hline Fill & Color and texture of feature matrix \\
\hline Horizontal Location & Horizontal provenience \\
\hline Level & Excavation level where the feature began \\
\hline Maximum Length & Maximum horizontal length of feature in $\mathrm{cm}$ \\
\hline Maximum Width & Maximum horizontal width of feature in $\mathrm{cm}$ \\
\hline Object ID & Unique identification number in the GIS \\
\hline Other Level & Any levels where feature was present beyond the beginning level \\
\hline Photos & Photo numbers associated with the feature \\
\hline Preservation & State of feature preservation (excellent, good, fair or poor) \\
\hline Shape Area & Feature area, as determined by the GIS \\
\hline Shape Length & Feature circumference, as determined by the GIS \\
\hline Simple Feature Class & Feature class using the most basic categories \\
\hline Square & Unit address \\
\hline Thickness & Vertical depth from the beginning to the end of the feature in $\mathrm{cm}$ \\
\hline Unit & Unit name where the feature was noted \\
\hline \multicolumn{2}{|c|}{$\begin{array}{l}\text { * At Meier, depth was calculated in centimeters below ground surface. At Cathlapotle, depth was } \\
\text { calculated in meters above sea level. }\end{array}$} \\
\hline \multicolumn{2}{|c|}{ Each level form was also examined for structural features. Fairly often, floor } \\
\hline
\end{tabular}


GIS with all relevant attribute data and comments. This information was not included in analysis, but was appended in the GIS in case it had any bearing on broad patterns.

No features from Meier had previously been digitally mapped. At Cathlapotle, features from all but ten excavation units were previously mapped using computer assisted drafting (CAD) (see Sobel 2004). These CAD files were converted to shapefiles compatible with ArcGIS by personnel at Maul, Foster and Alongi, Inc. However, because of CAD software capabilities, only feature class and elevation were included in the CAD files. Therefore, architectural features were redigitized based on Sobel's CAD files and feature forms, enabling additional attribute data to be attached and available for querying related to spatial analysis.

After GIS databases were completed, descriptive statistics were calculated for the entire dataset and for subsets of data. The most common statistically examined measurements were maximum feature length and width. Length refers to the greatest horizontal dimension of the feature and width refers to the measurement perpendicular to length. To test for normal distribution of data, the Shapiro-Wilk test was run for each feature type at each site. Separate tests were run for all features and for only features with complete horizontal measurements.

\section{Plankhouse Construction and Maintenance History}

Seven specific hypotheses were formulated to address house construction and repair history. Hypotheses 1, 2 and 3 query the spatial arrangement of architectural features at the two sites by testing aspects of models proposed by previous researchers. For these hypotheses, a series of GIS maps detail the layout of plank and post features, 
allowing inferences regarding architectural layout to be drawn. These maps group features and display data by a variety of attributes. Hypotheses 4, 5 and 6 are concerned with intrasite spatial patterning of architectural features, while Hypothesis 7 compares the two sites. Hypotheses 4-7 were investigated by a combination of inferences from maps, spatial analysis, and statistical tests. The following discussion details specific methods.

(1) The Cathlapotle House 1 interior was compartmentalized, House 4 and the Meier

House were not. To address this question, GIS maps were generated of postmolds, plankmolds and postholes at each site. These maps enabled features potentially used to compartmentalize the houses to be examined in detail.

(2) Substantial structures were located outside houses. GIS maps of units outside the houses were created to study exterior features on a fine scale.

(3) Placement of structural elements was consistent through time. Maps were created to examine where multiple features are 'stacked' around each other using upper elevations (from site datum). Elevations were divided very finely into 22 groups using equal intervals of $10 \mathrm{~cm}$ at Cathlapotle and $8.3 \mathrm{~cm}$ at Meier, so that small differences between nearby features could be detected. Upper elevations were used for several reasons. First, this measurement was more likely to be documented in field notes than lower elevation. Also, lower elevations may be influenced by feature size (with large features buried deeper). Upper elevation cannot be compared throughout the site as a whole, as this measurement is affected by differences in natural topography and placement in the house. Hence, elevations were compared between neighboring units to reduce these influences. Plankmold elevation was generally assumed to be connected with occupational period, 
that is, plankmolds with higher elevations were assumed to be from later occupations. It should be noted, however, that complex site stratification renders a simple correlation problematic.

(4) Plankhouse orientation was consistent through time. Plank features were split into groups based on their direction (north-south or east-west) or their location in the house (wall or central). Plankmold orientation was determined in the GIS. Changes of house orientation over time were examined using three methods. First, the Spearman's Rank Order Correlation was run between upper elevation and orientation to test for correlation between plank orientation and depth. The Spearman's Rank Order Correlation is a statistic used to test for the presence of positive or negative correlation between two ordinal datasets (Shennan 1997). Second, Linear Directional Mean (LDM) analysis was used to compare orientation of planks of different elevation groups. LDM is a spatial analysis tool that measures the average angle for a group of lines. For this test, plankmolds were split into three groups based on upper elevation using the natural breaks method, and these groups were examined for trends between LDM and depth. Third, maps of plankmolds grouped by elevation were drafted and examined for each house.

(5) Similar structural elements were used in Cathlapotle House 1 and 4, and in Compartments B-D of House 1. Architectural element sizes were compared using the Mann-Whitney test between House 1 and House 4, and also House 1 Compartments B-D. (6) Structural elements differ between facilities. Statistical analysis consisted of comparing sizes of feature classes between facilities using the Mann-Whitney $U$ test and the Kruskal-Wallis H test, which are designed to test for differences in ordinal scale 
variables for one-to-one and more than two categories, respectively (Shennan 1997). One-to-one tests were run for all feature categories in all facilities, but for simplification, only significant results are reported. The chi square test was performed to examine if architectural feature classes were distributed differently between facilities, using both complete and incomplete features. The chi square test is used to compare population proportions between samples (Drennan 2004:183).

(7) Similar structural elements were used at Meier and Cathlapotle. The Mann-Whitney test was performed for length and width of structural features at the two sites, both for the total sample and between facilities. In this analysis, I used only complete features and eliminated post features smaller than $7 \mathrm{~cm}$ in maximum length (to make sites comparable and so that results reflect the features used in architecture rather than household furnishings). As an additional method of comparing architectural feature size between the two sites, the chi square test was performed to assess differences in distribution of size classes at each site for both posts and plank features. Features were divided into size classes using the natural breaks method and were grouped into five classes based on the maximum length measurement. These classes consisted of Class 1: $7 \mathrm{~cm}$ or smaller, Class 2: 7.1-20 cm, Class 3: 20.1-40 cm, Class 4: 40.1-70 cm, Class 5:70.1 cm or larger. Distribution of planks and combined posts (postmolds and postholes) were compared at Meier and Cathlapotle between three facilities. To increase comparability between facilities at the two sites, berm units at Cathlapotle were merged with midden units, and floor units were combined with hearth units.

\section{Plankhouse Construction and Maintenance Costs}


The second main aim of this project was to use architectural feature data to quantify labor required to construct and maintain plankhouses in the LCRR. The first step of this process was to quantify how much raw material was involved in building houses. Material used in plankhouses was calculated by examining both plank sheathing and structural elements such as corner posts (see Figure 7).

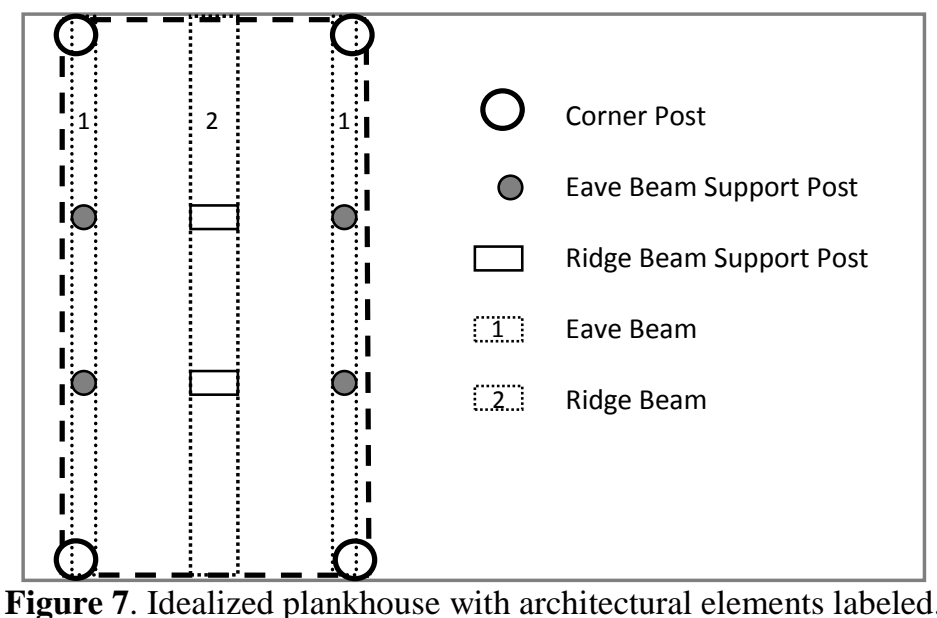

Amount of wood in structural elements was calculated using size and counts for each structural element. Diameter of structural features was estimated using metric data from excavations (Table 3, Appendix A). Since complete, large features were rare, incomplete features were 'completed' when possible ${ }^{1}$. Estimating height of elements and morphological attributes of beams was more difficult, as these elements left no archaeological correlates at Meier and Cathlapotle. Height of structural elements was determined from historical documents and other archaeological sites. Counts of structural elements for each house were also derived from historical sources and other

\footnotetext{
${ }^{1}$ A similar method as described in Gardner-O'Kearney (2010:58) was employed to estimate size of incomplete features. Incomplete circular features were completed based on approximations from the known section. Although completing features is necessary to increase sample size, there are some issues with this technique. It is possible that not all post features were completely circular, some may have been elliptical. Also, it was difficult to complete measurements for plankmolds, resulting in a low sample size for planks.
} 
archaeological data pertaining to spacing of elements. Element quantities used at each house were combined with estimates of element size to extrapolate meters of different diameter logs required for house construction (see Appendix B).

Table 3. Methods of Determining Structural Element Metrics.

\begin{tabular}{lllll}
\hline & Diameter & Reference & Height & Reference \\
\hline Wall plank & $.4 x .1 \mathrm{~m}$ & Excavations, see Tables A-9 and A-10 & $1.5-2.4 \mathrm{~m}$ & Hajda 1994 \\
Corner post & $1 \mathrm{~m}$ & Excavations, see Tables A-9 and A-10 & $1.5-2.4 \mathrm{~m}$ & Hajda 1994 \\
Ridge beam support & $.5 \mathrm{~m}$ & Excavations, see Tables A-9 and A-10 & $4-6.1 \mathrm{~m}$ & Hajda 1994 \\
Eave beam support & $.3 \mathrm{~m}$ & Excavations, see Tables A-9 and A-10 & $1.5-2.4 \mathrm{~m}$ & Hajda 1994 \\
Ridge and eave beam & $.3-1 \mathrm{~m}$ & Mauger 1978, Stewart 1984 & House & Excavations \\
& & & Length & \\
\hline
\end{tabular}

Surface area of siding, roofing and flooring were calculated to determine the area that would need to be covered with planks. Details of all calculations are presented in Appendix B. Roof width was multiplied by roof length to determine the surface area of the roof (Figure 8). Surface area of siding was estimated by adding surface area of the two long axes of the house to the two short axes. Surface area of the long axis was determined by multiplying the length of the houses by the height, using both the small and large range for wall height. Surface area of the short axis was calculated similarly, but took into account the triangular pitch of the roof. At Meier, surface area of the wood floor planking was determined by multiplying the house length by width.

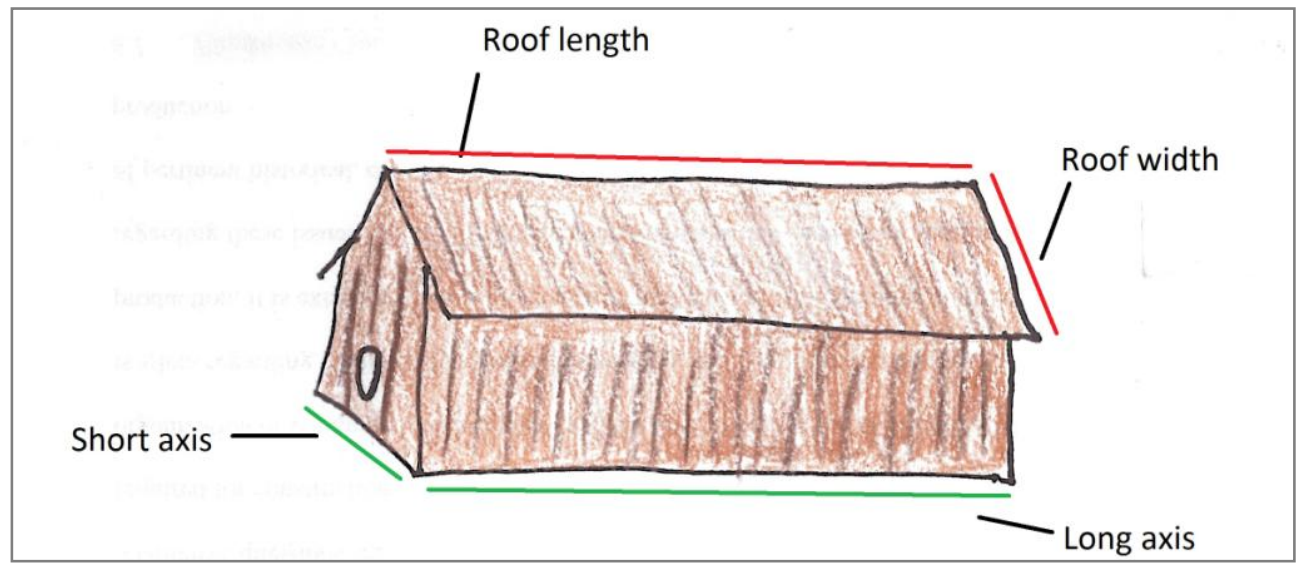

Figure 8. Plankhouse long axis and shirt axis, and roof width and length. 
Surface area calculations were converted into board feet to estimate trees needed for planking used in siding, roofing and flooring (at Meier). Board foot log rules are used to determine how many $12 \times 12 \times 1$ inch board feet can be cut from a round, tapered log. These calculations include several assumptions, including that logs contain no defects, and that some wood is lost to sawdust at the mill. Of course, modern milling equipment was not used by LCRR residents, but wood was finished with adzing, which would result in some wood loss. Board feet were calculated using the Scribner's Log Rule, which states that a $\log$ that is 36 inches in diameter at breast height (approximately one meter) and 20 feet tall has 1150 board feet (Countryman and Kemperman 2000). Since plank width was larger than one inch at the study sites (see Tables 5 and 6) raw board feet calculations were multiplied by a factor of three.

Board feet estimates were combined with meters of logs required for structural elements to produce an approximation of the number of trees required to build houses. For posts and beam elements, a tree measurement of 6.1 usable meters of wood was employed ${ }^{2}$. This number was used because I wanted to maintain compatibility with board feet calculations, which were based on $20 \mathrm{ft}(6.1 \mathrm{~m})$ logs.

The second aspect to quantifying labor was identifying steps involved in building and repairing dwellings. The amount of labor involved various activities was quantified using both experimental archaeology studies and raw material data from Meier and Cathlapotle. Quantifying the time it would take to fell large cedars is complex; because of

\footnotetext{
${ }^{2}$ Employing only $6.1 \mathrm{~m}$ of usable logs may overestimate amount of trees, but other aspects of this thesis underestimate amount of wood used. Examples of this include not accounting for underground portion of structural elements, or the overhanging portion and possible double coursing of roof planks. Therefore, calculations of trees used must be viewed as rough estimates. Another caveat is that for planks, boards were assumed to be split from felled trunks rather than individually pried from standing trees.
} 
differences in technology and tree type, it is difficult to apply ethnoarchaeology or experimental archaeology data to cedar. However, some pertinent points can be drawn from experimental studies. Using stone tools, one group of three experimenters chopped down trees one foot in diameter at a rate of about one per half an hour (Iverson 1956). Similarly, Mathieu and Meyer (1997) show that stone tools can be used to fell trees with 20-30 cm diameter in 30-60 minutes. Specific gravity largely determines the ease of tree felling, with low specific gravity making trees easier to cut. Cedar has a low specific gravity compared with many other trees that grow on the Northwest Coast (see Gahr 2006, Table 2), and also many of the trees used in Matieu and Meyer's study. As data from experimental and ethnoarchaeology related to felling large trees was not available, I used information from small trees to extrapolate to felling times for larger trees. I used as a baseline the figure of .5 hours of work to chop down a tree $30 \mathrm{~cm}$ in diameter, and scaled this up for larger trees ( 2 hours for .5 diameter trees and 4.5 hours for $1 \mathrm{~m}$ diameter trees).

Person days required for excavation of wall trenches and the semi-subterranean portion of the plankhouses were estimated from an experimental archaeology study. Erasmus (1965:285) conducted several experiments, concluding that in one day (five hours) a person using wooden tools could excavate $2.6 \mathrm{~m}^{3}$ of earth.

Weight of wood was calculated in order to better understand effort entailed in moving trees for plankhouses. A baseline weight of 1.41 metric tons $(3,100 \mathrm{lbs})$ per 1000 board feet of green (undried) lumber was used for calculations (Countryman and Kemperman 2000:34). 
Labor involved in maintenance was investigated using data on structural elements, which allowed estimates of how many posts and planks composed structures and enabled more accurate calculations of how much labor was entailed in repair of these elements. Rates of replacement for structural elements were estimated from wood technology studies documenting cedar decay rates, which provide information applicable to assessing how often elements of different sizes would need to be replaced. Although cedar's resistance to decay is well documented compared to other trees found in Northwest Coast forests, it is still subject to rot. Gahr (2006) reports that cedar posts in the area decay at a rate of around $2 \mathrm{~cm}$ per year. Experiments from different regions also demonstrate that although cedar is less prone to decay than other wood, small elements fail rapidly because of rotting. In experiments involving cedar heartwood planks with a largest dimension of $15 \mathrm{~cm}$, these elements took about 11 years to fail in Wisconsin (an average of $1.4 \mathrm{~cm}$ per year), which is an area with a slightly lower decay hazard rating than the LCRR (Highley 1995). In the decay prone area of Hawaii, $96 \%$ of $10 \times 5 \mathrm{~cm}$ cedar heartwood stakes had decayed within four years (Skolmen 1968). In Norway, $60 \%$ of cedar $50 \times 5 \mathrm{~cm}$ boards failed after five years, with the average failing after just 2.6 years (Flate et al. 2009). Replacement rates for untreated cedar shingles used in roofing range from 5-20 years (Buchanan 1992) to 15-60 years (Park 1989). The density decomposition rate per year for western redcedar in Oregon is $0.009 \mathrm{~g} / \mathrm{cm}^{3}$ (Sollins et al. 1987).

Meier and Cathlapotle are located in a moderately high decay hazard location compared with the rest of the United States (see Carll 2009, Figure 2). Decay in cedar is hastened when wood contacts water or soil. Moisture results in loss of wood fiber and an 
increase in splitting (Buchanan 1992) and the anti-decay preservatives in cedar are leachable in water (Loferski 1999). Hence, despite cedar's positive qualities as a building material, structural elements would need to be replaced frequently.

These studies allowed rough estimates of how many times structural elements of varying sizes would need to be replaced during the buildings' uselives (see Chapter 6). I estimate that a plank with base dimensions of $40 \mathrm{~cm}$ in length by $7.6 \mathrm{~cm}$ in width would need to be replaced every 20 years. The large amount of stress from roof weight placed on corner posts, rafter support beams and eave support beams would increase deterioration. However, the larger diameter of these elements would result in slower decomposition than smaller elements. Some clues to how often posts were replaced can be seen in Figures 15-20. Smaller structural posts show signs of being replaced a dozen or more times, while larger elements seem to only have been replaced several times. I assume that smaller posts ( $\sim 30 \mathrm{~cm}$ diameter) would need to be replaced every 15 years. Scaling up based on volume, I estimate that $.5 \mathrm{~m}$ diameter posts would need to be replaced every 50 years and $1 \mathrm{~m}$ posts would need to be replaced approximately every 130 years. Calculations of overall material used allows better understanding of resource and labor costs involved in maintaining plankhouses over their entire uselives. 


\section{Chapter 5: Results of Plankhouse Construction and Maintenance History Analysis}

This chapter presents an overview of the more than 1,100 features that were digitized at Cathlapotle and Meier. Subsequently, results of the seven hypotheses related to plankhouse construction and maintenance history are discussed.

\section{$\underline{\text { Summary of Architectural Features }}$}

The Meier GIS database contains 387 features related to house architecture (Table 4, Figure 9). Of the final 387 features recorded at Meier, 282 have complete horizontal measurements (Table 5). Some features were truncated by other features or by the walls of excavation units. Other features were considered incomplete because of missing provenience information on excavation forms or maps. Although dimensions of features should not be taken as exact measurements of structural elements, they provide valuable information in the absence of the elements themselves. For details of GIS databases for both sites, see Appendix A.

Table 4. Features Included in GIS Databases.

\begin{tabular}{lcccc}
\hline & \multicolumn{2}{c}{ Meier } & \multicolumn{2}{c}{ Cathlapotle } \\
Feature Class & Count & Percent & Count & Percent \\
\hline Plankmold & 129 & $33.3 \%$ & 218 & $28.8 \%$ \\
Posthole & 223 & $57.6 \%$ & 87 & $11.5 \%$ \\
Postmold & 23 & $5.9 \%$ & 296 & $39.1 \%$ \\
Rock & 4 & $1.0 \%$ & 0 & $0 \%$ \\
Step & 1 & $0.3 \%$ & 0 & $0 \%$ \\
Wall trench & 7 & $1.8 \%$ & 29 & $3.8 \%$ \\
Pegmold & 0 & $0 \%$ & 109 & $14.4 \%$ \\
Peghole & 0 & $0 \%$ & 14 & $1.8 \%$ \\
Puddle & 0 & $0 \%$ & 2 & $0.3 \%$ \\
Woodstake & 0 & $0 \%$ & 1 & $0.1 \%$ \\
Log & 0 & $0 \%$ & 1 & $0.1 \%$ \\
Total & 387 & $100 \%$ & 757 & $100 \%$ \\
\hline
\end{tabular}

Four feature classes recorded at Meier are of primary significance to this project: plankmolds, postholes, postmolds and wall trenches. Comparative analysis of post 
features between Meier and Cathlapotle was enabled by further parsing post features by size. Small circular features were field classified as pegs at Cathlapotle, but this category was not used at Meier. Hence, for much subsequent analysis, small post features at Meier (largest dimension equal or less than $7 \mathrm{~cm}$ ) were reclassified as pegs. These posts were likely used for purposes unrelated to architecture, such as drying racks (see Mauger 1978:118). After filtering out peg features, 104 postholes and 15 postmolds remain in the Meier database. In statistical analyses, postmolds were sometimes grouped with postholes to increase sample size. Plankmolds, postholes, postmolds and combined posts with complete measurements did not have normal distributions in respect to length, width or depth (Appendix A).

Table 5. Descriptive Statistics for Meier Features with Complete Horizontal Measurements.

\begin{tabular}{ccccccc}
\hline \multicolumn{2}{c}{ Feature } & Count & Min. $(\mathrm{cm})$ & Max. $(\mathrm{cm})$ & Mean $(\mathrm{cm})$ & Std. Deviation $(\mathrm{cm})$ \\
\hline \multirow{3}{*}{ Plankmold } & Length & 74 & 6.0 & 105.0 & 22.3 & 19.1 \\
& Width & 74 & 2.0 & 40.0 & 7.8 & 6.8 \\
\multirow{3}{*}{ Posthole } & Length & 189 & 2.0 & 80.0 & 10.0 & 11.2 \\
& Width & 189 & 1.0 & 65.0 & 8.2 & 9.1 \\
& Length & 19 & 4.0 & 36.0 & 13.4 & 10.2 \\
& Width & 19 & 3.0 & 36.0 & 11.0 & 9.9 \\
\hline
\end{tabular}

The Cathlapotle GIS database includes 757 features related to house architecture (Table 4, Figures 10 and 11). Of the features recorded at Cathlapotle, 451 have complete horizontal measurements. As at Meier, some features were incomplete because of either 
intersection with unit walls or other features (see

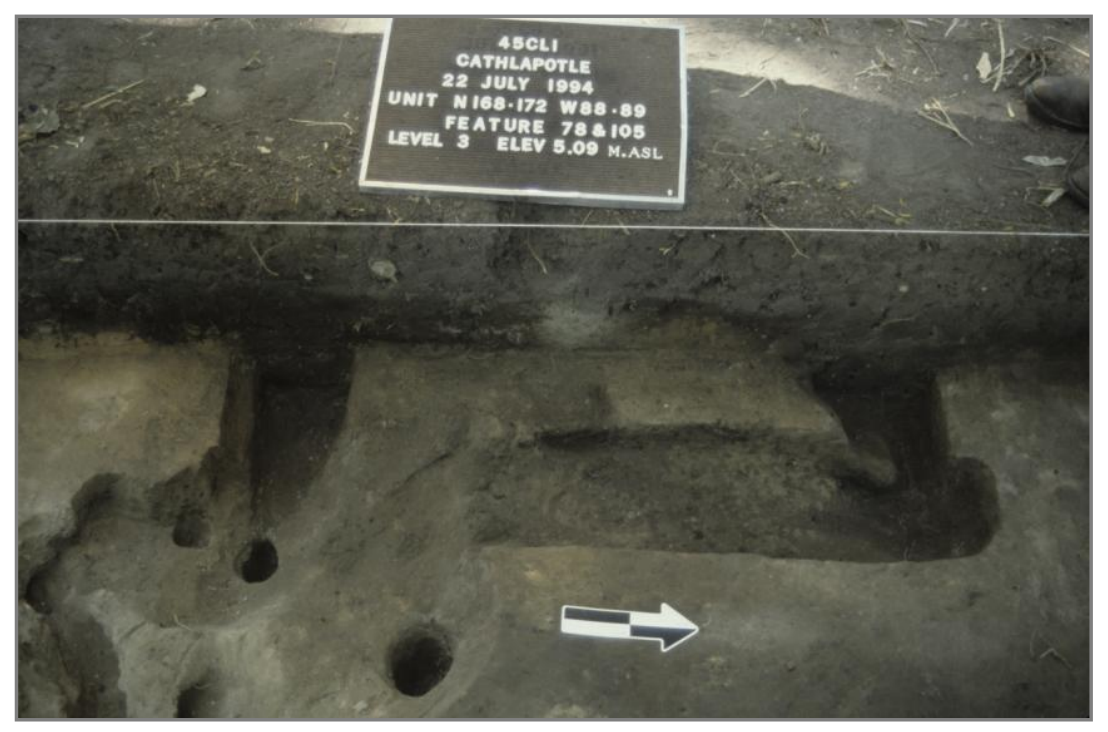

Figure 12). Table 6 presents descriptive statistics for features with complete horizontal measurements, no wall trenches had complete horizontal measurements. Four of the feature classes at Cathlapotle were significant for this project: wall trenches, plankmolds, postholes and postmolds. Length, width and depth of these classes were not normally distributed (Appendix A). 


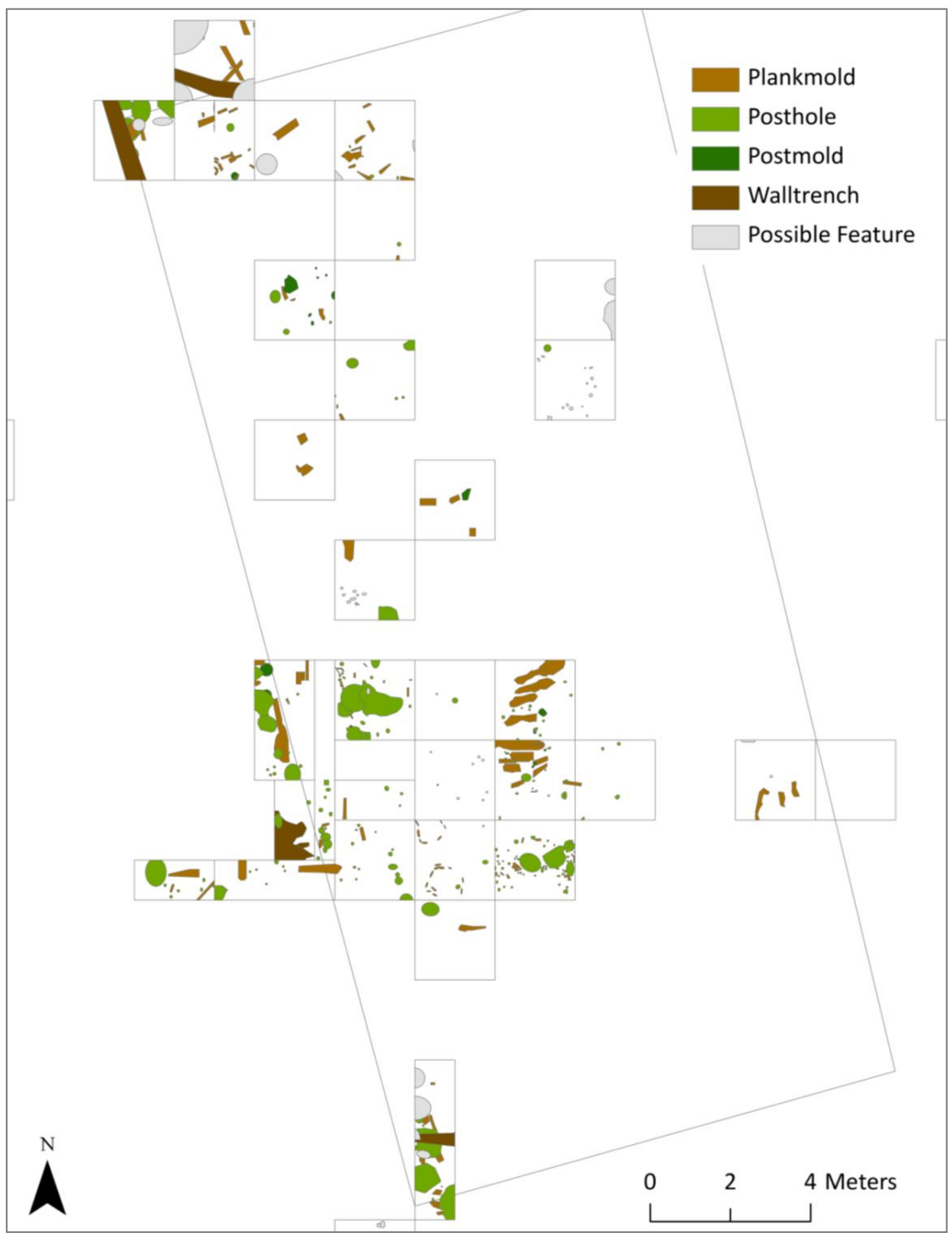

Figure 9. Architectural features recorded at Meier, including possible features. 


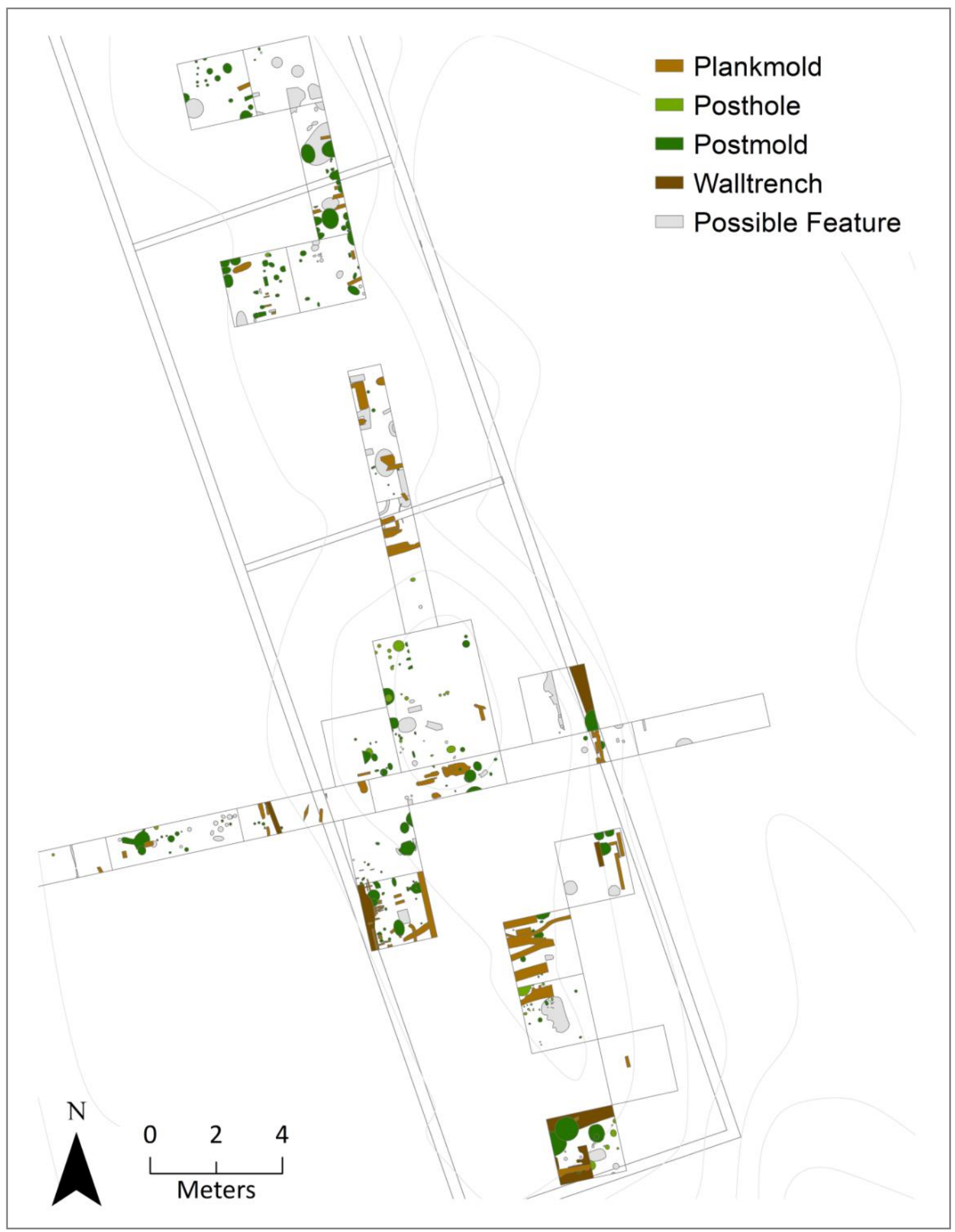

Figure 10. Architectural features recorded at Cathlapotle House 1, including possible features. 


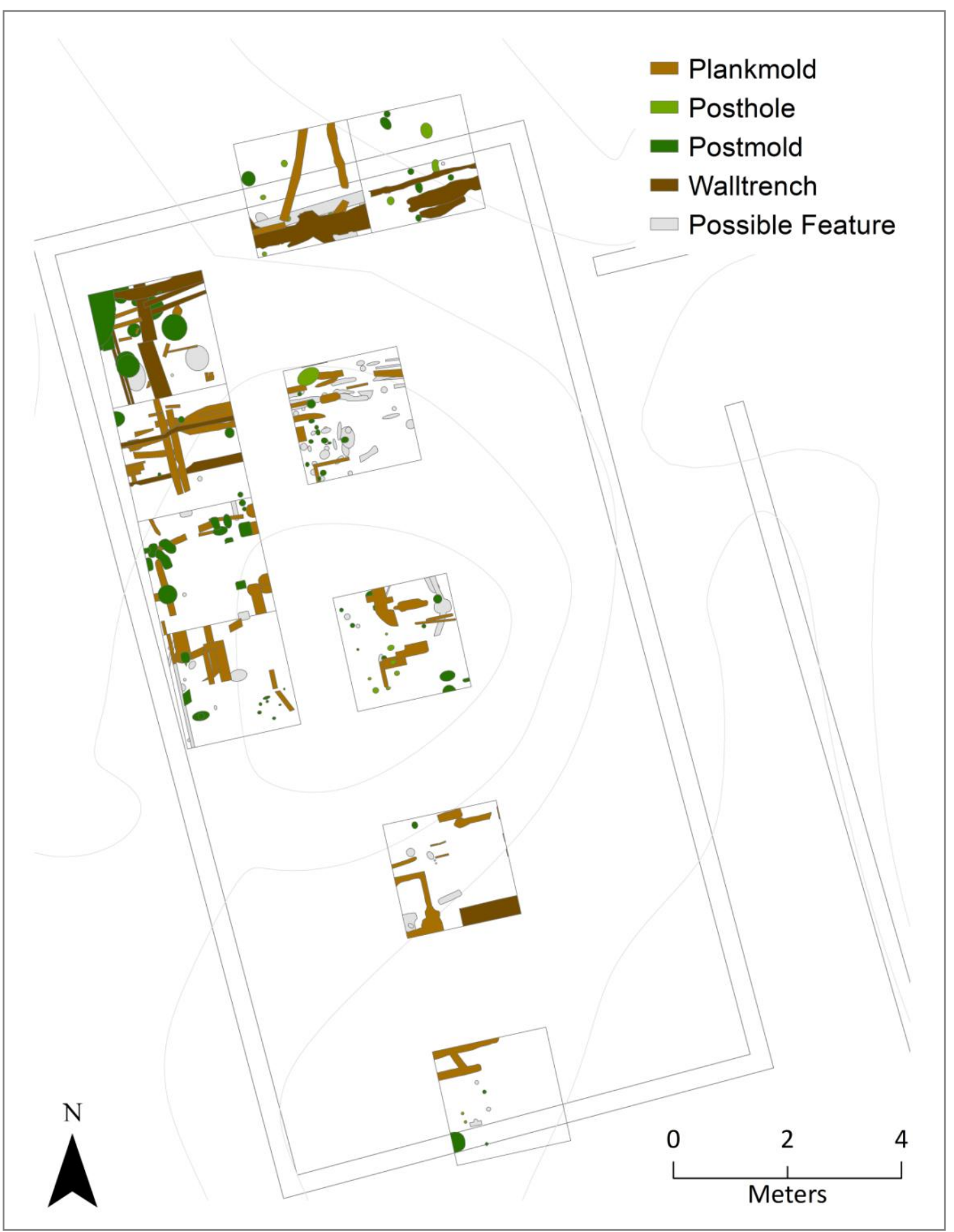

Figure 11. Architectural features recorded at Cathlapotle House 4, including possible features. 


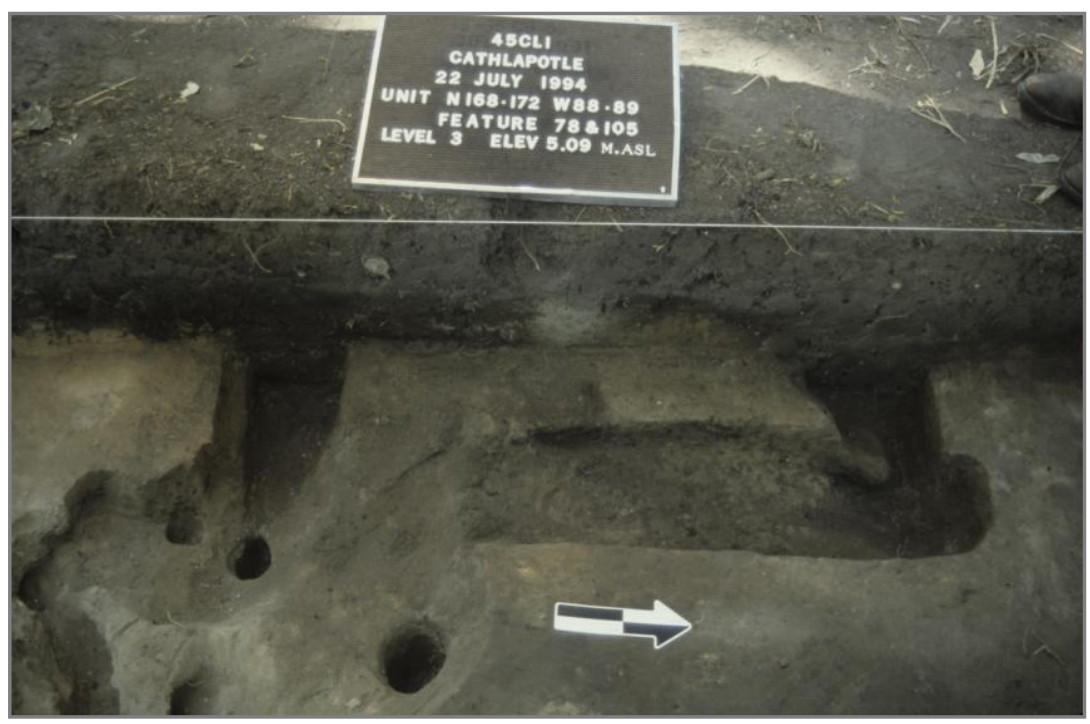

Figure 12. Example of incomplete features at Cathlapotle, truncated by both unit walls and other features.

Table 6. Descriptive Statistics for Cathlapotle Features with Complete Horizontal Measurements.

\begin{tabular}{|c|c|c|c|c|c|c|}
\hline & & Count & $\begin{array}{l}\text { Minimum } \\
(\mathrm{cm})\end{array}$ & $\begin{array}{l}\text { Maximum } \\
(\mathrm{cm})\end{array}$ & $\begin{array}{c}\text { Mean } \\
(\mathrm{cm})\end{array}$ & $\begin{array}{c}\text { Std. Deviation } \\
(\mathrm{cm})\end{array}$ \\
\hline \multirow[t]{2}{*}{ Plankmold } & Length & 64 & 7.0 & 81.0 & 32.7 & 19.2 \\
\hline & Width & 64 & 2.0 & 70.0 & 9.89 & 9.7 \\
\hline \multirow[t]{2}{*}{ Posthole } & Length & 71 & 2.0 & 42.0 & 10.1 & 7.4 \\
\hline & Width & 71 & 2.0 & 34.0 & 9.1 & 6.4 \\
\hline \multirow[t]{2}{*}{ Postmold } & Length & 206 & 3.0 & 73.0 & 13.8 & 11.1 \\
\hline & Width & 206 & 3.0 & 123.0 & 12.0 & 11.9 \\
\hline \multirow[t]{2}{*}{ Pegmold } & Length & 98 & 2.0 & 17.0 & 6.9 & 3.3 \\
\hline & Width & 98 & 2.0 & 13.0 & 5.7 & 2.4 \\
\hline \multirow[t]{2}{*}{ Peghole } & Length & 12 & 4.0 & 12.0 & 7.7 & 3.2 \\
\hline & Width & 12 & 2.0 & 12.0 & 7.2 & 3.2 \\
\hline
\end{tabular}

\section{Plankhouse Construction and Maintenance History}

This section presents results of the seven hypotheses associated with household construction and maintenance.

\section{(1) The Cathlapotle House 1 interior was compartmentalized, House 4 and the Meier}

\section{House were not.}

Patterns of distribution in feature class and size were used to reconstruct the layout of interior architectural elements to assess evidence for compartmentalization at each house. GIS maps support that Cathlapotle House 1 was compartmented, provide 
ambiguous evidence regarding House 4, and indicate that the Meier House was not divided. Strong evidence for compartmentalization of House 1 comes from the low ridges dividing the house that run perpendicular to house walls. Ridges between the D and C compartments and the $\mathrm{C}$ and $\mathrm{B}$ compartments are flanked by some large and many medium-sized planks and posts (Figure 13). Features present in ridges likely represent elements of planks used to divide the compartments. Maps of feature classes at the Meier House and Cathlapotle House 4 show that similar clusters of features and ridges are not as obviously present at these houses (see Figures 9 and 11). However, House 4 contains a row of plankmolds running parallel to the north wall in the northernmost center unit. These features likely represent a reset wall, but they may be remnants of a partition that once segmented the house.

(2) Substantial structures were located outside houses.

At Cathlapotle, 74 of 757 total features are located outside of house walls in 16 units classified as either midden or berm. Exterior units comprise $36 \%$ of the total excavated volume at Cathlapotle. However, only $10 \%$ of total architectural features at Cathlapotle were noted in exterior units. These figures reflect a small proportion of architectural features to be located outside the houses. Of the possible features classified during this project, $26 \%$ are located in exterior areas. Generally, these features were located in units where confirmed features had been recorded. Although not much information can be drawn from possible features, they could indicate more structural elements were present than previously noted. 


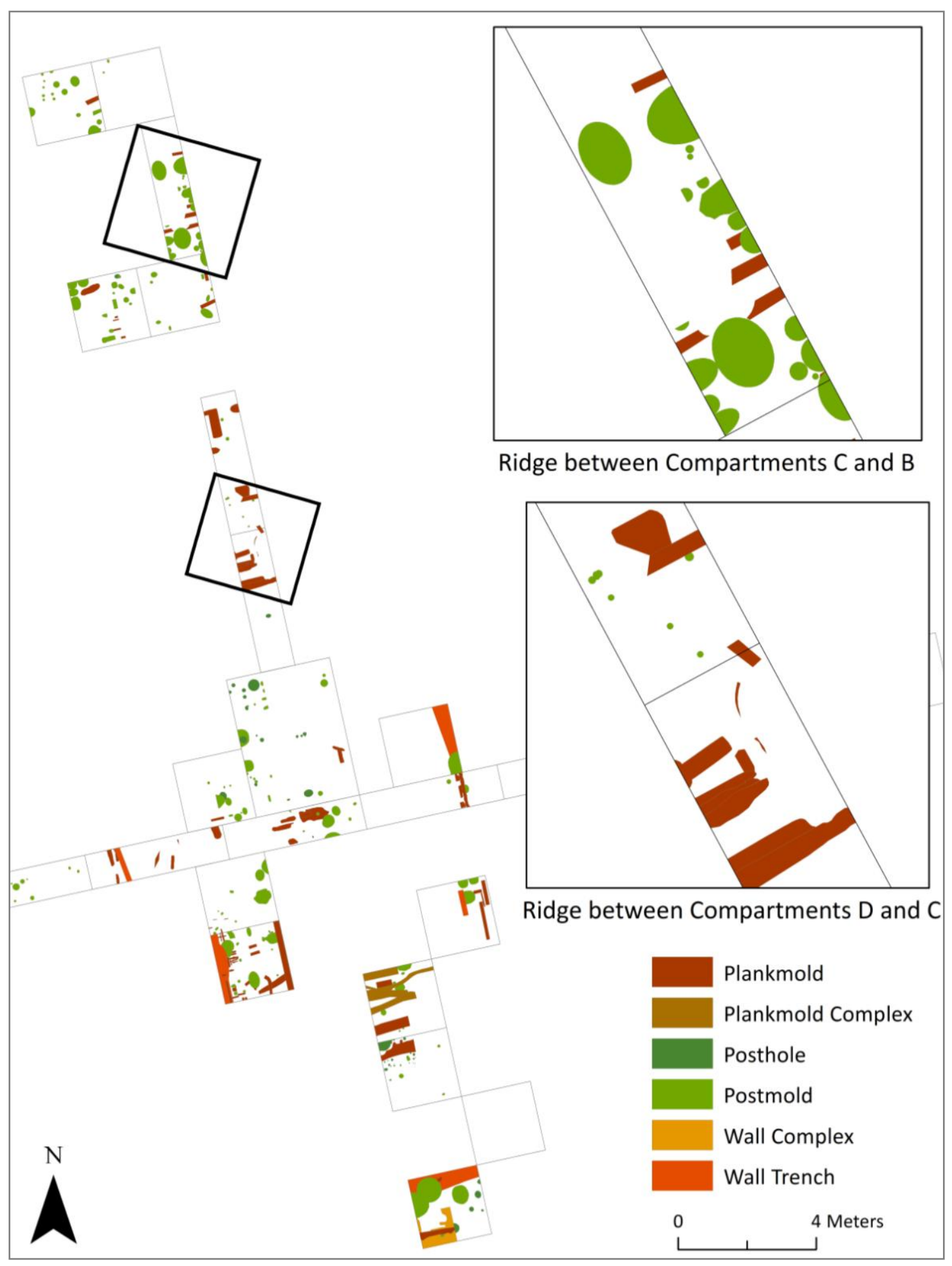

Figure 13. Architectural features flanking compartments, Cathlapotle House 1. 
Several exterior units were selected for additional study based on the large number of features they contained (Figure 14, Table 7). Some of these exterior clusters can be associated with other features based on contextual information. Three clusters of features were found in close proximity to known ovens (in Units D, I and T2). Ten exterior earth ovens were located at Cathlapotle (Gardner-O'Kearny 2010). Outdoor ovens in the LCRR were likely used for preparation of fish, roots, bulbs and nuts (Thoms 1998). Plank and post features located by ovens may indicate the presence of racks or other simple structures. Other clusters of exterior features appear to be associated with house walls or small exterior structures.

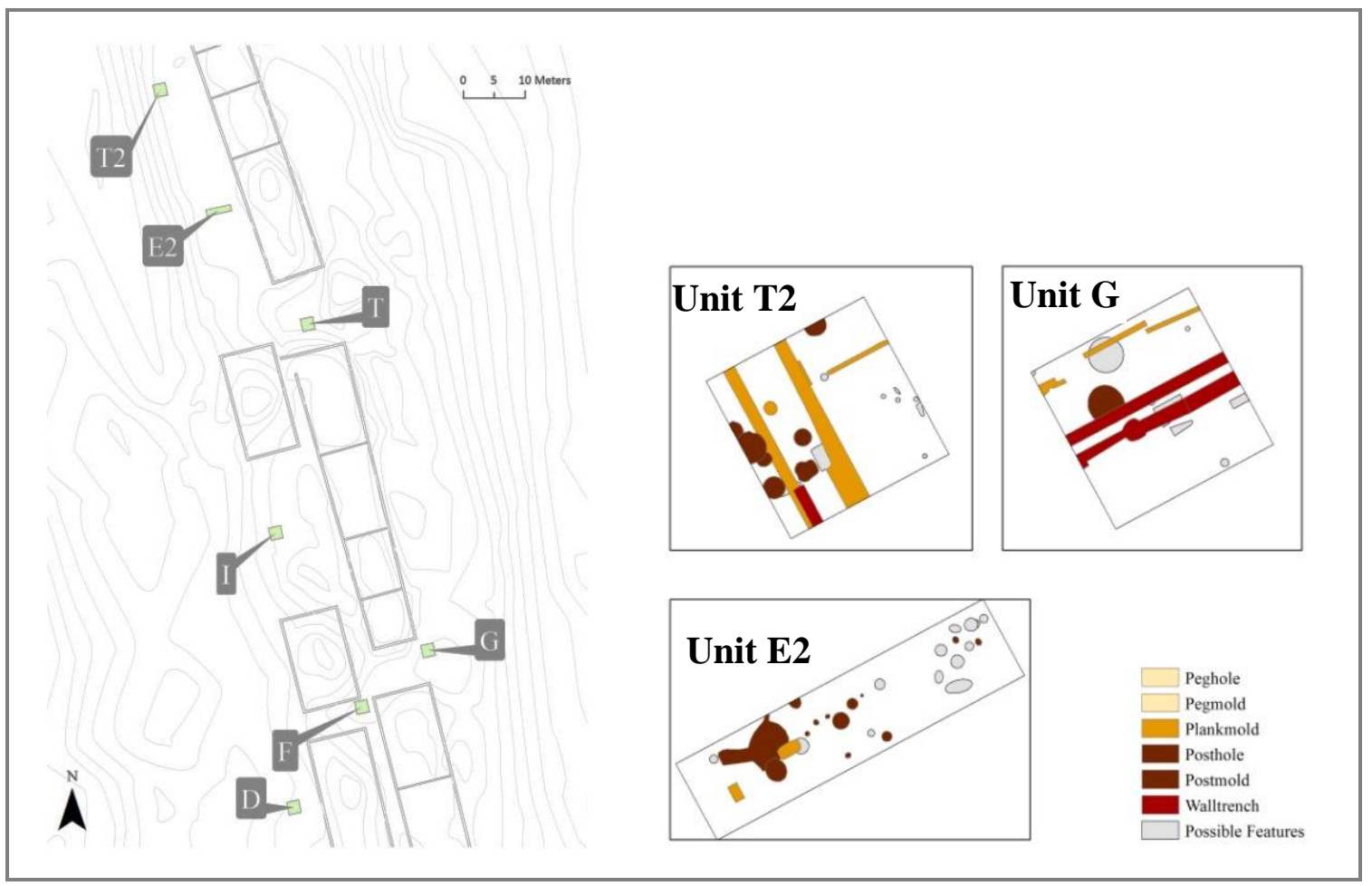

Figure 14. Exterior features at Cathlapotle, (left) location of exterior units with major groups of features, (right) selected clusters of exterior features.

Some exterior features at Cathlapotle are not associated with house walls or known earth ovens. The eastern edge of Unit G2 contains three post features with similar 
elevations arranged in a half circle. These scattered posts likely indicate the presence of various small, impermanent structures. Other units, notably Units T, F and D contain scattered small posts and plankmolds.

Table 7. Selected Groups of Exterior Features at Cathlapotle.

\begin{tabular}{|c|c|c|}
\hline Unit & Feature Description & $\begin{array}{l}\text { Feature } \\
\text { Count }\end{array}$ \\
\hline $\mathrm{D}$ & $\begin{array}{l}\text { Two clusters of features are located in Unit D. In the northwest section of this unit, } \\
\text { four small postholes were discovered that are likely associated with a nearby oven. } \\
\text { The southeast section contains one plankmold and three small postholes. }\end{array}$ & 8 \\
\hline E2 & $\begin{array}{l}\text { This } 4 \times 1 \text { unit contains } 13 \text { post features and two plankmolds. Most of the features are } \\
\text { clustered in the western half of this unit, further away from the house. These features } \\
\text { are associated with Feature } 60 \text {, an outdoor hearth. }\end{array}$ & 15 \\
\hline I & $\begin{array}{l}\text { A small concentration of features was found, consisting of two plankmolds and one } \\
\text { post feature. These features were likely associated with an ephemeral outdoor } \\
\text { structure. }\end{array}$ & 3 \\
\hline G & $\begin{array}{l}\text { This cluster of features consists of wall trenches running approximately east-west, } \\
\text { three plankmolds north and parallel to the wall trenches, and one post feature. These } \\
\text { features suggest a house wall once extended to this area and was then buried in later } \\
\text { occupation. }\end{array}$ & 7 \\
\hline $\mathrm{T} 2$ & $\begin{array}{l}\text { Features were found in association with what was noted in the field as a possible } \\
\text { outdoor structure with a nut oven. These features include a large (over one meter) } \\
\text { plankmold and a wall trench running parallel, three smaller plankmolds and eight post } \\
\text { features. The large concentration and variety of architectural elements in this unit } \\
\text { suggest a substantial feature. Beginning elevation for features in this unit starts at } 5.4 \\
\text { masl, and continue for } 50 \mathrm{~cm} \text { lower, exhibiting variety in upper elevations. However, } \\
\text { the three largest features (the two largest plankmolds and the wall trench) and six of } \\
\text { the post features begin at the same level, suggesting they are the remnants of a single } \\
\text { structure. }\end{array}$ & 13 \\
\hline
\end{tabular}

Several midden units at Cathlapotle contain no architectural features. Of the five exterior units with no architectural features, four are located east of House 1. The lack of features in these units indicates that the east sides of the houses, away from the river, were not heavily utilized for production activities. However, the excavated volume of three units to the east of the house is less than $5 \%$ of the site total, meaning the lack of features could result from sampling.

Exterior structures at Meier exhibit a completely different pattern than at Cathlapotle. At Meier, 12 of 45 units (27\%) were located in units defined as exterior or midden. However, architectural features were almost completely lacking outside the 
Meier House. Out of the total architectural features located at Meier, only 5\% are found in exterior areas. A total of 21 architectural features were found in exterior areas, consisting of six plankmolds and fifteen postholes. Architectural features were located only in three exterior units. Unit $\mathrm{J} 2$ is adjacent to the house wall and contains seven architectural features - two plankmolds and five postholes. Unit K2, which is just east of Unit $\mathbf{J} 2$ contains three plankmolds and seven postholes, one of which is a large Class 4 posthole. The close proximity of these units to the house indicates that these features are associated either with the western house wall or with an exterior structure immediately adjacent to the house. Unit $\mathrm{O} 2$ is located about 14 meters south of the southern house wall, and contains three small postholes and one small plankmold. The dearth of exterior architectural features extended to possible features, as only 3 of $152(2 \%)$ possible features were noted in exterior areas.

There is a striking contrast between exterior architectural features at Meier and Cathlapotle. At Cathlapotle, although architectural features are clearly less plentiful in exterior areas that in house interiors, these features indicate that some building activity occurred in outside areas. A few exterior structures entailed significant materials and labor, as evidenced by wall trenches and large plankmolds. Most structures, however, were likely temporary and insubstantial. At Meier, if exterior features located in Units J2 and $\mathrm{K} 2$ are indeed associated with the house wall, the only evidence of outdoor structures are the few features noted in Unit O2. Clearly, there is more variation in exterior features at Cathlapotle. This aligns with the lack of exterior ovens at Meier, while some were 
found at Cathlapotle (Gardner-O'Kearney 2010). In contrast, interior pit storage features were more varied in form at Meier than Cathlapotle (Butler 2007:67).

\section{(3) Placement of structural elements was consistent through time.}

To examine replacement of planks and posts, I created maps detailing upper elevations of features. These maps were used to compare both spatial redundancy and elevations of neighboring features. Spatial redundancy refers to overlapping features of the same class, which indicates element replacement. As discussed in the methods section, comparisons of elevation must be treated with caution. Elevation is influenced by location within the house - i.e. whether it is on the depression edge or interior. Therefore, effort was taken to primarily compare features from the same facility or house section.

At Meier, several areas in the west wall displayed redundant features with differing upper elevations (Table 8, Figure 15). This suggests features were placed in the same area over time, but that their elevations may have changed slightly. This may have been a result of refuse accumulation in tofts. In the central house area, elements were replaced in very similar vertical and horizontal positions over time (Table 8, Figure 16).

Table 8. Vertical and Horizontal Positioning of Architectural Features, Meier.

\begin{tabular}{|c|c|c|c|}
\hline $\begin{array}{l}\text { General } \\
\text { Area }\end{array}$ & $\begin{array}{l}\text { Specific } \\
\text { Area }\end{array}$ & Units & Observations \\
\hline \multirow[t]{3}{*}{$\begin{array}{l}\text { Walls } \\
\text { (Figure 15) }\end{array}$} & $\begin{array}{l}\text { Northwest } \\
\text { corner }\end{array}$ & $\begin{array}{l}\text { A, B, } \\
\text { C }\end{array}$ & $\begin{array}{l}\text { Several wall trenches are in close proximity to post features that } \\
\text { began on a slightly higher elevation (Units A \& B), and to several } \\
\text { plank features that began on a lower elevation (Units A \& C). }\end{array}$ \\
\hline & $\begin{array}{l}\text { Central } \\
\text { west }\end{array}$ & $\begin{array}{l}\text { E2, } \\
\text { F2A, } \\
\text { F2B, } \\
\text { G2, } \\
\text { K2, P, } \\
\text { Q, W }\end{array}$ & $\begin{array}{l}\text { Much more variation in beginning elevation than the northwest } \\
\text { corner. There are two instances where architectural features in close } \\
\text { horizontal location begin at different elevations. (1) In the western } \\
\text { edge of the wall, three similarly sized posts began at different } \\
\text { elevations (Unit P). (2) East of the wall, there are examples of } \\
\text { similarly sized posts layered directly on top of another (Unit Q). }\end{array}$ \\
\hline & $\begin{array}{l}\text { Southwest } \\
\text { corner }\end{array}$ & M2 & Three large post features have very similar upper elevations. \\
\hline $\begin{array}{l}\text { Central } \\
\text { area } \\
\text { (Figure 16) }\end{array}$ & All & $\begin{array}{l}\text { S, Y, } \\
\text { I2 }\end{array}$ & $\begin{array}{l}\text { Most features are largely at the similar elevations - many features in } \\
\text { the same class have similar horizontal and vertical locations. Some } \\
\text { small features are lower in elevation (most are associated with pits). }\end{array}$ \\
\hline
\end{tabular}


At Cathlapotle House 1, most features were in similar horizontal positions,

although upper elevation of feature in walls seems to have varied more strongly than at Meier (Table 9, Figure 17). Evidence from postholes and wall trenches in the southern wall suggests possible positioning changes in this part of the house. At Cathlapotle House 1, central areas have high densities of similar architectural features, suggesting that elements were replaced many times although keeping approximately the same elevations during the house's uselife (Table 9, Figure 18). Most evidence for larger planks and frequent replacement of these planks was found in Compartment D, the high status area.

Table 9. Vertical and Horizontal Positioning of Architectural Features, Cathlapotle House 1.

\begin{tabular}{|c|c|c|c|}
\hline $\begin{array}{l}\text { General } \\
\text { Area }\end{array}$ & $\begin{array}{l}\text { Specific } \\
\text { Area }\end{array}$ & Units & Observations \\
\hline \multirow[t]{3}{*}{$\begin{array}{l}\text { Walls } \\
\text { (Figure 17) }\end{array}$} & East wall & $\begin{array}{l}\mathrm{B} 2, \\
\mathrm{~N} 2, \mathrm{Y}\end{array}$ & $\begin{array}{l}\text { Upper elevations of northern features appear slightly deeper than } \\
\text { those of the southern line of features. }\end{array}$ \\
\hline & West wall & $\mathrm{I} 2$ & $\begin{array}{l}\text { Features vary in upper elevation. This area contains a wall trench } \\
\text { and large plankmold with high upper elevations. These features } \\
\text { are layered over additional large plankmolds. Several large } \\
\text { postholes with even deeper upper elevations are present. }\end{array}$ \\
\hline & South wall & $\mathrm{U}$ & $\begin{array}{l}\text { This area contains several large postmolds with different } \\
\text { beginning elevations, and two wall trenches with beginning } \\
\text { elevations } 30 \mathrm{~cm} \text { apart. Evidence from postholes and wall } \\
\text { trenches in the southern wall suggests possible positioning } \\
\text { changes in this part of the house. }\end{array}$ \\
\hline \multirow{4}{*}{$\begin{array}{l}\text { Central } \\
\text { area } \\
\text { (Figure 18) }\end{array}$} & $\begin{array}{l}\text { North } \\
\text { central area }\end{array}$ & $\mathrm{S} 2$ & $\begin{array}{l}\text { Most features are very similar in upper elevation, although a } \\
\text { cluster of features in the northern area of the unit are deeper. }\end{array}$ \\
\hline & $\begin{array}{l}\text { Middle of } \\
\text { central area }\end{array}$ & $\mathrm{O} 2, \mathrm{P} 2$ & Features are extremely similar in upper elevation. \\
\hline & $\begin{array}{l}\text { Middle of } \\
\text { central area }\end{array}$ & $\mathrm{C} 2$ & $\begin{array}{l}\text { Some variation in upper elevation, with a cluster of deeper } \\
\text { features interspersed with several posts with higher elevations. }\end{array}$ \\
\hline & $\begin{array}{l}\text { South of } \\
\text { central area }\end{array}$ & $\mathrm{W}, \mathrm{X}$ & $\begin{array}{l}\text { Many central ridge beam supports were used in approximately } \\
\text { the same elevation. In one area, at least six large plankmolds } \\
\text { were noted. }\end{array}$ \\
\hline
\end{tabular}

At Cathlapotle House 4, feature elevation in walls suggests multiple episodes of element replacement in similar areas (Table 10, Figure 19). Variation in elevation occurs in the north and west house walls. Architectural features in the central house area also exhibited moderate variation in upper elevation. Since House 4 contains several 


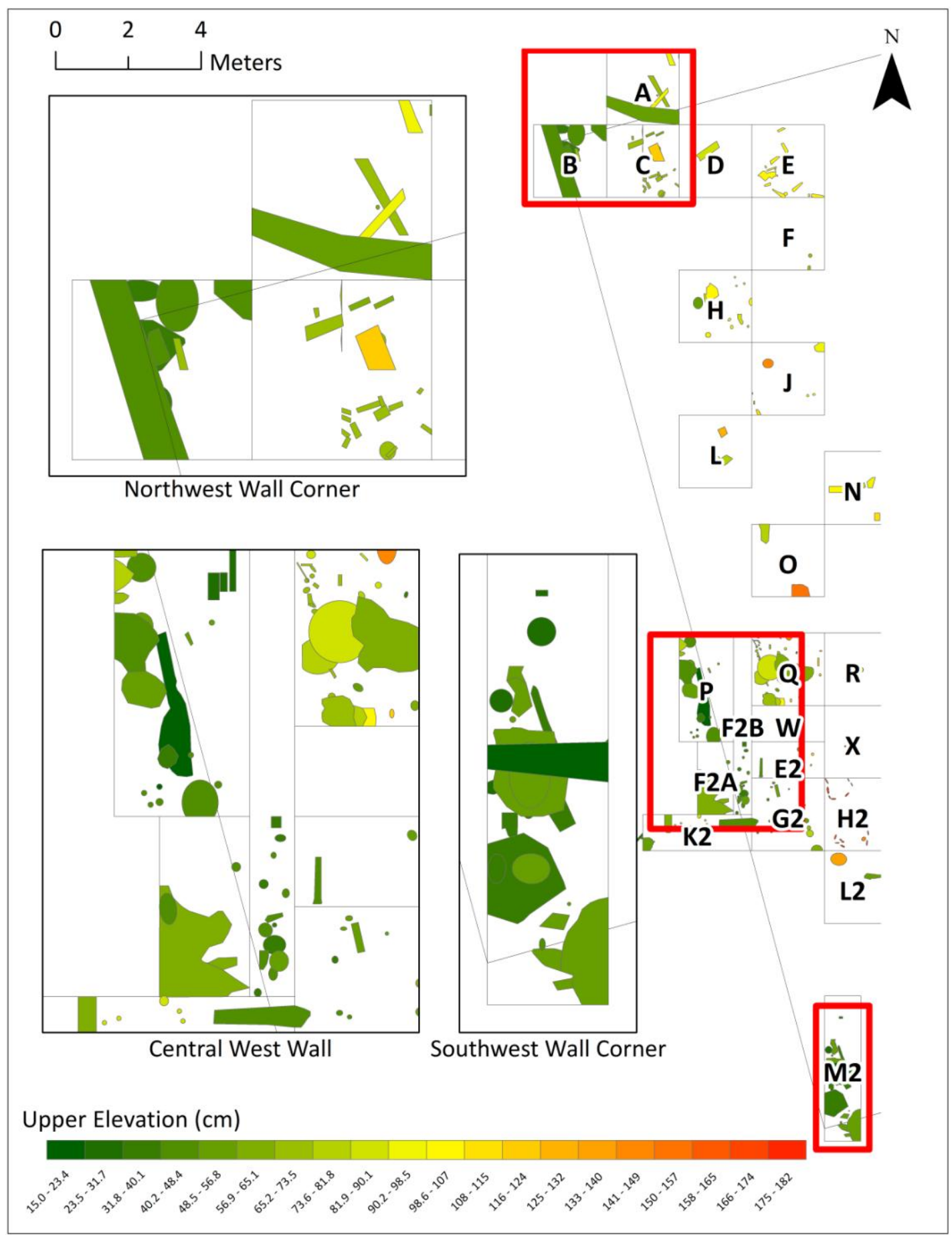

Figure 15. Upper elevation of architectural features in the west wall, Meier House. 


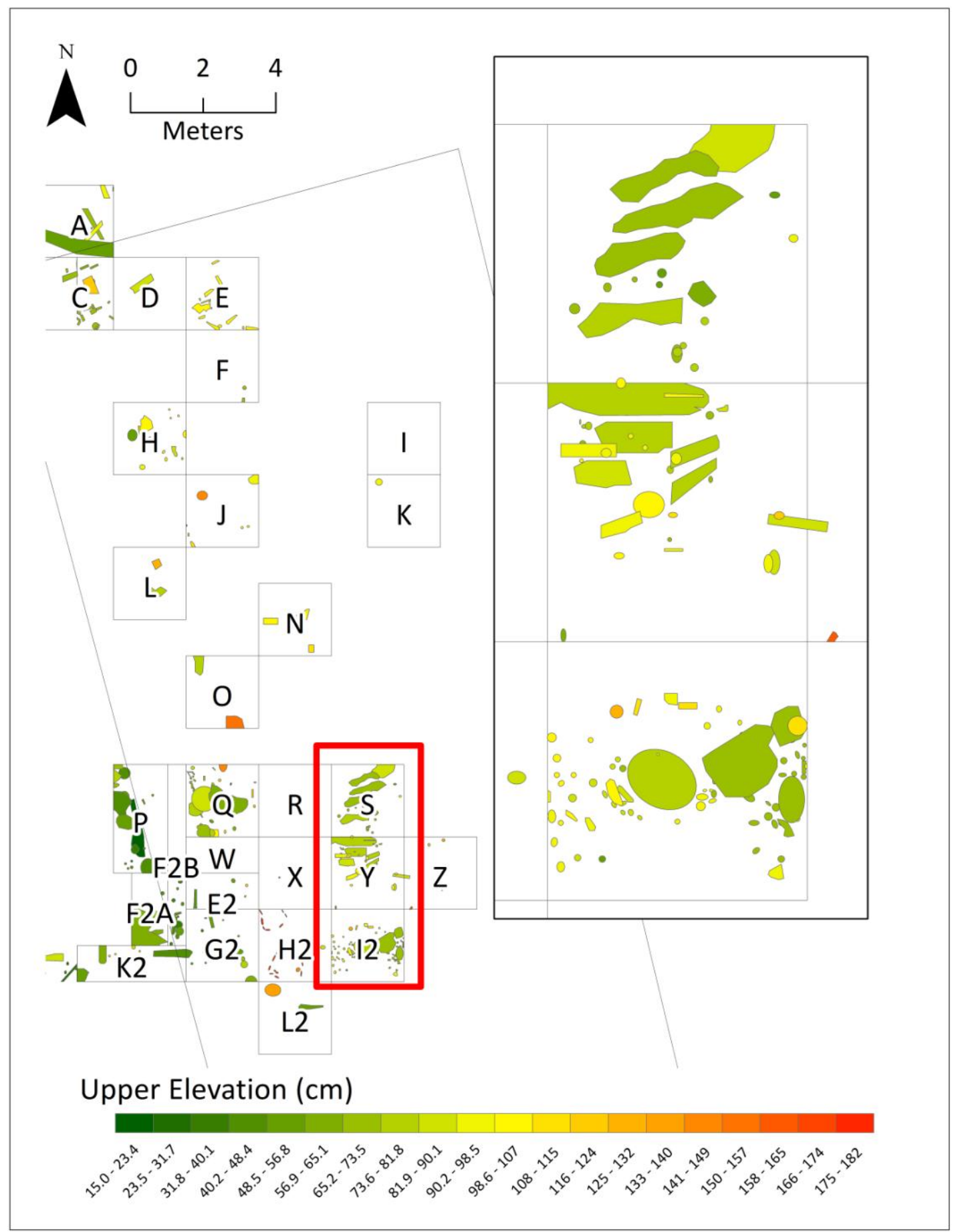

Figure 16. Upper elevation of architectural features in central areas, Meier House. 


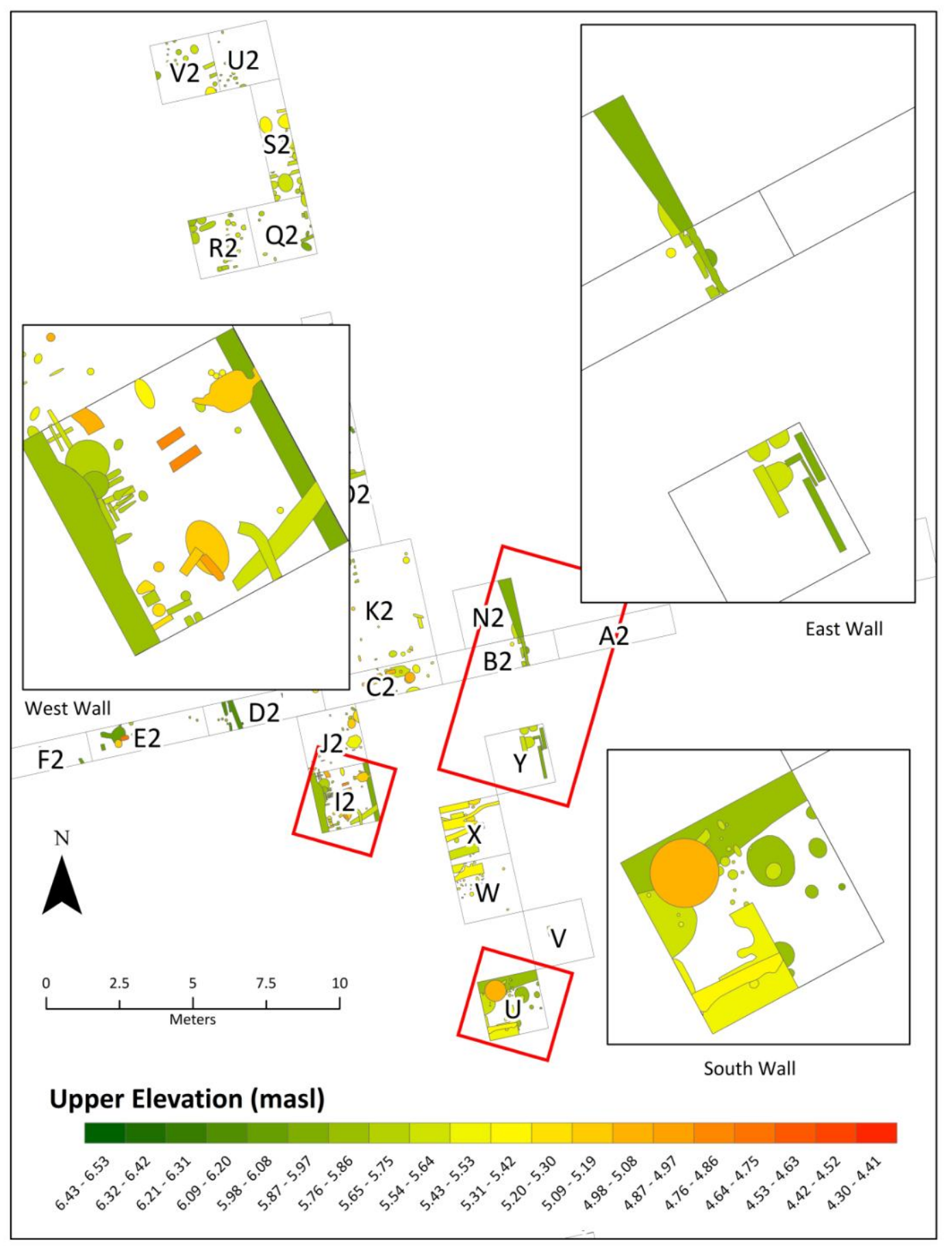

Figure 17. Upper elevation of architectural features in walls, Cathlapotle House 1. 


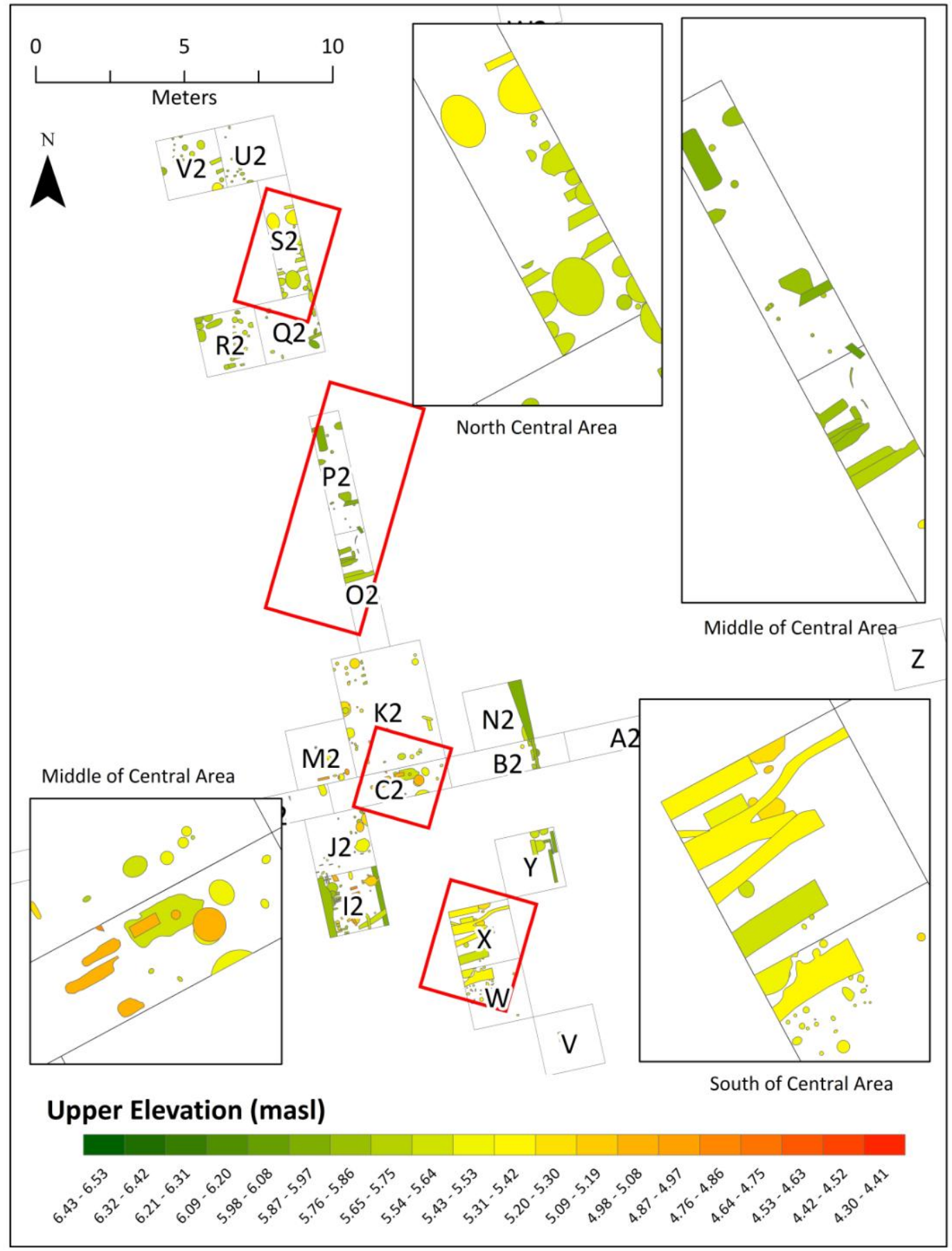

Figure 18. Upper elevation of architectural features in central areas, Cathlapotle House 1. 


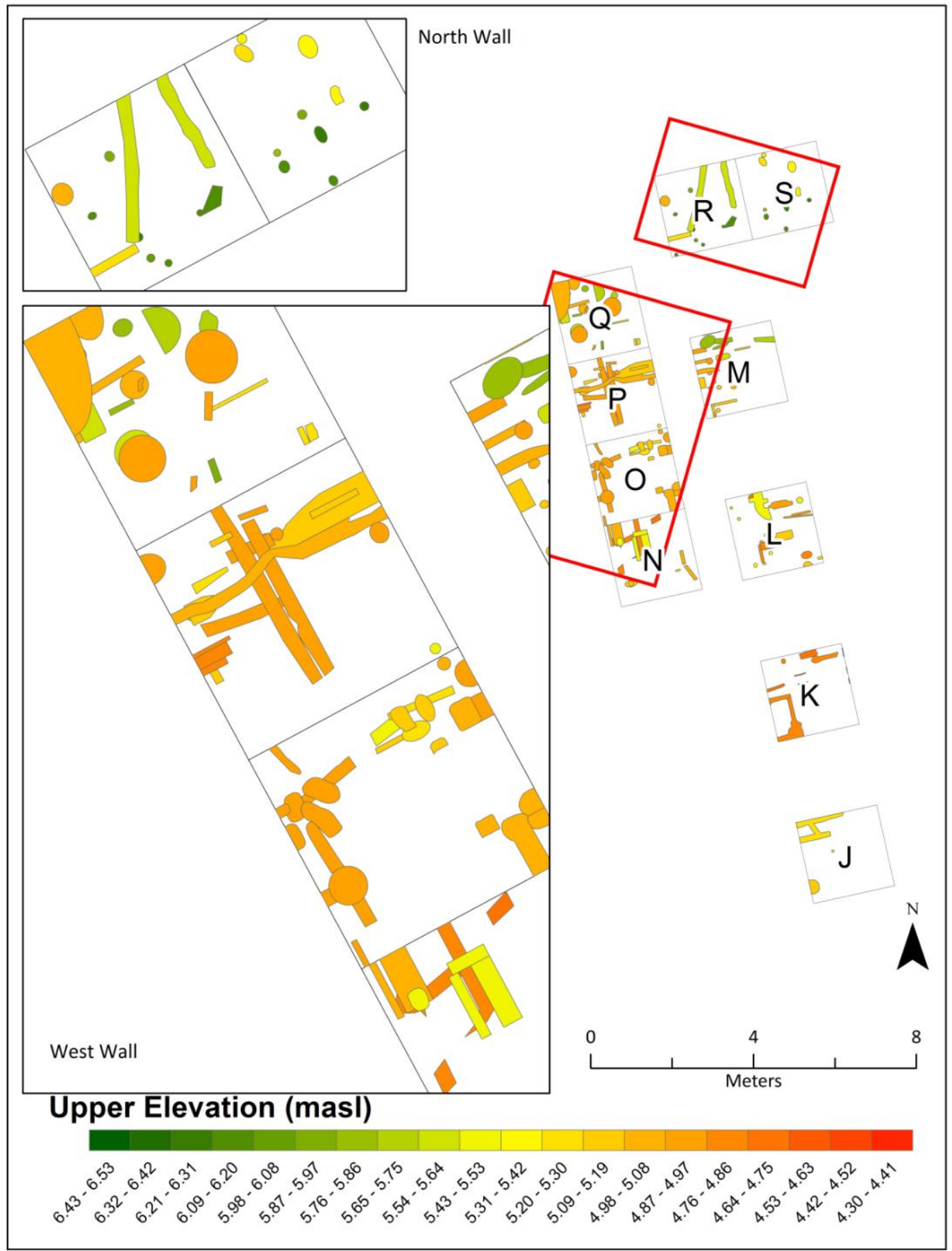

Figure 19. Upper elevation of architectural features in walls, Cathlapotle House 4. 


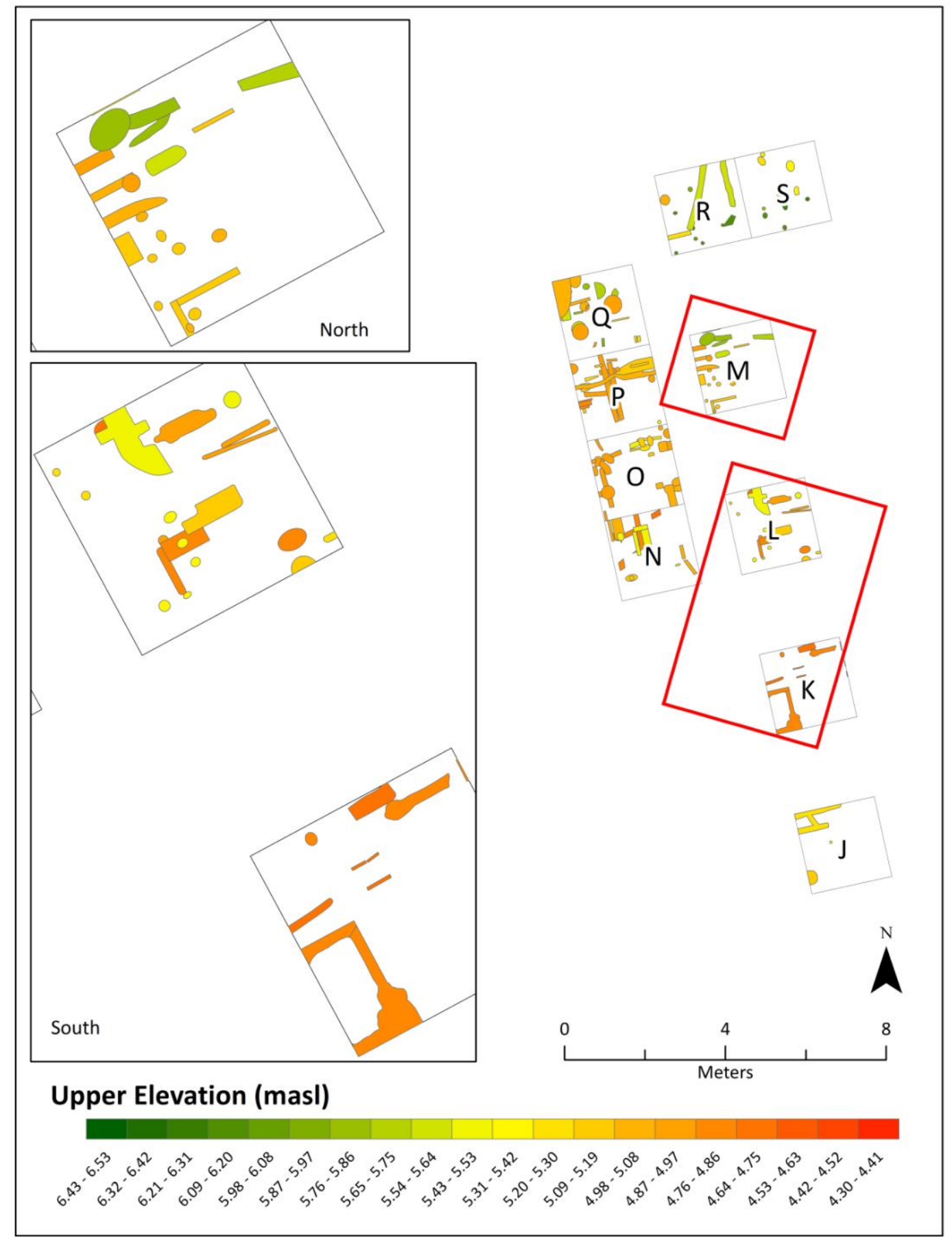

Figure 20. Upper elevation of architectural features in central areas, Cathlapotle House 4. 
superimposed sand floors, variation in elevation noted in the central area may be associated with these new floors. Thus, in House 4 feature elevations in the center likely reflect relative age. Overall, there is evidence of multiple replacements of medium sized planks in the center area (likely representing ridge beam supports) and some changes in elevation, with occasional features with higher upper elevations occurring (Table 10, Figure 20). Additionally, the row of high elevation plankmolds in the north center of House 4 (Unit M) indicates that the northern wall of this structure may have been reset late in the house's uselife.

Table 10. Vertical and Horizontal Positioning of Architectural Features, Cathlapotle House 4.

\begin{tabular}{|c|c|c|c|}
\hline $\begin{array}{l}\text { General } \\
\text { Area }\end{array}$ & $\begin{array}{l}\text { Specific } \\
\text { Area }\end{array}$ & Units & Observations \\
\hline \multirow[t]{2}{*}{$\begin{array}{l}\text { Walls } \\
\text { (Figure 19) }\end{array}$} & $\begin{array}{l}\text { West } \\
\text { wall }\end{array}$ & $\mathrm{N}, \mathrm{O}, \mathrm{P}, \mathrm{Q}$ & $\begin{array}{l}\text { The north area of the west wall is dominated by medium to large } \\
\text { posts, while other areas along the wall contained many } \\
\text { plankmolds. Features along this wall exhibit some variation in } \\
\text { elevation. Small clusters of features with higher upper elevations } \\
\text { are noted in Units N and Q. }\end{array}$ \\
\hline & $\begin{array}{l}\text { North } \\
\text { wall }\end{array}$ & $\mathrm{R}, \mathrm{S}$ & $\begin{array}{l}\text { This unit contains few large architectural features, but they tend } \\
\text { to vary slightly in upper elevation. }\end{array}$ \\
\hline \multirow[t]{2}{*}{$\begin{array}{l}\text { Center } \\
\text { (Figure 20) }\end{array}$} & North & M & $\begin{array}{l}\text { A row of features in the north has consistently higher elevations } \\
\text { than those in the south of the unit. These features may represent a } \\
\text { reset wall constructed later in the house's occupation, or possibly } \\
\text { an interior partition. }\end{array}$ \\
\hline & South & $\mathrm{L}, \mathrm{K}, \mathrm{J}$ & $\begin{array}{l}\text { Upper elevations of southern central features are deeper than } \\
\text { those to the north, even when accounting for differences in } \\
\text { topography. }\end{array}$ \\
\hline
\end{tabular}

In this question, episodes of feature replacement were used to investigate continuity in house architecture by examining replacement episodes in wall planks and beam supports at both sites. At both sites, fine-scale maps show many examples of redundantly-placed features, suggesting that structural element replacement occurred regularly and that placement of elements remained relatively stable over time. At Meier, features in the walls vary somewhat in elevation, while those in hearth areas remain essentially the same. At Cathlapotle House 1, this same trend of greater variation in 
elevation in walls as opposed to ridge beam supports is noted. In Cathlapotle House 4, variation in walls and central areas was comparable. Overall, these data show that structural elements were often replaced in similar locations. In walls, structural element position may have varied somewhat with depth over time. In interior areas, structural elements were also often replaced, however, depth was usually more carefully maintained. This indicates that continuity of house layout was important in interior areas.

\section{(4) Plankhouse orientation was consistent through time.}

This question examined whether house alignment (which is a proxy for physical appearance) remained stable through time. Changes in orientation were investigated using maps of plankmold orientation, the Spearman's rank order correlation, and linear directional means analysis (LDM). At Meier, I selected plankmolds parallel to the house's west wall to evaluate any evidence that the house shifted in orientation (Figure 21). No correlations are noted between depth and orientation (Table 11), and the LDM test indicated that plankmold direction is similar in all depths (Table 12). To additionally evaluate evidence that the Meier House shifted over time, I selected the plankmolds that were classified as part of hearth facilities (Figure 21), many of which likely represent ridge beam supports. No correlation is noted between orientation and upper elevation (Table 11). LDM for the three elevation groups exhibit a significant shift for the central elevation group, showing that as a whole, plankmolds in this group are oriented significantly differently than plankmolds in the upper and lower groups (Table 12). However, sample size for each group is low, so this result could be impacted by several plankmolds with outlier orientations. 
Table 11. Spearman's Rank Order Test for Groups of Plankmolds.

\begin{tabular}{llcc}
\hline & Location & Count & Spearman's Rank Order \\
\hline \multirow{2}{*}{ Meier } & West wall & 9 & $\mathrm{p}>.5, \mathrm{r}_{s}=0.083$ \\
& Central area & 28 & $\mathrm{p}>.5, \mathrm{r}=-0.103$ \\
\hline Cathlapotle House 1 & East and west planks & 26 & $.1>\mathrm{p}>.05 . \mathrm{r}=-0.371$ \\
& Central area & 35 & $\mathrm{p}>.5, \mathrm{r}=-0.08$ \\
\hline Cathlapotle House 4 & East and west planks & 51 & $\mathrm{p}>.1, \mathrm{r}=-0.171$ \\
& North and south planks & 15 & $\mathrm{p}>.5, \mathrm{r}=0.169, \mathrm{n}=15$ \\
\hline
\end{tabular}

Table 12. Linear Directional Means for Groups of Plankmolds by Depth.

\begin{tabular}{|c|c|c|c|c|}
\hline & Location & Elevation & Count & LDM \\
\hline \multirow[t]{6}{*}{ Meier } & West wall & 35 or less $\mathrm{cmbd}$ & 4 & 166 \\
\hline & & $35.01-47 \mathrm{cmbd}$ & 3 & 172 \\
\hline & & 47.01 or more $\mathrm{cmbd}$ & 2 & 161 \\
\hline & Central area & 78 or less cmbd & 7 & 91 \\
\hline & & $78.1-98 \mathrm{cmbd}$ & 9 & 29 \\
\hline & & 98.1 or more $\mathrm{cmbd}$ & 11 & 81 \\
\hline \multirow[t]{6}{*}{ Cathlapotle House 1} & East and west walls & More than 5.86 masl & 6 & 160 \\
\hline & & 5.71-5.86 masl & 8 & 150 \\
\hline & & Less than 5.71masl & 12 & 146 \\
\hline & Central area & More than 5.77 masl & 9 & 52 \\
\hline & & $5.59-5.77$ masl & 12 & 60 \\
\hline & & Less than 5.59 masl & 14 & 58 \\
\hline \multirow[t]{6}{*}{ Cathlapotle House 4} & East and west planks & More than 5.14 masl & 18 & 156 \\
\hline & & $4.86-5.14$ masl & 15 & 155 \\
\hline & & Less than 4.86 masl & 18 & 166 \\
\hline & North and south planks & More than 5.10 masl & 4 & 61 \\
\hline & & 4.92-5.09 masl & 6 & 61 \\
\hline & & Less than 4.92 masl & 5 & 58 \\
\hline
\end{tabular}

For Cathlapotle House 1, I selected plankmolds parallel to the house's east and west wall (Figure 22). A Spearman's rank order correlation shows a potential correlation between upper elevation and orientation, although results are not statistically significant (Table 11). Results of a LDM test also suggest that orientation may have shifted very slightly over time (Table 12). I also examined plankmolds in central areas of Cathlapotle House 1 (Figure 22). A Spearman's rank order correlation does not show statistically significant correlations (Table 11), and no large shift in LDM was noted (Table 12).

For Cathlapotle House 4, I selected the plankmolds running east-west (Figure 23). A Spearman's rank order correlation shows no significant correlation between orientation and depth (Table 11). Results of the LDM test show that plankmolds in the top two 
elevation groups are somewhat different than the lower group, suggesting that the house may have shifted slightly from its beginning orientation (Table 12). For Cathlapotle House 4, LDM were also calculated for plankmolds running generally north-south (Figure 23). No correlation between depth and orientation is noted (Table 11). Overall, results of LDM analysis suggest plankmold orientation within House 4 was remarkably stable (Table 12).

In summary, for all three houses investigated, statistical tests and examination of GIS maps provided little conclusive evidence of shifting orientation. At Meier, central plankmolds may have shifted significantly in the middle elevations, but returned to a similar orientation. However, sample size was small so this result is tentative. At

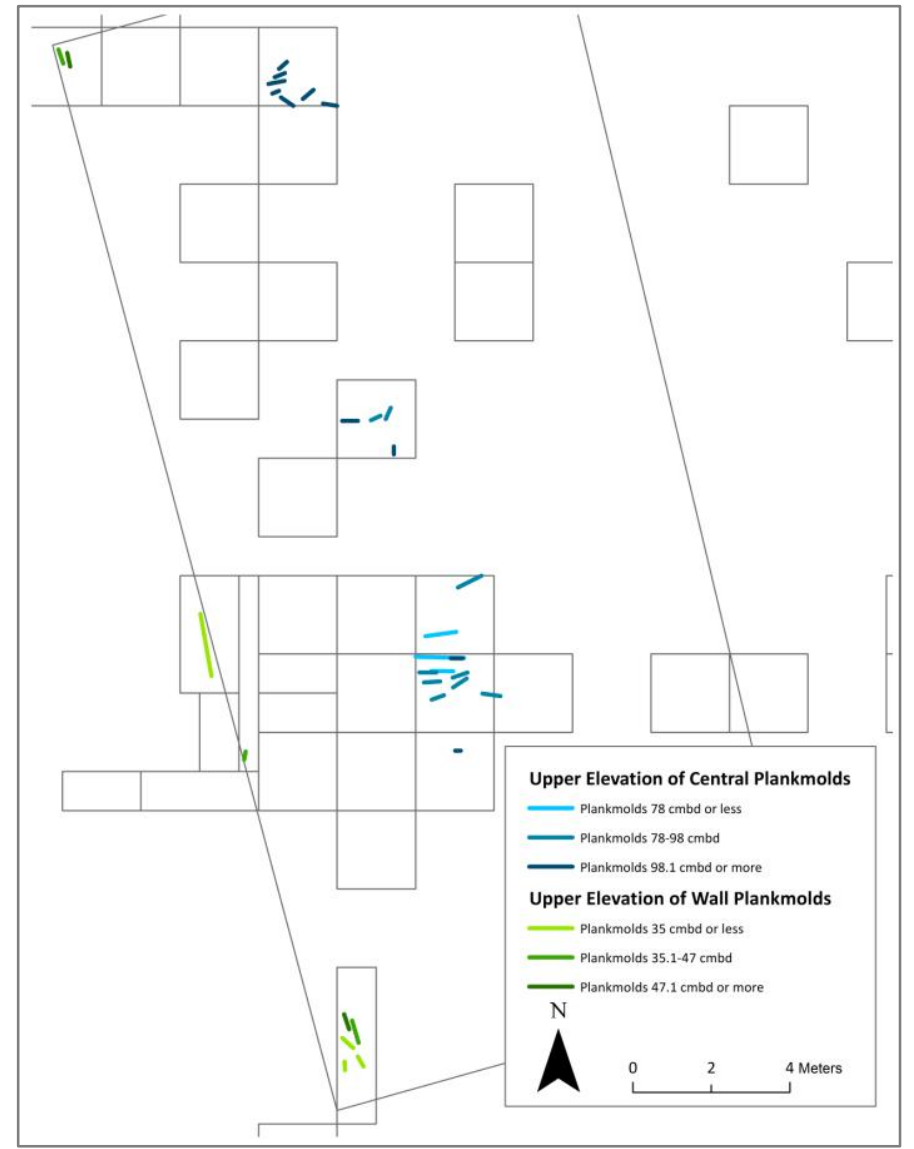

Figure 21. Plankmolds in wall and central areas at Meier by upper elevation. 


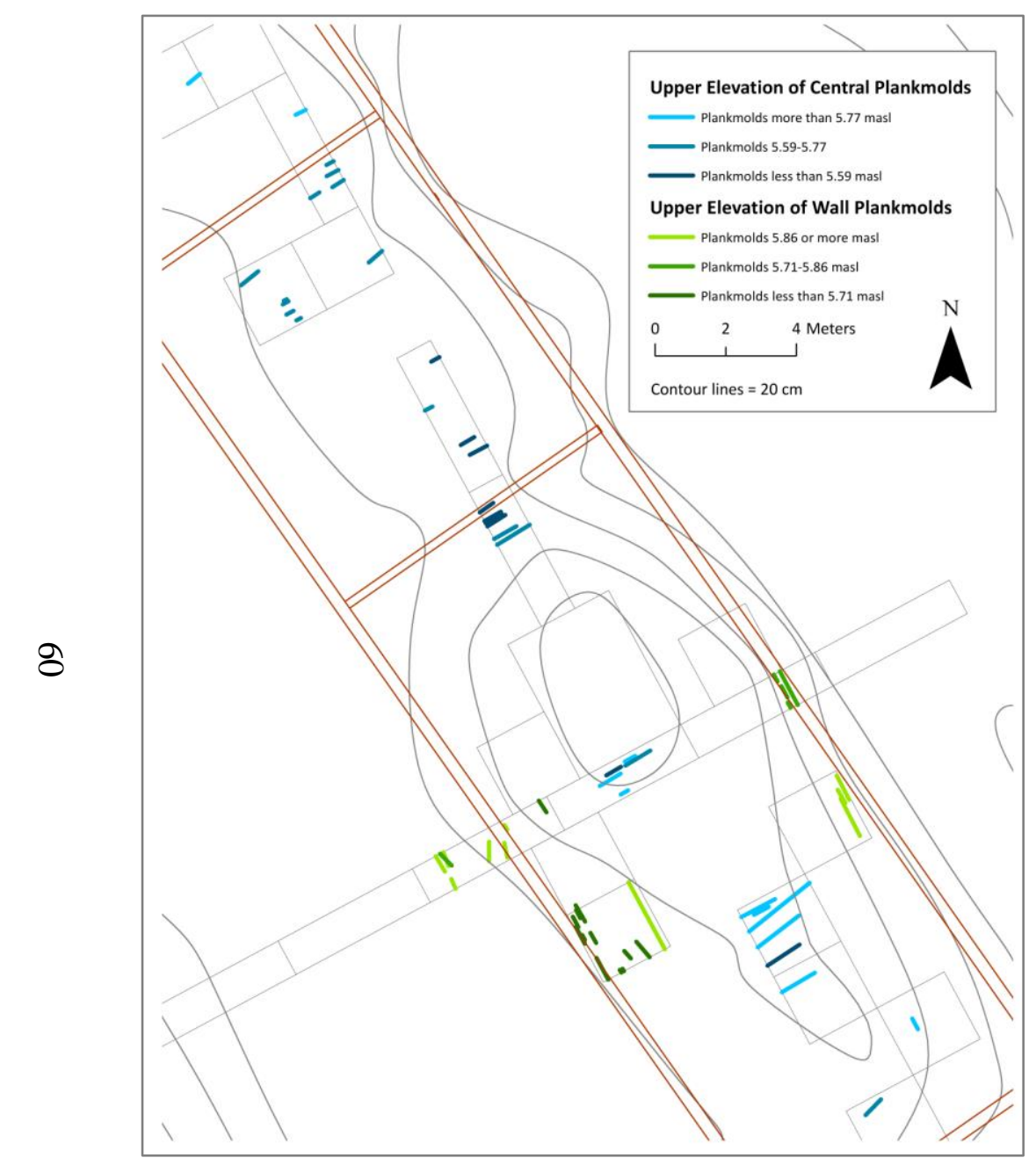

Figure 22. Plankmolds in walls and central area at Cathlapotle House 1 by upper elevation.

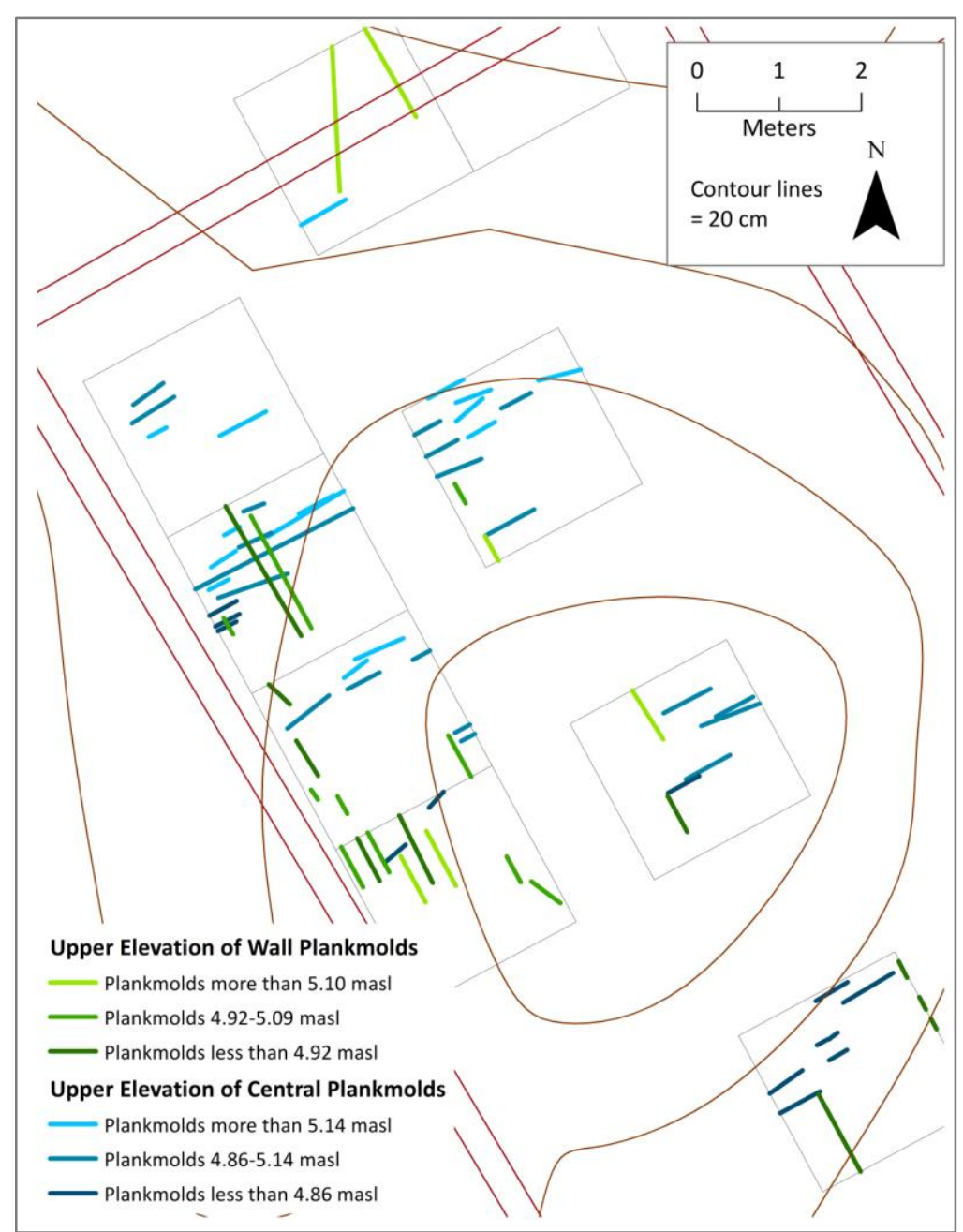

Figure 23. Plankmolds in walls and central area at Cathlapotle House 4 by upper elevation. 
Cathlapotle House 1, plankmolds in walls may have shifted slightly over time, although statistical tests were not significant. Overall, maps and tests indicate continuity of plankmold orientation over depth, and thus stability in house orientation and structure. However, small sample size and the sensitivity of these tests to outliers make interpretation difficult.

(5) Similar structural elements were used in Cathlapotle House 1 and 4, and in Compartments B-D of House 1.

At Cathlapotle, complete feature metrics from Houses 1 and 4 were compared using the Mann-Whitney test (Table 13). Plankmolds from House 4 are significantly longer than in House 1, although there are no significant differences in width. However, many more plankmolds in House 1 are under $20 \mathrm{~cm}$ in maximum length than in House 4, and may have been used for interior furnishings rather than architecture. When only plankmolds over $20 \mathrm{~cm}$ in maximum length were included in analysis, there are no significant differences in plankmold length. Posthole and postmold dimensions were compared between Houses 1 and 4, with no significant differences in length or width for either of these categories. For the combined post category, length and width are not significantly different between the houses, although some evidence suggests that features in House 4 were larger. Overall, results of comparisons between Cathlapotle Houses 1 and 4 do not reveal significant differences in feature size.

Features were also compared within compartments of House 1. Complete plankmolds were found only in Compartments C and D. There are no significant differences in length $(U=74.5, p>.5, n=32)$ or width $(U=61, p>.1, n=32)$ for plankmolds 
in the two compartments. For postmolds, no significant differences are noted between the three compartments for length $(\mathrm{H}(2)=.716, \mathrm{p}>.5, \mathrm{n}=108)$ or width $(\mathrm{H}(2)=.024, \mathrm{p}>.5$, $\mathrm{n}=108$ ). Statistics for postholes were not completed, as complete postholes were found in only Compartment D.

Table 13. Results of Mann-Whitney Test for Differences in Feature Length and Width between Cathlapotle House 1 and 4.

\begin{tabular}{|c|c|c|c|c|c|c|}
\hline & & \multirow[b]{2}{*}{ Count } & \multicolumn{2}{|l|}{ Median } & \multicolumn{2}{|l|}{ Median } \\
\hline & & & Length $(\mathrm{cm})$ & Test Results & Width $(\mathrm{cm})$ & Test Result \\
\hline \multirow{2}{*}{$\begin{array}{l}\text { All } \\
\text { plankmolds }\end{array}$} & House 1 & 32 & 21 & $\mathrm{U}=191, \mathrm{p}=.001$ & 6 & $\mathrm{U}=300.5, \mathrm{p}>.1$ \\
\hline & House 4 & 24 & 38.5 & & 7 & \\
\hline \multirow{2}{*}{$\begin{array}{l}\text { Plankmolds } \\
>20 \mathrm{~cm}\end{array}$} & House 1 & 18 & 38 & $\mathrm{U}=134.5, \mathrm{p}>.1$ & 9 & $\mathrm{U}=166, \mathrm{p}>.5$ \\
\hline & House 4 & 22 & 39.5 & & 7 & \\
\hline \multirow[t]{2}{*}{ Postholes } & House 1 & 36 & 8 & $\mathrm{U}=380, \mathrm{p}>.1$ & 7 & $\mathrm{U}=369.5, \mathrm{p}>.1$ \\
\hline & House 4 & 22 & 9 & & 8 & \\
\hline \multirow[t]{2}{*}{ Postmolds } & House 1 & 108 & 9 & $\mathrm{U}=3174, \mathrm{p}>.1$ & 8 & $\mathrm{U}=3136, \mathrm{p}>.1$ \\
\hline & House 4 & 65 & 11 & & 10 & \\
\hline \multirow{2}{*}{$\begin{array}{l}\text { Combined } \\
\text { posts }\end{array}$} & House 1 & 144 & 9 & $\mathrm{U}=5776, .1>\mathrm{p}>.05$ & 8 & $\mathrm{U}=5677, .1>\mathrm{p}>.05$ \\
\hline & House 4 & 87 & 10 & & 8.8 & \\
\hline
\end{tabular}

Significant results are bolded. Only complete features included.

(6) Structural elements differ between facilities.

Morphological attributes of feature classes were investigated between

architectural facilities, although small sample size impacted comparisons between some facilities (see Tables A-7 and A-8 for descriptive statistics). Only features with complete horizontal measurements were used. At Meier, four major feature facilities were used for classification: hearth, cellar, bench and wall. For plankmolds, maximum length does not differ significantly when all four facilities are compared $(H(3)=5.838, p>.1, n=71)$. Width of plankmolds does differ significantly between facilities $(H(3)=21.637, p=.001$, $\mathrm{n}=71$ ), likely driven by larger widths of plankmolds in walls. When plankmold metrics in the four different facilities were compared one-to-one, several differences are noted (Table 14). Plankmolds in walls are wider than in other facilities, and plankmolds in hearths are longer and wider than those in cellar or bench facilities. 
Complete combined posts larger than $7 \mathrm{~cm}$ were compared for all facilities at Meier. No statistically significant differences are noted when comparing all groups for maximum length $(H(3)=6.384, .1>p>.05, n=86)$ or width $(H(3)=6.441, .1>p>.05$, $\mathrm{n}=86$ ). One-to-one comparisons found that posts in walls are significantly larger than those in hearths (Table 14). In summary, at Meier, features are largest in walls and hearths, likely reflecting the prevalence of major structural elements such as wall planks and roof supports in these facilities.

Table 14. Differences in Feature Metrics in Facilities, Meier. (Only Results where $p<.1$ Included).

\begin{tabular}{llll}
\hline Feature Class & Measurement & Result & \\
\hline Plankmolds & Length & Hearth $>$ Bench & $\mathrm{U}=151.5, .1>\mathrm{p}>.05, \mathrm{n}=42$ \\
& & Hearth $>$ Cellar & $\mathrm{U}=147, \mathrm{p}<.05, \mathrm{n}=44$ \\
& Width & Wall $>$ Bench & $\mathrm{U}=13.5, \mathrm{p}<.005, \mathrm{n}=27$ \\
& & Wall $>$ Cellar & $\mathrm{U}=8.5, \mathrm{p}<.005, \mathrm{n}=29$ \\
& Wall $>$ Hearth & $\mathrm{U}=31.5, .1>\mathrm{p}>.05, \mathrm{n}=27$ \\
& & Hearth $>$ Bench & $\mathrm{U}=146, .1>\mathrm{p}>.05, \mathrm{n}=42$ \\
& & Hearth $>$ Cellar & $\mathrm{U}=89, \mathrm{p}<.001, \mathrm{n}=44$ \\
& & Bench $>$ Cellar & $\mathrm{U}=159, \mathrm{p}<.05, \mathrm{n}=44$ \\
Posts & Length & Wall $>$ Hearth & $\mathrm{U}=98, \mathrm{p}<.05, \mathrm{n}=39$ \\
& Width & Wall $>$ Hearth & $\mathrm{U}=93, \mathrm{p}<.05, \mathrm{n}=39$ \\
\hline
\end{tabular}

A chi square test was performed to compare proportions of plankmolds, combined post features, and pegs (posts $<7 \mathrm{~cm}$ ) in bench, cellar, wall and hearth facilities at Meier. Feature classes distributions differ between facilities $\left(\chi^{2}=52.232(6), \mathrm{p}=.001, \mathrm{n}=271\right)$. Pegs (posts smaller or equal to $7 \mathrm{~cm}$ in length) were more prevalent in hearth facilities (Figure 24). When pegs were removed from analyses, planks and posts are not distributed differently within architectural facilities $\left(\chi^{2}=1.002(5), \mathrm{p}>.5, \mathrm{n}=154\right)$.

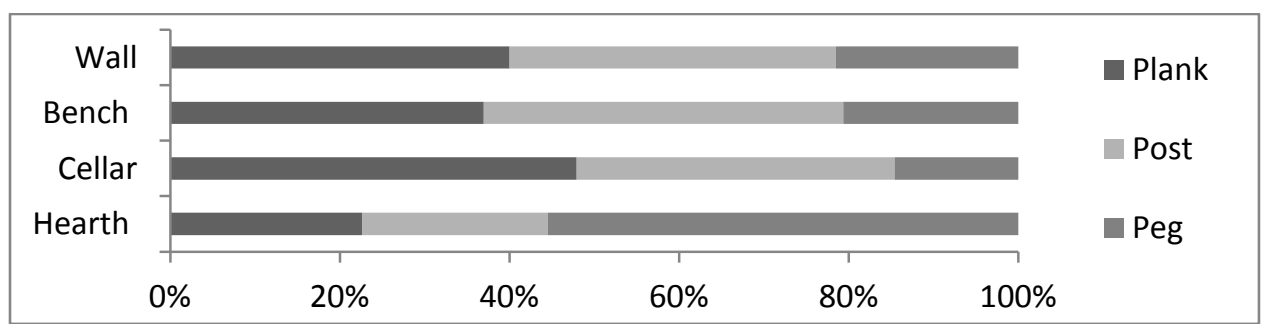

Figure 24. Distribution of selected features across plankhouse facilities, Meier. 
At Cathlapotle, plankmolds, postmolds, postholes and combined posts were compared between hearth, bench and wall facilities. I included features from both House 1 and House 4, as separating houses would decrease sample size. Plankmold metric attributes were compared across facilities (Table 15). For plankmolds, maximum length $(\mathrm{H}(3)=11.127, \mathrm{p}<.005, \mathrm{n}=60)$ and width $(\mathrm{H}(3)=11.620, \mathrm{p}<.005, \mathrm{n}=60)$ differ significantly across the three facilities, with plankholds in hearths longer and wider than in other facilities.

For postholes, there are significant differences in width between the three facilities $(\mathrm{H}(3)=9.208, \mathrm{p}<.05 \mathrm{n}=63)$. In a one-to-one comparison, postholes are longer in benches than in hearths. Neither postmold length $(H(3)=1.081, p>.5, n=184)$ or width $(\mathrm{H}(3)=2.828, \mathrm{p}>.1, \mathrm{n}=184)$ differ significantly between the three facilities. However, when postmolds are compared one-to-one, those in walls are significantly larger than in hearths (Table 15). When postmold and posthole categories are combined, post length did not differ significantly between the facilities $(\mathrm{H}(3)=4.802, .1>\mathrm{p}>.05, \mathrm{n}=247)$, although there is significant difference in post width $(\mathrm{H}(3)=8.450, \mathrm{p}<.05, \mathrm{n}=247)$. In one-to-one comparisons combined posts are larger in walls than in hearths (Table 15). Overall, at Cathlapotle planks are largest in hearths and posts are largest in walls.

Table 15. Differences in Feature Metrics in Facilities, Cathlapotle (Only Results where p<.1 Included).

\begin{tabular}{llll}
\hline Feature Class & Measurement & Result & \\
\hline Plankmolds & Length & Hearth $>$ Wall & $\mathrm{U}=187.500, \mathrm{p}<.005, \mathrm{n}=57$ \\
& Width & Hearth $>$ Wall & $\mathrm{U}=201.500, \mathrm{p}<.005, \mathrm{n}=57$ \\
Postholes $(>7 \mathrm{~cm})$ & Length & Bench $>$ Hearth & $\mathrm{U}=222.5, \mathrm{p}<.005, \mathrm{n}=28$ \\
Postmolds $(>7 \mathrm{~cm})$ & Length & Wall $>$ Hearth & $\mathrm{U}=1207, \mathrm{p}<.05, \mathrm{n}=116$ \\
& Width & Wall $>$ Hearth & $\mathrm{U}=1122.5, \mathrm{p}<.01, \mathrm{n}=116$ \\
All posts & Length & Wall $>$ Hearth & $\mathrm{U}=5040.5, \mathrm{p}<.05, \mathrm{n}=182$ \\
& Width & Wall $>$ Hearth & $\mathrm{U}=4763, \mathrm{p}=.006, \mathrm{n}=182$ \\
\hline
\end{tabular}


The distribution of feature types among facilities at Cathlapotle was investigated with a chi square test. This test compared the distribution of plankmolds, postmolds, postholes and pegs in hearth, bench and wall facilities. As seen in Figure 25, feature classes differ in distribution across the three facilities $\left(\chi^{2}=53.741(6), \mathrm{p}=.001, \mathrm{n}=410\right)$. A significant difference in distribution is also present when pegs are excluded $\left(\chi^{2}\right.$ $=33.952(5), \mathrm{p}=.001, \mathrm{n}=265)$. Distributions of the combined post category and plankmolds between only hearth and wall facilities also differ from expectations $\left(\chi^{2}=24.460(3)\right.$, $\mathrm{p}=.001, \mathrm{n}=247$ ), with more plankmolds present in wall faculties than in hearth facilities.

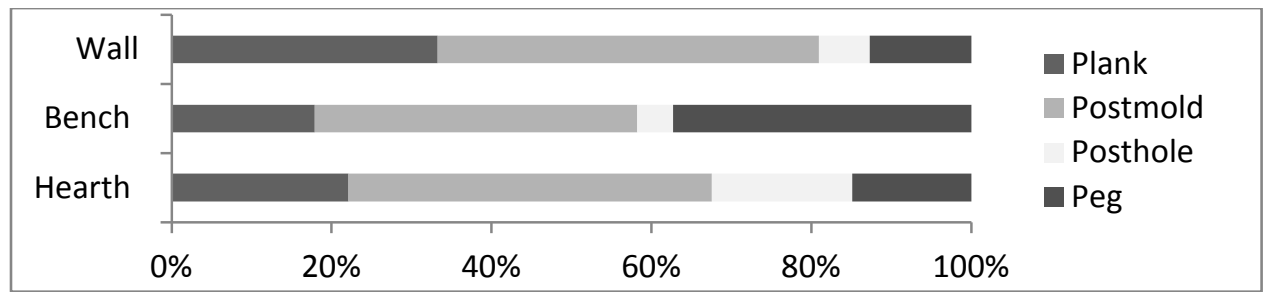

Figure 25. Distribution of selected features across plankhouse facilities, Cathlapotle.

In summary, differences between architectural features in facilities were noted at both sites. At Meier, comparisons of plank and post sizes between facilities show that some differences exist in feature metrics in different areas of the house - features in walls and hearths tend to be larger than those in other facilities. Hearths contain many small posts, which were likely used in drying racks and other food preparation. At Cathlapotle planks are largest in hearth facilities, indicating that large planks were used as ridge beam supports. At both Cathlapotle and Meier, posts are larger in walls than in benches and hearths, suggesting that many small posts were used in these areas for insubstantial interior structures. Plank patterning is different between the two sites. At Meier, wall facilities generally contained larger planks, while at Cathlapotle, hearth facilities did. This points to some differences between interior architecture at Meier and Cathlapotle. 
Overall, distribution analysis suggests that facilities assigned at Cathlapotle are quantifiably distinct in respect to distribution of architectural features. Therefore, these facilities are meaningful designations of different areas in the houses with disparate uses by house occupants. At Meier, there is also evidence to support this conclusion. However, this evidence is not as strong, possibly because of smaller sample size.

\section{(7) Similar structural elements were used at Meier and Cathlapotle.}

In order to assess differences between architecture at the two sites, I compared metrics of complete features. Analysis of length and width for plankmolds, postmolds, postholes and combined posts between Meier and Cathlapotle demonstrate some differences in metrics between the two sites. Table 16 presents comparisons of feature metrics between all complete features at Cathlapotle and Meier as well as comparisons between metrics in both hearth and wall facilities between the sites. Plankmolds at Cathlapotle are significantly longer and wider than those at Meier. Combined posts are significantly wider at Cathlapotle than at Meier, and may also be longer, although not significantly.

Metrics of architectural features were also compared for the two sites within two architectural facilities: hearths and walls. These facilities were selected for analysis because they have the most potential to provide information on architecture and because of large sample size. Several differences were noted between feature metrics in hearth facilities at Meier and Cathlapotle. Plankmolds are significantly longer at Cathlapotle, and also may be wider, although this result is not significant. Combined posts in hearths are also wider at Cathlapotle, and postholes also may be wider, although not significantly. Fewer differences were observed for feature metrics in wall facilities between the two 
sites, this may be because of very low sample size for complete features at Meier.

Plankmolds were significantly longer at Cathlapotle than at Meier. No other test result showed significant metric differences for wall features.

Table 16. Comparison of Lengths and Widths of Features at Cathlapotle and Meier.

\begin{tabular}{|c|c|c|c|c|c|c|}
\hline & \multicolumn{3}{|c|}{ Length $(\mathrm{cm})$} & \multicolumn{3}{|c|}{ Width $(\mathrm{cm})$} \\
\hline & $\begin{array}{l}\text { Cathlapotle } \\
\text { Median }\end{array}$ & $\begin{array}{l}\text { Meier } \\
\text { Median }\end{array}$ & $\begin{array}{c}\text { Mann-Whitney } \\
\text { Test }\end{array}$ & $\begin{array}{l}\text { Cathlapotl } \\
\text { e Median }\end{array}$ & $\begin{array}{l}\text { Meier } \\
\text { Median }\end{array}$ & $\begin{array}{c}\text { Mann-Whitney } \\
\text { Test }\end{array}$ \\
\hline \multicolumn{7}{|c|}{ All complete features } \\
\hline Plankmold & $\underline{30 \quad(n=64)}$ & $14(\mathrm{n}=74)$ & $\begin{array}{c}\mathrm{U}=54858, \mathrm{z}= \\
-4.013, p=.000\end{array}$ & $7(n=64)$ & $5(n=74)$ & 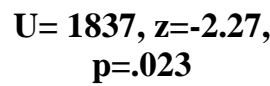 \\
\hline Postmold & $13(n=143)$ & $16(n=11)$ & $\begin{array}{c}\mathrm{U}=786.5, \\
\mathrm{z}=.863, \mathrm{p}>.1\end{array}$ & $\begin{array}{c}10 \\
(n=143)\end{array}$ & $8(n=11)$ & $\begin{array}{c}\mathrm{U}=786.5 \\
\mathrm{z}=-.309 \mathrm{p}>.5\end{array}$ \\
\hline Posthole & $10(n=44)$ & $10(n=67)$ & $\begin{array}{c}\mathrm{U}=1474 \\
\mathrm{z}=.045, \mathrm{p}>.5\end{array}$ & $8(n=44)$ & $9(n=67)$ & $\begin{array}{c}\mathrm{U}=1474 \\
\mathrm{z}=1.88, .1>\mathrm{p}>.05\end{array}$ \\
\hline $\begin{array}{l}\text { Combined } \\
\text { posts }\end{array}$ & $12(n=187)$ & $10(n=78)$ & $\begin{array}{c}\mathrm{U}=7293, \mathrm{z}= \\
-1.67, .1>\mathrm{p}>.05\end{array}$ & $\underline{10} \underline{(n=187)}$ & $8(n=78)$ & $\begin{array}{c}\mathrm{U}=7293, \mathrm{z}=-3.36, \\
\mathrm{p}=.001\end{array}$ \\
\hline \multicolumn{7}{|c|}{ Complete features in hearths } \\
\hline Plankmold & $\underline{42(n=20)}$ & $18(n=21)$ & $\begin{array}{c}\mathrm{U}=210, \mathrm{z}=2.73, \\
\mathrm{p}=.006\end{array}$ & $11(n=20)$ & $7(n=21)$ & $\begin{array}{c}\mathrm{U}=1470 \\
\mathrm{z}=1.682, .1>\mathrm{p}>.05\end{array}$ \\
\hline Postmold & $\begin{array}{c}11.25 \\
(n=58)\end{array}$ & $14(n=3)$ & $\begin{array}{c}\mathrm{U}=899, \mathrm{z}=.567 \\
\mathrm{p}>.5\end{array}$ & $\begin{array}{c}8.75 \\
(n=58)\end{array}$ & $8(n=3)$ & $\begin{array}{c}\mathrm{U}=899, \mathrm{z}=-.150 \\
\mathrm{p}>.5\end{array}$ \\
\hline Posthole & $10(n=16)$ & $9.5(n=20)$ & $\begin{array}{c}\mathrm{U}=986.5 \\
\mathrm{z}=.891, \mathrm{p}>.1\end{array}$ & $8(n=16)$ & $7(n=20)$ & $\begin{array}{c}\mathrm{U}=986.5, \mathrm{z}= \\
-1.862, .1>p>.05\end{array}$ \\
\hline $\begin{array}{l}\text { Combined } \\
\text { posts }\end{array}$ & $11(n=74)$ & $10(n=23)$ & $\begin{array}{c}\mathrm{U}=13899.5, \mathrm{z}=- \\
1.416, \mathrm{p}>.1\end{array}$ & $\underline{8.5(n=74)}$ & $7(n=23)$ & $\begin{array}{c}\mathrm{U}=13899, \\
\mathrm{z}=-\mathbf{2 . 9 8}, \mathrm{p}=.003\end{array}$ \\
\hline \multicolumn{4}{|c|}{ Complete features in walls } & & & \\
\hline Plankmold & $\underline{20(n=19)}$ & $9(n=3)$ & $\begin{array}{c}\mathrm{U}=109, \mathrm{z}= \\
-2.009, p=.045\end{array}$ & $6(n=19)$ & $8(n=3)$ & $\begin{array}{c}\mathrm{U}=109, \mathrm{z}=1.244, \\
\mathrm{p}>.1\end{array}$ \\
\hline Postmold & N/A* & N/A* & $\mathrm{N} / \mathrm{A} *$ & N/A* & $\mathrm{N} / \mathrm{A} *$ & $\mathrm{~N} / \mathrm{A}^{*}$ \\
\hline Posthole & $10(n=14)$ & $10(n=6)$ & $\begin{array}{c}\mathrm{U}=147, \\
\mathrm{z}=-.412, \mathrm{p}>.5\end{array}$ & $10(n=14)$ & $8(n=6)$ & $\begin{array}{c}\mathrm{U}=147, \mathrm{z}=-1.402, \\
\mathrm{p}>.1\end{array}$ \\
\hline $\begin{array}{l}\text { Combined } \\
\text { posts }\end{array}$ & $\begin{array}{c}10.5(\mathrm{n}= \\
50)\end{array}$ & $10.5(n=8)$ & $\begin{array}{c}\mathrm{U}=1966.5 \\
\mathrm{z}=.440, \mathrm{p}>.5\end{array}$ & $10(n=50)$ & $9(n=8)$ & $\begin{array}{c}\mathrm{U}=1966.5 \\
\mathrm{z}=-.090, \mathrm{p}>.5\end{array}$ \\
\hline
\end{tabular}

Subsequently, feature size classes were compared between each site using four size classes (Class 2: 7.1-20 cm, Size Class 3: 20.1-40 cm, Class 4: 40.1-70 cm, Class 5: > $70 \mathrm{~cm}$ ). Size Class 1 was excluded from analysis these features are likely unrelated to house structure. The chi square test was performed for combined posts and plankmolds. Separate tests were run for only complete features, and for all features. No difference in 
size class distribution is noted for complete posts between Meier and Cathlapotle (Figure $26),\left(\chi^{2}(3)=2.46, p>.5, n=274\right)$. No significant difference in distribution was found when all posts (complete and incomplete) were considered, although some difference may be present $\left(\chi^{2}(3)=6.44, .1>p>.05, n=407\right)$. When Class 2 posts are removed from analysis and all posts (incomplete and complete) are considered, there is a difference in distribution of size classes between the two sites $\left(\chi^{2}(2)=6.48, p=.039, n=150\right)$. More Class 3 posts were noted at Cathlapotle than expected and more Class 4 posts were noted at Meier than expected.

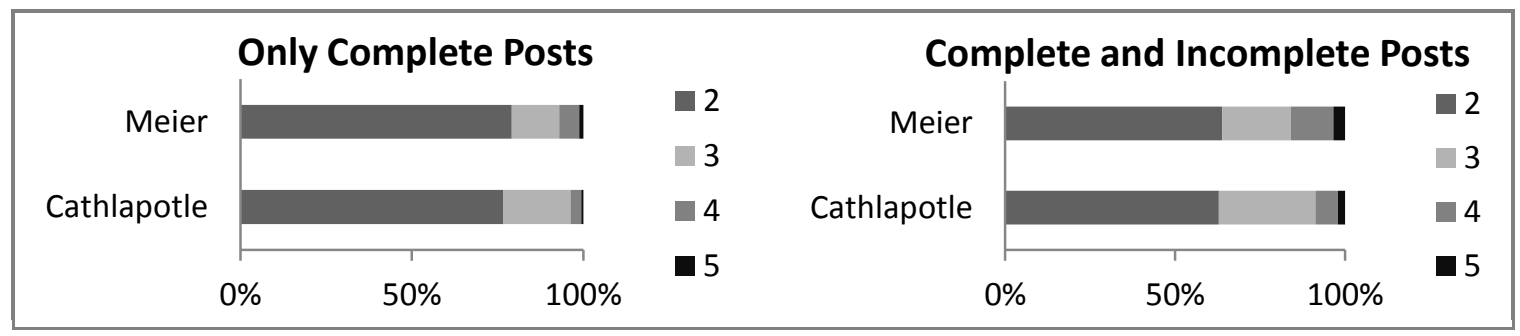

Figure 26. Combined posts by size class, Cathlapotle and Meier.

For plankmold size class between the two sites, test results demonstrate a clear difference in distribution. This is true whether all planks are considered $\left(\chi^{2}(4)=38.1, p=\right.$ $0.000, n=347)$, or whether only complete planks are considered $\left(\chi^{2}(4)=18.0, p=0.001\right.$, $\mathrm{n}=138$ ). This pattern remains when only planks from Meier and Cathlapotle House 1 are compared $\left(\chi^{2}(4)=12.43, \mathrm{p}=0.006, \mathrm{n}=219\right)$. There are more Class 2 plankmolds at Meier than expected, and more Class 3 and 4 plankmolds at Cathlapotle (Figure 27).

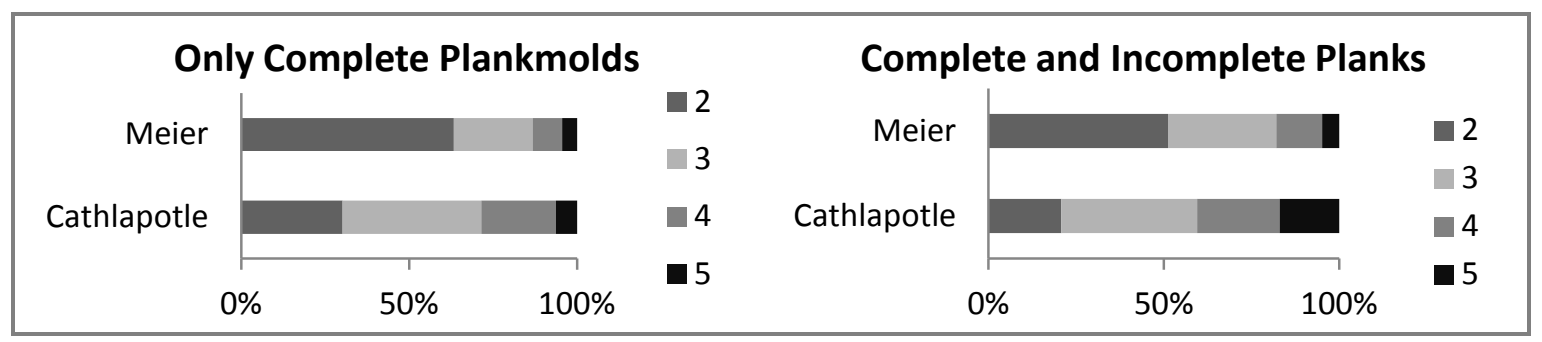

Figure 27. Plankmolds by size class, Cathlapotle and Meier. 
Furthermore, in all facilities, Meier contains a higher percentage of planks compared to posts $(>7 \mathrm{~cm})$ than Cathlapotle across all hearth, bench and wall facilities (Figure 28). Hence, planks may have been used for architecture or lining storage pits more often at Meier than at Cathlapotle.

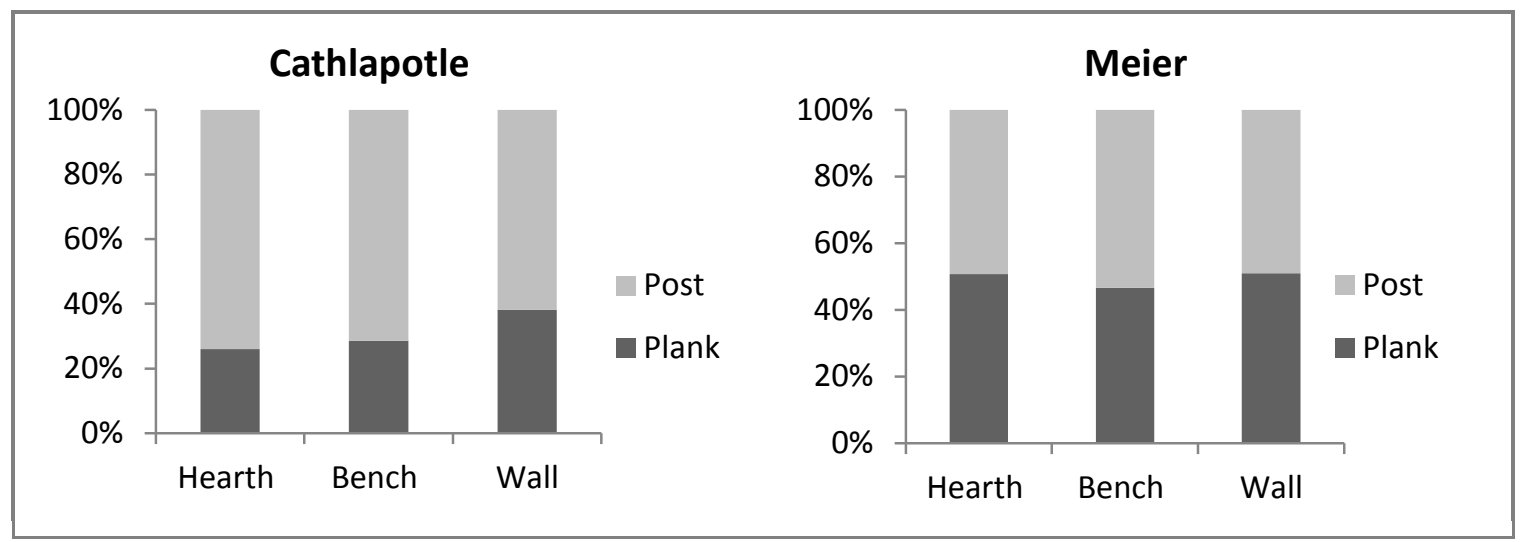

Figure 28. Distribution of plank and post feature $(>7 \mathrm{~cm})$ across facilities.

In summary, results suggest some differences in structural elements between the two sites. Planks are larger in both wall and hearth facilities at Cathlapotle than at Meier. Additionally, there are more planks of larger size classes at Cathlapotle than at Meier. These results show that more large planks may have been used at Cathlapotle than at Meier. Comparison of feature classes also suggests that, in general, planks were used more often in houses at Meier than at Cathlapotle. Taken together, these results suggest that minor structural differences existed between houses and Meier and Cathlapotle, despite their proximity. 


\section{Chapter 6: Results of Plankhouses Labor Literature Review}

In Chapter 7, architectural features are used to investigate questions regarding plankhouse building and repair, such as amount of trees required for construction activities, person hours involved in various tasks, and organization of labor. However, since the archaeological record at Meier and Cathlapotle cannot provide information regarding many aspects of house morphology and activities involved in plankhouse production, it is also necessary to consult other sources. The first section of this chapter summarizes historical, ethnographic and archaeological literature regarding plankhouse production activities. The second section presents environmental and forestry data on cedar, enabling labor estimates to be extended to resource acquisition costs.

\section{$\underline{\text { Plankhouse Construction and Maintenance }}$}

\section{Historical Accounts and Ethnographies of Plankhouse Construction and Maintenance}

Although house form on the Northwest Coast is well-researched, less is recorded regarding the processes of building these structures. However, some historical documents and ethnographies provide descriptions of labor tasks that are related to constructing and maintaining the dwellings. The following ethnographies and historical sources were consulted in this discussion: Boas' (1916) description of Tsimshian tree felling and plank spitting based of notes of Henry Tate; Drucker's (1966) summary of traits associated with construction and tree felling in the central and northern coast; Goddard's (1972) ethnography of various central and northern groups in the early twentieth century; Jewitt's (1987) memoir of life on western Vancouver Island from 1803-1805; Koppert's (1930) interviews with Clayoquot (Tla-o-qui-aht First Nation) elders in 1923 on western 
Vancouver Island; Niblack’s (1970) volume on northern British Columbia and southeastern Alaska groups based on his observations from 1885-1887; and Wilson's (1866:287) description of structural element morphology and house architecture on Vancouver Island. These accounts demonstrate that acquiring materials for plankhouses was a substantial task.

Beams and posts were made from logs that were usually felled, but were sometimes acquired from downed trees. Offering a prayer prior to felling was customary (Boas 1921:619; Mauze 1998). Large trees were felled using chisels, wedges, mauls and hand hammers, as well as the strategic application of fire and systems of scaffolding. Jewitt (1987:93) notes that three workers took 2-3 days to fell large trees, which was a "slow and tedious process". The excess top portion and tree branches were removed from the log, and bark was stripped from the trunk. Logs were then floated down rivers and streams to the village. In addition to manpower, a combination of skidding and ropes was used to transport logs to the watercourse and from the beach to the house building site.

Koppert (1930:10-11) provides a description of obtaining cedar for buildings:

\begin{abstract}
Nine or ten men go into the woods in search of good cedar trees... These trees are felled near the shore and usually on a grade in order to facilitate their transportation... Sixty or more men pull on the rope. While some men push, others, armed with poles, work on the sides of the log. In this way they lift it and at the same time push it along. By repeated effort they succeed in bringing the log to the water and setting it afloat. It is difficult to specify the time it takes for all this because there are so many variable factors, e.g., the number of men available, the size of the tree, the amount of underbrush, the grade of the land, and the nearness to the water. Ordinarily, it may be said it takes two hundred men about twenty-four hours to 'roll' a good-sized log from where it was felled to the water.
\end{abstract}

Once logs were transported to the village site, they were shaped and adzed. Support posts were notched at the top, providing a place for beams to rest. 
Planks for walls and roofs were split either from large logs using wedges or directly from standing trees. In some regions of the Northwest Coast, roof planks were specially shaped to fit together and prevent rain from entering the building. Jewitt (1987:71) discusses replacing planks:

The planks and boards which they make use of for building their houses, and for other uses, they procure of different lengths as occasion requires, by splitting them out, with hard wooden wedges from pine logs, and afterwards dubbing them down with their chizzels, with much patience, to the thickness wanted, rendering them quite smooth.

To split planks, logs were usually hauled to the village site, although sometimes planks were split where the tree was felled. Newcombe (1902) describes the process of felling trees and splitting planks at the felling site,

A tree of a suitable size was chosen...The tree was then pulled down taking care that the side with the most braches was the uppermost... Once properly on the skids the top of the tree was cut through and removed. Next a long rope of cedar bark was taken and stretched on each side for the whole length of the tree. Notches were now made down the line so marked, dividing the upper portion of the trunk into several sections which were split off with the wedge and sledge hammer (quoted in Turner 2004:82).

During house construction, systems of ropes, scaffolding and complex levers were used to raise posts and beams (Figure 29). An 1866 house raising in British Columbia sketched by Henry Elliot (reproduced in Niblack 1970:375) underscores several important aspects of house raisings: (1) use of skids to move large logs, (2) use of ropes in transportation and beam raising, and (3) large amounts of labor needed to move wooden element. House repair activities are not well documented in historical accounts and ethnographies, although Stewart (1984:46) provides examples of sophisticated and time-consuming techniques for repairing warped or split planks. 


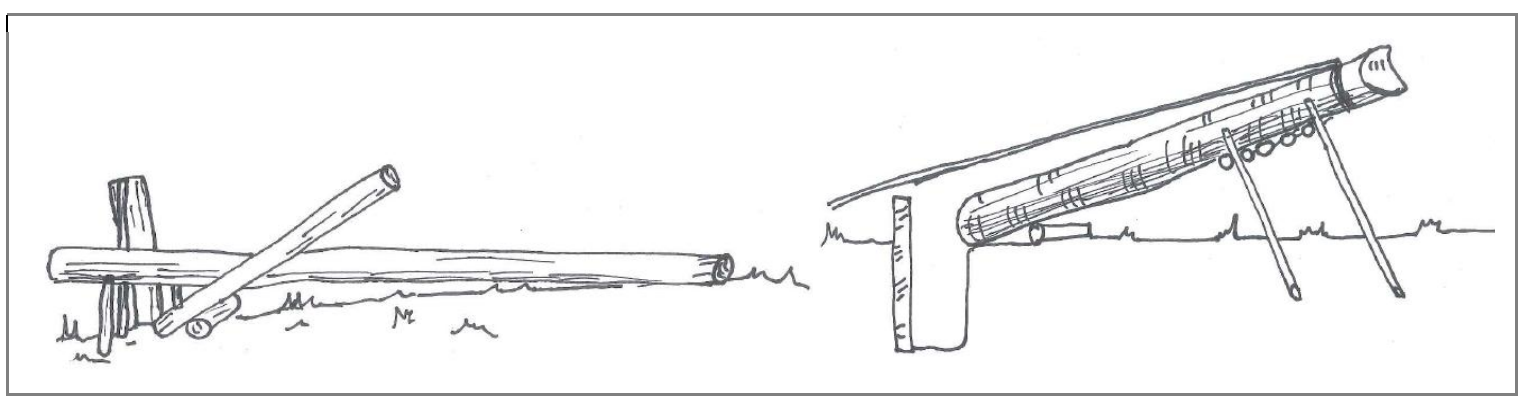

Figure 29. Methods of raising posts and beams: (left) a Kwakiutl method of raising a beam (redrawn from Goddard 1972:29), (right) a Clayoquot method of raising a beam (redrawn from Koppert 1930:14).

Historical documents attest that amassing requisite material and wealth for house building could take years and that house building entailed "great labor and expense" (Niblack 1970:374). These methods required not only physical strength, but also a great deal of coordination and planning.

Archaeology of Plankhouse Construction and Maintenance

Excavation of other plankhouses on the southern and central Northwest Coast provides information regarding architectural feature metrics (Table 17). The most significant archaeological study of household architecture on the Northwest Coast emerged from the remarkable excavation of Makah plankhouses at the Ozette site on the Olympic Peninsula. The Ozette houses were covered by a mudslide in A.D. 1700, resulting in excellent preservation of organic material, including wooden architectural features (Mauger 1978). This allowed researchers to recognize and measure structural elements of buildings, discern how the houses were built, and identify methods of architectural repair. Although some details of house architecture are not applicable to the LCRR, as houses at Ozette were shed-roofed rather than gabled, archaeological data regarding Makah logging and house building techniques allows a rich picture to emerge regarding the myriad activities that were involved in building and repairing plankhouses. 
Table 17. Selected Southern Northwest Coast Plankhouse Architectural Element Descriptions.

\begin{tabular}{|c|c|c|c|c|}
\hline Site & Area & $\begin{array}{l}\text { Architectural } \\
\text { Feature }\end{array}$ & Description & Citation \\
\hline 35-TI-76 & House 8 & Postmolds & $\begin{array}{l}\text { Several posts }<10 \mathrm{~cm} \text { in diameter found } \\
\text { along centerline of house }\end{array}$ & $\begin{array}{l}\text { Losey } \\
2005: 414\end{array}$ \\
\hline $\begin{array}{l}\text { Dionisio } \\
\text { Point }\end{array}$ & House 2 & Postholes & $\begin{array}{l}10 \text { posts }>45 \mathrm{~cm} \text { (likely rafter support } \\
\text { posts), } 15 \text { posts between } 26-45 \mathrm{~cm}, 17 \\
\text { posts between } 16-26 \mathrm{~cm}\end{array}$ & $\begin{array}{l}\text { Grier } \\
\text { 2001:171 }\end{array}$ \\
\hline \multirow[t]{2}{*}{$\begin{array}{l}\text { Middle } \\
\text { Village }\end{array}$} & Entire site & Postholes & $\begin{array}{l}\text { Often } 20 \mathrm{~cm} \text { or less in diameter. Depth } \\
\text { about } 30 \mathrm{~cm} \text {. Often associated with heaths } \\
\text { or bench areas. }\end{array}$ & $\begin{array}{l}\text { Wilson } \\
\text { 2009: } \\
\text { 109, } 200\end{array}$ \\
\hline & Area F Block & Plankmolds & $\begin{array}{l}\text { Width: } 4-6 \mathrm{~cm} \text {, length: } 7-43 \mathrm{~cm} \text {, average } \\
\text { length } 23.8 \mathrm{~cm} .\end{array}$ & \\
\hline \multirow[t]{4}{*}{$\begin{array}{l}\text { Netarts } \\
\text { Sandspit }\end{array}$} & Pit 5 & Plank & $\begin{array}{l}\text { One partially charred, horizontally laid } \\
\text { plank } 70 \mathrm{~cm} \text { tall, base dimensions } 25 \mathrm{x} \\
1.5 \mathrm{~cm}\end{array}$ & $\begin{array}{l}\text { Losey } \\
2005: \\
404-406\end{array}$ \\
\hline & Pit 12 & Corner posts & $\begin{array}{l}18-30 \mathrm{~cm} \text { in diameter, extended deep } \\
\text { below floor midden (at least } 45 \mathrm{~cm} \text { ) }\end{array}$ & \\
\hline & Pit 13 & Postmolds & $\begin{array}{l}\text { At least } 46 \text {, ranging from } 5-27 \mathrm{~cm} \text { in } \\
\text { diameter, } 6-43 \mathrm{~cm} \text { deep below floor fill. }\end{array}$ & \\
\hline & Pit 13 & Plank & Horizontally laid, at least $6.2 \mathrm{~m}$ long. & \\
\hline \multirow[t]{3}{*}{ Ozette } & House $1 \& 2$ & Split planks & $\begin{array}{l}\text { Mean height: } 3.96 \mathrm{~m} \text {, mean width: } .31 \mathrm{~m} \text {, } \\
\text { mean thickness: } 3 \mathrm{~cm}\end{array}$ & $\begin{array}{l}\text { Mauger } \\
\text { 1978: }\end{array}$ \\
\hline & House $1 \& 2$ & $\begin{array}{l}\text { Dressed } \\
\text { planks }\end{array}$ & $\begin{array}{l}\text { Mean height: } 3.92 \mathrm{~m} \text {, mean width } .41 \mathrm{~m} \text {, } \\
\text { mean thickness: } 2.6 \mathrm{~cm}\end{array}$ & 71,73 \\
\hline & House $1 \& 2$ & $\begin{array}{l}\text { Rafter } \\
\text { support posts }\end{array}$ & $\begin{array}{l}\text { Mean height: } 4.47 \mathrm{~m} \text {, mean width } \\
\text { (bottom): } .38 \mathrm{~m} \text {, mean thickness: } 16 \mathrm{~cm}\end{array}$ & \\
\hline Scowlitz & Structure 3 & Postholes & $\begin{array}{l}\text { Most about } 30 \mathrm{~cm} \text { in diameter. Excavated } \\
\text { into sterile gravel. }\end{array}$ & $\begin{array}{l}\text { Lepofsky } \\
\text { et al. } \\
\text { 2000:401 }\end{array}$ \\
\hline $\begin{array}{l}\text { Shingle } \\
\text { Point }\end{array}$ & House $1 \& 2$ & Posts & $\begin{array}{l}\text { Mean length: } 4.47 \mathrm{~m} \text {, mean width at } \\
\text { bottom: } .38 \mathrm{~m} \text { (likely rafter support posts) }\end{array}$ & $\begin{array}{l}\text { Matson } \\
2003\end{array}$ \\
\hline
\end{tabular}

Evidence of structural element repair is common at Ozette, suggesting that maintenance was a continuous activity. Many planks show signs of mending and recycling, implying that house repair was an extremely important household task (Mauger 1978:92-96). Planks with longitudinal cracks were stitched together with cedar withes and entire walls would rot and need to be replaced. Planks were often reused, for example parts of canoes were repurposed in walls. The effort invested in repairing and reusing rather than replacing planks suggests that obtaining new planks was difficult and time consuming. Further evidence of the intensity of building activities is found in the frequency and variety of woodworking tools (such as wedges) noted at Ozette (Gleeson 
1980). This also demonstrates that much time and planning was invested in manufacturing and repairing tools for tasks such as splitting planks.

Archaeological data can aid in reconstructing replacement rates for house elements by providing information regarding weathering of house elements. In their investigation of standing remains of a Nuu-chah-nulth plankhouse built in the midnineteenth century, Smith et al. (2005) note that beams not exposed to the ground were in relatively good condition compared to elements in the soil. Corner posts displayed large amounts of rot, and building elements degraded quicker if they contacted the ground or bore a heavy load. Dendrochronology data from this study where researchers obtained cutting dates from house posts suggest that elements were continually replaced as they became structurally unsound.

Other than wet sites and intact houses, direct archaeological evidence of woodworking and wood harvesting activities related to plankhouses is limited. One culturally modified tree (CMT) that was formed when a plank was split from a tree trunk has been documented in Oregon (Gilsen 2009). Three planks, with widths of about $40 \mathrm{~cm}$ and lengths ranging from about 4-6 m were harvested from this tree. Although this CMT demonstrates that planks were sometimes removed from standing trees rather than split from felled logs, the rarity of this site type tentatively suggests that this method of obtaining planks was not often practiced in the area. This type of culturally modified tree is more prevalent in British Columbia (Stryd 2001).

$\underline{\text { Plankhouses and Western Redcedar }}$ 
As plankhouses were constructed from western redcedar, cedar properties and growth patterns are important to investigating how these dwellings were constructed. Paleoecological data informs the antiquity and development of plankhouses on the Northwest Coast. Metric data are necessary for approximations of the quantity and weight of trees needed to build and repair structures. Properties of cedar wood are requisite for estimating element replacement rates. Cedar distributional data is important to understanding labor costs involved in procuring materials for plankhouses.

Reconstructions of climate on the Northwest Coast during the Early Holocene demonstrate that temperatures were too warm and dry to support cedar (Hebda and Mathewes 1984). By the Mid-Holocene, more moisture and cooler temperatures enabled expansion of cedar and other flora adapted to changing conditions (Whitlock 1992). Regional studies from Oregon and Washington involving palynology, microfossils and genetics demonstrate the dramatic increase of cedar from 6000-5000 B.P. (Barnosky 1985; Hebda 1995:75; Wainman and Mathewes 1987; Worona and Whitlock 1995). A basic understanding of cedar size enables estimates of the amount of trees harvested for house construction and repair. Historical information regarding cedar metrics and distribution in the LCRR is unavailable, however current dynamics of old growth stands are well known. Throughout the Northwest Coast, cedars average almost 60 meters in height and about two meters in diameter at the base, with rapidly tapering trunks (Pojar 2004; Waring and Frankin 1979). Cedar grows most often below 1,000 meters above sea level, where total annual precipitation is less than $300 \mathrm{~cm}$, and mean annual temperature is between 6-8 $\mathrm{C}^{\circ}$ (Lesher and Henderson 2010). Cedar growth is 
sensitive to climate variables, and the most important factors in producing large cedars are warm summers and winters, and high summer precipitation (Harrington and Gould 2010:101). Although cedar was present in the LCRR, trees probably did not reach the maximum sizes as conditions are not as favorable in this area compared to other locations on the coast. However, these measurements provide a baseline for estimating ranges of probable cedar metrics in the vicinity of Meier and Cathlapotle.

Although cedar was present in the LCRR, it was likely not abundant. Cedar is rarely the dominant tree species in Northwest Coast forests, and in fact patterns of distribution were "patchy" throughout the region (Deur and Turner 2005:11). In oldgrowth forests of western Oregon, cedar populations are small compared to other trees (Poage and Tappeiner 2005:335). In a forestry study of land west of the Cascades in Oregon and Washington in 1934, 1.1\% of about 35 million acres were classified as containing predominantly large cedar (Harrington 2003). In the Willamette Valley, 1850s survey assigned only about $14 \%$ of land to vegetation classes that could contain cedar (Christy and Alverson 2011).

A map of historic vegetation illustrates that although some of the upper Wapato Valley was forested, cedar was not a predominant species (Figure 30). Some cedar was likely present in vegetation areas of this map classified as Douglas fir, oak-conifer and oak-Douglas fir. However, trees in Oregon old-growth Douglas fir forests are typically only $1-2 \%$ cedar (Poage and Tappeiner 2005). The immediate areas surrounding Meier and Cathlapotle were likely largely prairie, wetlands and deciduous forests in the past 
(Figures 31 and 32). However, modern cedar stands do exist around Mud Lake, which is located in close proximity to Cathlapotle (Kenneth Ames, personal communication).

In addition to patchy distributions, availability of cedar for building materials was also restricted as quality and size of trees varied considerably. Many cedar fungicides increase with tree age (Russell and Daniels 2010), meaning that larger elements may have been more resistant to decay than smaller elements. Older cedar has a higher content of thujaplicin, a fungitoxin that provides anti-fungal and anti-bacterial protection (Buchanan 1992), and therefore older trees may have been sought for building materials. Cedar suitability for building is variable (Gahr 2006). For example, trees growing in dense stands or close to water are more likely to have knots or low branches (Stewart 1984:24).

Further restricting the availability of cedar was its utilization for a plethora of other technologies. Wood was used for purposes including canoes and boxes, and inner bark was important in a variety of technologies such as clothing and baskets (Stewart 1984). Harvesting inner bark alters the growing patterns of trees, which may render them unsuitable for most construction uses. Turner (2004:84) notes that "tremendous quantities" of cedar inner bark were harvested on the Northwest Coast. One study of cedar culturally modified trees shows that the majority of trees within specific use areas were subject to inner bark harvesting (Lepofsky and Pegg 1996). Paleoecological research also indicates that selective harvesting depleted cedar stands near village sites on the Northwest Coast (LaCourse et al. 2007).

Even considering these issues, cedar was the obvious choice for structures. Cedar is an exemplary building material for house construction: it is easy to work with, splits 


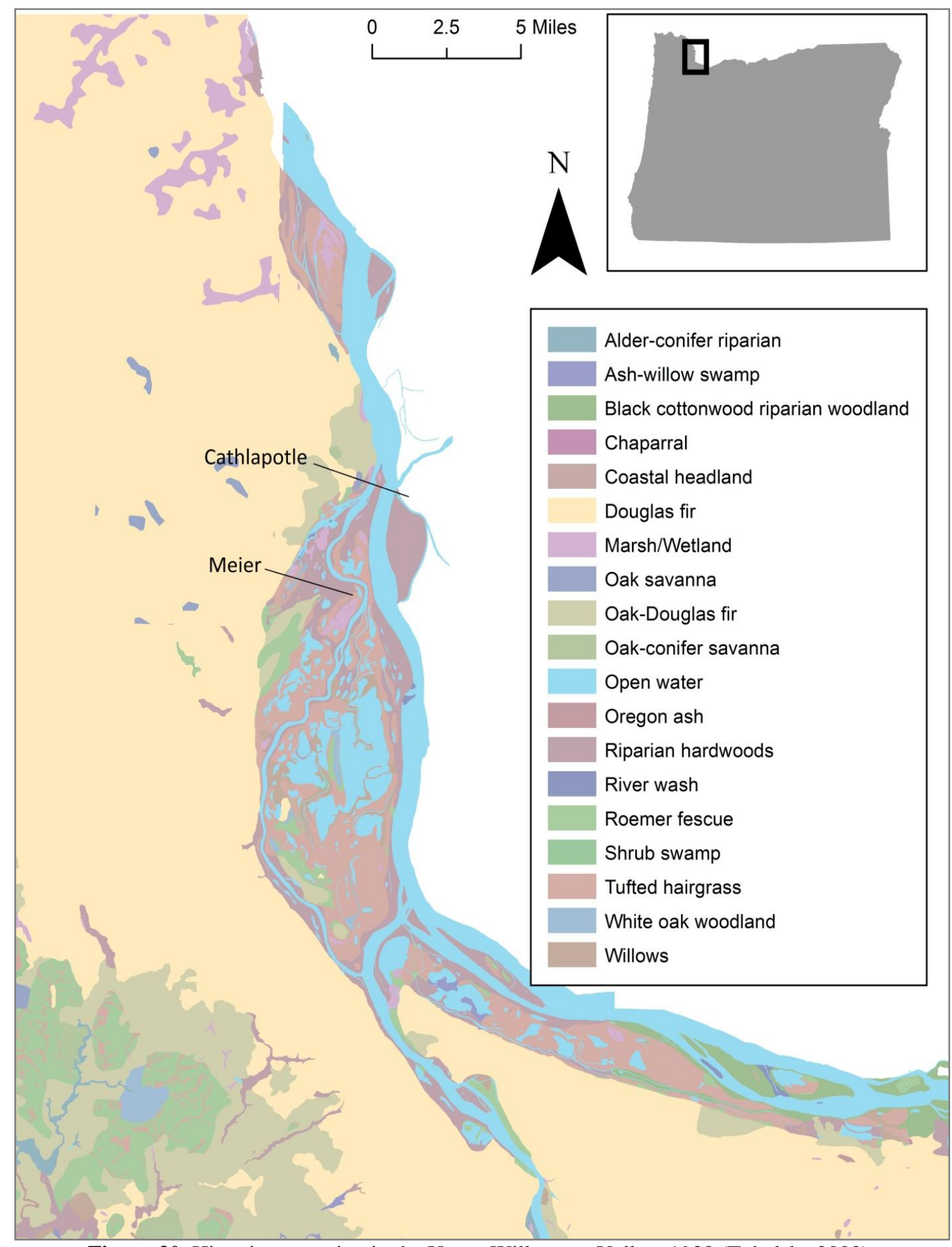

Figure 30. Historic vegetation in the Upper Willamette Valley, 1938 (Tobalske 2002). 


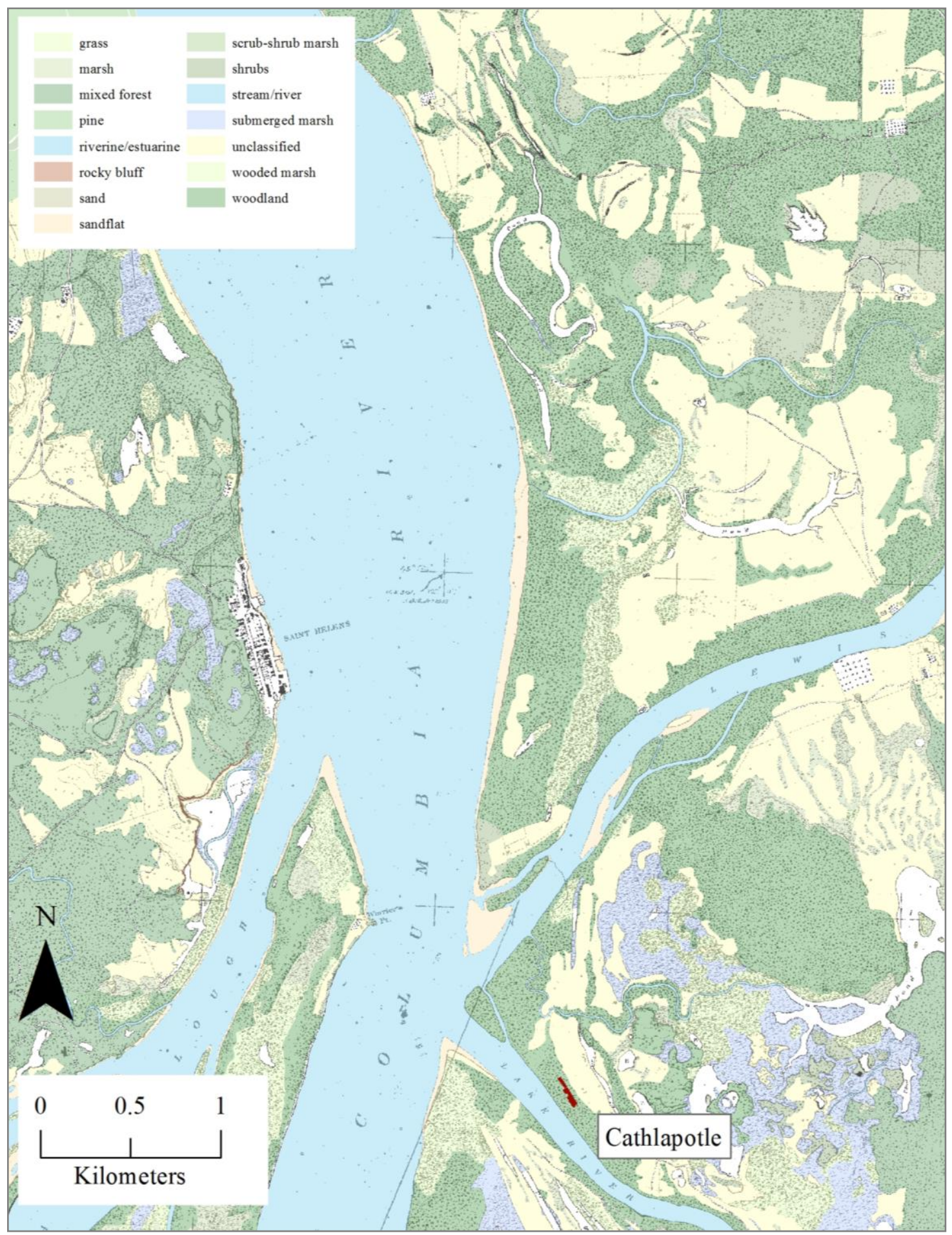

Figure 31. Cathlapotle historical vegetation based on 1850s T-sheets (Burke 2010). 


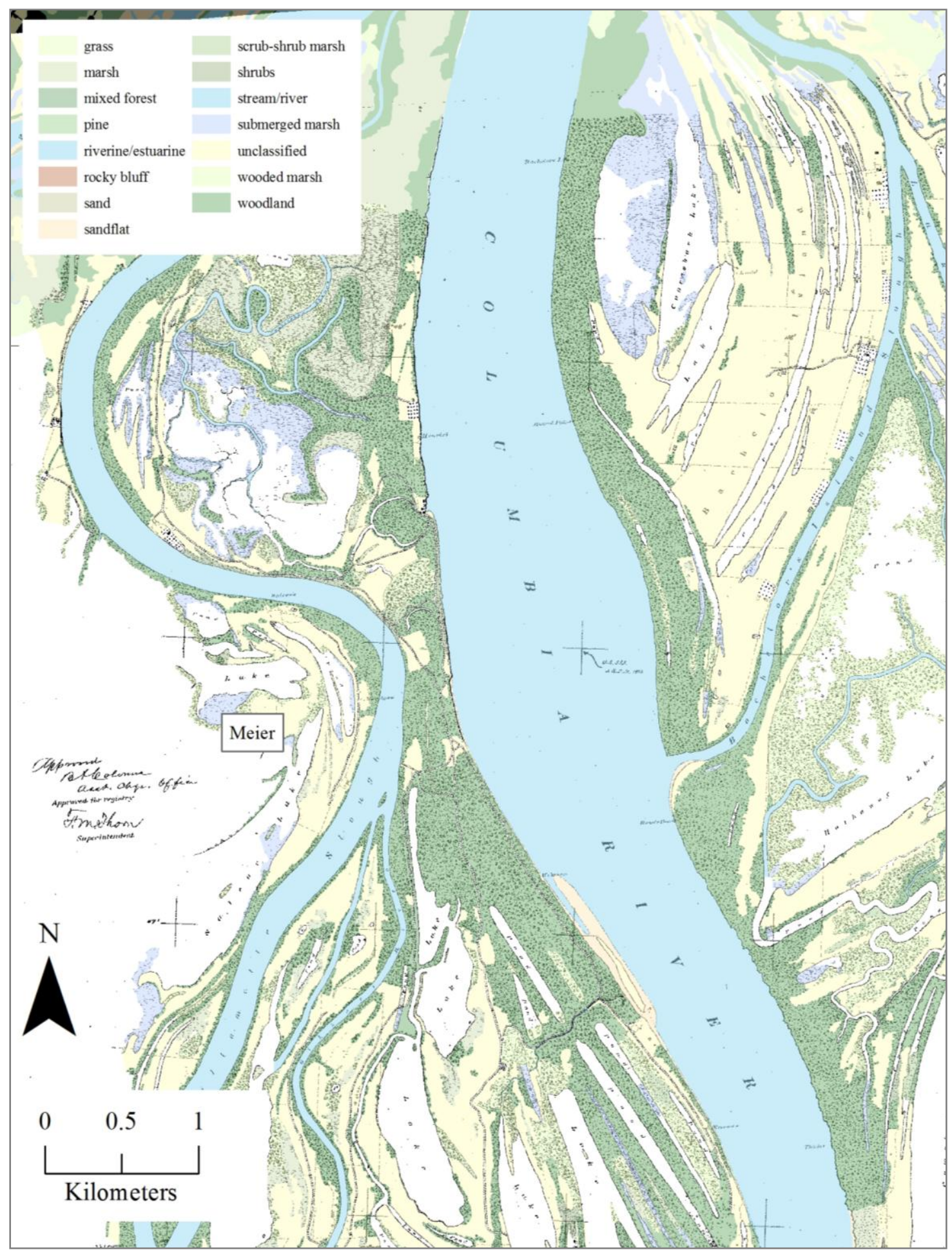

Figure 32. Meier historical vegetation based on 1850s T-sheets (Burke 2010). 
well, keeps its shape when drying, and resists decay and rot (Stewart 1984). Cedar is much less prone to volumetric shrinkage that can warp and split wood than other LCRR trees - its volumetric shrinking percentage of $6.8 \%$ is half of that of most trees on the southern Northwest Coast (Countryman and Kemperman 2000). Low shrinkage rates and low wood density contribute to western redcedar's excellent dimensional stability (Gonzalez 1997:17). Although cedar is resistant to warping and decay, it has comparatively low strength when used as posts and beams and has little shock resistance (Forest Products Laboratory 2010). The use of massive posts and beams in houses would have mitigated this weakness, minimizing the number of times elements would need to be replaced because of the threat of failure.

In summary, it is evident that although using cedar in structures had many benefits, issues did exist. Cedar is prone to decay and distortion from weight stress. Building elements would need to be replaced frequently because of rot. Furthermore, cedar trees were not unlimited resources, conversely, they may have been quite scarce in and around villages, especially considering their high demand for a variety of technologies. 


\section{Chapter 7: Results of Plankhouse Labor Costs Calculations}

\section{Quantifying Materials}

The first step to assessing how much raw material was required for plankhouses is to understand the size of structural elements in these houses. Information from plankmolds and post features can be applied to specific structural components of houses. Four categories of structural elements were investigated: corner posts, eave supports, ridge beam supports, and wall planks (see Figure 7). Features were assigned to structural element based on morphology and house positioning (Figure 33).

Since complete, large features are rare, some incomplete features were 'completed'. At Meier, 53 features fitting into these four structural elements types were either complete $(n=23)$ or able to be completed with a reasonable degree of certainty $(n=30)$. At Cathlapotle, 125 features fitting into these four categories were either complete $(n=52)$ or able to be completed to a reasonable degree of certainty $(n=73)$. Descriptive statistics for features representing structural elements are compiled in Appendix A, while documents used to calculate morphological attributes of structural features are discussed in Chapter 4 and detailed in Appendix B.

Board feet measurements were used to estimate how many trees were used for planks in roofs, siding and floors. First, surface area of roofs, planks and floors was calculated, taking into account differing combinations of wall and roof height, which resulted in a range of possibilities. Table 18 presents ranges of board feet for one course of siding at both Meier and Cathlapotle. Importantly, these figures are underestimates for several reasons. They do not take into account underground portions of wall planks or 
overhanging portions of roof planks. Also, they do not include posts used on top of roofs to secure planking. Finally, these numbers reflect planks that are laid side-by-side, if planks overlapped (as they may have on roofs) more material would have been used.

Table 18. Square Meters of Planked Roof, Siding and Floor, Meier and Cathlapotle.

\begin{tabular}{lcc|cc}
\hline & \multicolumn{2}{c}{ Surface Area $\left(\mathrm{m}^{2}\right)$} & \multicolumn{2}{c}{ Board Feet } \\
& Low Range & High Range & Low Range & High Range \\
\hline Meier with floor & $1,032.8$ & $1,158.2$ & 33,351 & 37,401 \\
Meier without floor & 612.8 & 738.2 & 19,789 & 23,838 \\
Cathlapotle House 4 & 209.8 & 277.0 & 6,775 & 8,946 \\
Cathlapotle House 1B & 148.6 & 198.8 & 4,798 & 6,419 \\
Cathlapotle House 1C & 215.3 & 279.8 & 6,954 & 9,036 \\
Cathlapotle House 1D & 320.2 & 407.4 & 10,339 & 13,155 \\
Cathlapotle House 1 Total* & $1,098.0$ & $1,389.3$ & 38,699 & 44,867 \\
\hline
\end{tabular}

*Includes six short axis sides representing compartment dividers.

Structural element metrics and element counts were used to determine the amount of material and trees used for posts and beams (see Appendix B). Element metrics rather than board feet were used for this calculation, as board feet calculations eliminate curved portions utilized in post and beam elements. Meters of circular wood needed for posts and beams was translated into trees required. To calculate trees needed for initial construction meters of posts and beams were combined with board feet (Table 19).

Table 19. Trees Represented in Initial Construction of Houses, Meier and Cathlapotle.

\begin{tabular}{lccccc}
\hline & \multicolumn{2}{c}{ Trees Represented in } & \multicolumn{2}{c}{ Trees Represented in } \\
& $\begin{array}{c}\text { Siding, Roofing and Flooring } \\
\text { Low Range* }\end{array}$ & High Range* & Low Range** & Heams \\
& 29 & 33 & 22 & 30 & $51-63$ \\
\hline Meier with floor & 17 & 21 & 22 & 30 & $39-51$ \\
Meier without floor & 17 & 8 & 10 & 13 & $16-21$ \\
Cathlapotle House 4 & 6 & 39 & 47 & 63 & $78-102$ \\
Cathlapotle House 1 & 31 & & &
\end{tabular}

*Derived from board feet. **Derived from meters of circular wood calculations.

\section{$\underline{\text { Plankhouse Construction Production Sequence }}$}

A production sequence allows delineation of tasks associated with plankhouse construction and maintenance. The following discussion is heavily based on material drawn from background research presented in Chapter 6. Importantly, this overview 


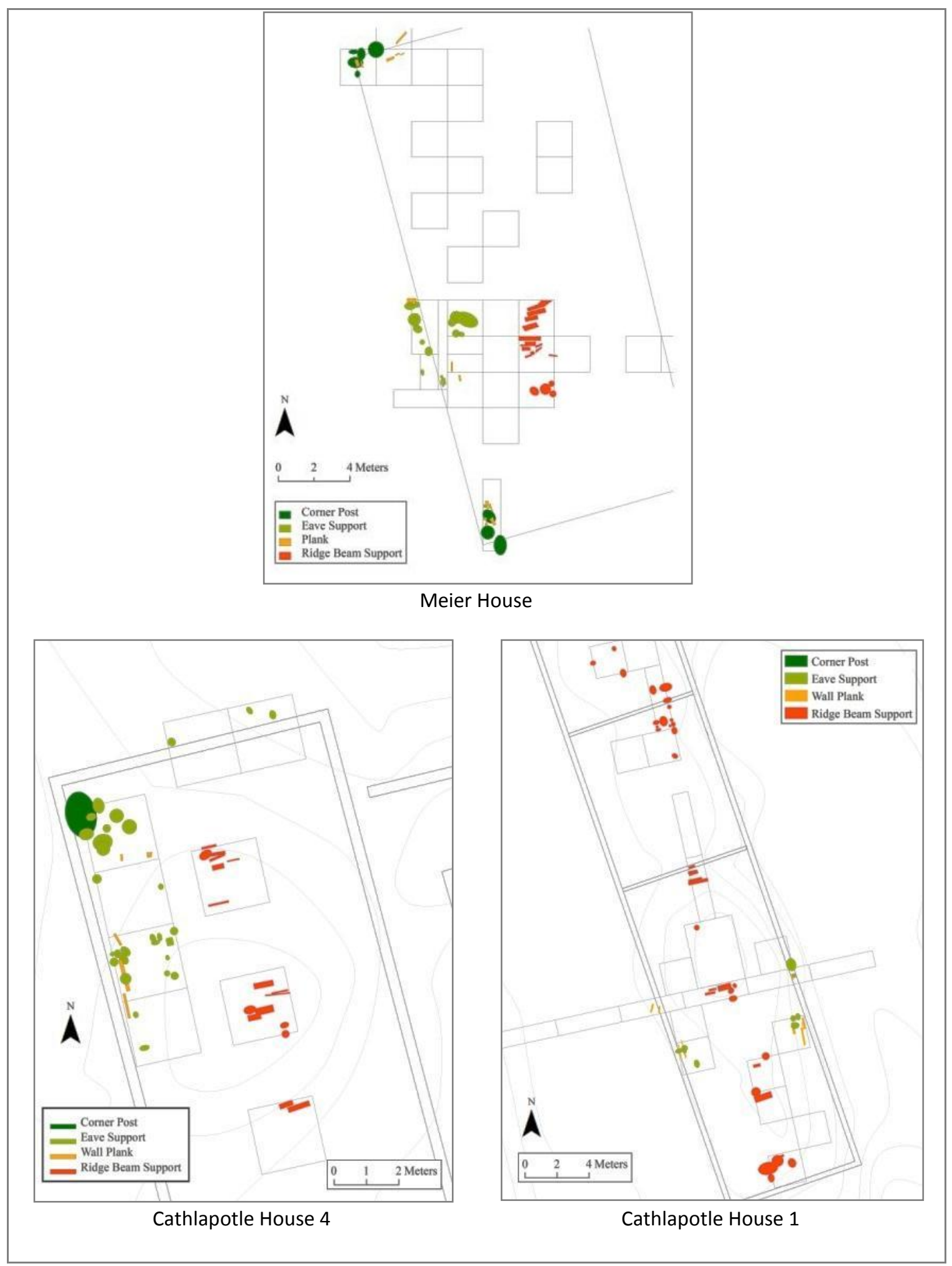

Figure 33. Structural features at Meier and Cathlapotle. 
neglects many significant expenditures of labor, time and resources. These included preconstruction planning, ceremonies and prayers associated with tree felling and construction, as well as various costs of recruiting, organizing and deploying workers. Ethnographic and historical accounts demonstrate that these activities required much labor, time and other resources (Gahr 2006). Additionally, enormous quantities of tools would be needed for harvest, transportion and construction. These would include woodworking tools such as wedges, chisels, mauls, adzes, as well as scoopers for removing soil and baskets for carrying material. Tools would require both manufacture and repair. Other materials would include poles used for skidding, props, bracing and scaffolding. Also, strong rope would need to be manufactured to pull heavy logs and to guide posts as they were raised. Therefore, although the following discussion of materials and construction attempts to be as inclusive as possible, it must be seen only as one part of a larger process.

\section{Procuring Building Materials}

The first step in obtaining building material was to locate and select cedar trees. In addition to the sheer quantity of trees required for initial construction, cedars would be selected for certain characteristics. Different sized trees would need to be located and assessed for quality. Finding suitable trees may have been time consuming because of cedar distribution and growth characteristics. It is difficult to quantify the time and effort that would be spent searching for and selecting the numerous trees needed for posts, beams and planking. Adding to this situation is lack of specific information regarding 
population dynamics of cedar stands in the vicinity of Meier and Cathlapotle.

Nevertheless, it is important not to disregard effort involved in finding and selecting trees.

Once suitable cedars were located, the next step was felling the trees. The work of cutting down the tree was not the sole aspect of tree felling - it was also important to guide the fall of the cedar so that it would not hit other trees or be damaged when hitting the ground. Rough estimates of time spent felling trees were calculated based on the experimental archaeology studies discussed in Chapter 4 with an eight hour work day. Based on this information, group time spent felling trees for initial construction at Meier was around 19-30 days, at Cathlapotle House 1 it was 24-49 days, and at Cathlapotle House 4 it was 5-10 days (Table 20). These figures do not account for interior furnishings such as benches.

Table 20. Hours Required to Fell Trees, Meier and Cathlapotle.

\begin{tabular}{|c|c|c|c|c|c|c|c|}
\hline & \multicolumn{4}{|c|}{ Group Time } & \multicolumn{3}{|c|}{ Person Time } \\
\hline & $\begin{array}{c}\text { Posts and } \\
\text { Beams } \\
\text { (Hours) }\end{array}$ & $\begin{array}{l}\text { Planks } \\
\text { (Hours) }\end{array}$ & $\begin{array}{c}\text { Total } \\
\text { (Hours) }\end{array}$ & Davs & $\begin{array}{c}\text { Minimum } \\
\text { Hours }^{1}\end{array}$ & $\underset{\text { Hours }^{2}}{\text { Maximum }}$ & $\begin{array}{c}\text { Person } \\
\text { Days }\end{array}$ \\
\hline Meier with floor & $19.5-95$ & $130.5-149$ & $150-244$ & 19-30 & $300-487$ & $1500-2435$ & $38-304$ \\
\hline Meier without floor & $19.5-95$ & $76.5-94.5$ & $96-189.5$ & $12-24$ & 192-379 & $960-1895$ & $24-237$ \\
\hline Cathlapotle House 4 & $12-42.5$ & $27-36$ & $39-83$ & $5-10$ & $78-166$ & $390-830$ & $10-104$ \\
\hline Cathlapotle House 1 & $52-215.5$ & $140-176$ & $192-391$ & $24-49$ & $382-782$ & $1910-3910$ & $48-489$ \\
\hline
\end{tabular}

After felling a tree, the next step was removing the tree top, limbs and bark. The tree then would be hauled from the felling location to a watercourse in order to float logs to the house site. Hauling was accomplished by many people working together to push, lift, pull and haul the log across skidding. This major undertaking required varying numbers of people and time depending on the size of the log, the terrain, and the distance from the felling spot to the water. Logs were extremely heavy and moving them over 
dense forest and uneven topography would have been a monumental effort. Although precise calculations of time and manpower needed to move logs are not feasible without information regarding terrain and cedar distribution, estimations of weight of the logs represent many tons of material and hint at the massive effort entailed in these efforts (Table 21).

Table 21. Weight of Wood Material Needed for Initial Construction, Meier and Cathlapotle.

\begin{tabular}{|c|c|c|c|c|c|}
\hline & \multicolumn{2}{|c|}{$\begin{array}{l}\text { Planks for Siding } \\
\text { (metric tons) }\end{array}$} & \multicolumn{2}{|c|}{$\begin{array}{l}\text { Posts and Beams } \\
\text { (metric tons) }\end{array}$} & \multirow{2}{*}{$\begin{array}{c}\text { Total } \\
\text { (metric tons) }\end{array}$} \\
\hline & Low Range & High Range & Low Range & High Range & \\
\hline Meier with floor & 47.03 & 52.73 & 5.54 & 31.32 & $52.57-84.05$ \\
\hline Meier without floor & 27.9 & 33.61 & 5.54 & 31.32 & $33.44-64.93$ \\
\hline Cathlapotle House 4 & 9.55 & 12.61 & 3.37 & 15.88 & $12.92-28.49$ \\
\hline Cathlapotle House 1 & 50.01 & 63.26 & 11.47 & 71.94 & $64.48-135.20$ \\
\hline
\end{tabular}

Koppert (1930) indicates that moving one large log from the felling site to the water in one day took 60-200 people. This would indicate that an astonishing amount of time was devoted to hauling logs needed for initial construction: 3,060-12,600 person days at Meier, 930-4,200 at Cathlapotle House 4 and 4,680-20,400 at Cathlapotle House 1. However, because only one historical source provided data regarding moving logs, I decided these numbers were too speculative for inclusion in final labor calculations. However, even if partially accurate, they demonstrate that transporting logs was a major task associated with house construction.

After a log was hauled to the water, log drivers guided the tree down the watercourse to the building site. Once the tree arrived at the village's beach, it would again be a massive task to drag the log up to the area of house construction. This would likely be accomplished by hundreds of workers pulling the log with strong rope. Preparing for Building 
Both the construction site and materials needed to be prepared for building. One essential task was splitting planks (again, I assume most planks were split from logs rather than pried from trees). Using a default plank width of $40 \mathrm{~cm}$, I calculated the number of planks needed for house roofs, walls and floors (Table 22). Length of these planks varied according to the pitch of the roof and height of the walls. This number reflects one course of non-overlapping planks. Although these numbers are rough estimates, it is evident that a great deal of time would be spent splitting planks. Post, beams and many planks were likely adzed. Mauger (1978) reports that half of all planks at Ozette were adzed, including all roof and bench planks. Considering the large number of planks, posts and beams needed for construction, this would represent a considerable output of time and labor. Roof planks may have been specially grooved to control rain runoff, which would have entailed additional effort.

Table 22. Number of Planks Needed for House Sheathing, Meier and Cathlapotle.

\begin{tabular}{lccccccc}
\hline & $\begin{array}{c}\text { Meier } \\
\text { with } \\
\text { Floor }\end{array}$ & $\begin{array}{c}\text { Meier } \\
\text { without } \\
\text { Floor }\end{array}$ & $\begin{array}{c}\text { Cathlapotle } \\
\text { House 4 }\end{array}$ & $\begin{array}{c}\text { Cathlapotle } \\
\text { House 1B }\end{array}$ & $\begin{array}{c}\text { Cathlapotle } \\
\text { House 1C }\end{array}$ & $\begin{array}{c}\text { Cathlapotle } \\
\text { House 1D }\end{array}$ & $\begin{array}{c}\text { Cathlapotle } \\
\text { House 1 } \\
\text { Total }\end{array}$ \\
\hline Wall* & 220 & 220 & 107 & 83 & 107 & 144 & 379 \\
Roof & 150 & 150 & 66 & 33 & 57 & - & 34 \\
Floor** & 30 & - & - & - & 164 & 238 & - \\
Total & 400 & 370 & 173 & 116 & & \\
\hline *Wall planks were likely shorter than other planks and therefore multiple planks could have been cut \\
from one long plank. **Using a default plank length of 7 m.
\end{tabular}

Prior to construction, the house site was cleared of vegetation and cultural debris. A great deal of earth moving occurred as the plankhouse itself, interior cellars, wall trenches, and postholes were all excavated. Volume of soil moved and person days required to do so were calculated using morphological information from the two sites as well as data from experimental archaeology (see Chapter 4). The precise depths to which the Meier and Cathlapotle houses were originally excavated are difficult to discern 
because of the complex stratification of the sites (Hamilton 1993), so a low estimate of 0.3 meter to a high estimate of 2 meters was used (based on Hajda 1994:179). Although estimates encompass wide ranges, they demonstrate that a great deal of labor was needed to excavate the underground portion of plankhouses, pits and corner post holes (Table 23). At Meier approximately 101-375 person days were needed to excavate soil, at Cathlapotle House 4, 34-104 days, and at Cathlapotle House 1, 116-546 days.

Table 23. Plankhouse Excavated Depth and Estimated Person Days to Excavate, Meier and Cathlapotle.

\begin{tabular}{|c|c|c|c|c|c|c|c|c|c|}
\hline & \multicolumn{2}{|c|}{ Wall Trenches } & \multicolumn{3}{|c|}{ House Depressions } & \multicolumn{2}{|c|}{ Corner Postholes } & \multicolumn{2}{|c|}{ Pits and Cellars } \\
\hline & $\begin{array}{c}\text { Volume } \\
\left(\mathrm{m}^{3}\right)\end{array}$ & $\begin{array}{c}\text { Person } \\
\text { Days }\end{array}$ & $\begin{array}{c}\text { House } \\
\text { Area }\left(\mathrm{m}^{2}\right)\end{array}$ & $\begin{array}{c}\text { Volume } \\
\left(\mathrm{m}^{3}\right)\end{array}$ & $\begin{array}{c}\text { Person } \\
\text { Days }\end{array}$ & $\begin{array}{c}\text { Volume } \\
\left(\mathrm{m}^{3}\right)\end{array}$ & $\begin{array}{c}\text { Person } \\
\text { Days }\end{array}$ & $\begin{array}{c}\text { Volume } \\
\left(\mathrm{m}^{3}\right)^{*}\end{array}$ & $\begin{array}{c}\text { Person } \\
\text { Days }\end{array}$ \\
\hline Meier & 5.7 & 2 & 420 & $\begin{array}{l}126.0- \\
840.0\end{array}$ & $49-323$ & $0.7-2.6$ & 1 & 127 & 49 \\
\hline $\begin{array}{l}\text { Cathlapotle } \\
\text { House } 4\end{array}$ & 2.6 & 1 & 132 & $\begin{array}{l}39.6- \\
264.0\end{array}$ & $15-102$ & $0.7-2.6$ & 1 & 52 & 20 \\
\hline $\begin{array}{l}\text { Cathlapotle } \\
\text { House } 1\end{array}$ & 10.1 & 4 & 658 & $\begin{array}{l}197.4- \\
1316.0\end{array}$ & $76-506$ & $0.7-2.6$ & 1 & 92 & 35 \\
\hline
\end{tabular}

* Based on Ames et al. (2008:6).

Other tasks needed to be accomplished prior to building. Rocks were located and transported to the building site for packing postholes to reduce decomposition. While some rocks may have been small, a few massive boulders approaching one meter in diameter were noted at each site, which would have entailed great effort to move. A variety of tools were made to be used in transporting, splitting and dressing wood, including mauls, wedges, adzes, scaffolding, ladders, and ropes.

\section{Construction}

Understandings of house raising techniques are predominantly based on accounts from the northern and central Northwest Coast. Still, this information provides important clues to how inhabitants of Meier and Cathlapotle may have accomplished the substantial task of house construction. Raising the massive corner posts, eave supports and ridge 
supports entailed the efforts of a large amount of people. Wall planks were fitted in trenches and fastened against eave beams. Roof planks, which stretched between the eave post and ridge post, were lifted and secured. Smaller poles were attached to the roof perpendicularly to the roof planks. A variety of people contributed to labor other than those directly involved in house raising. Specialists directed and coordinated these operations and were in charge of ensuring that house parts were joined and stable. Prominent people conducted ceremonies. Other people prepared food for the hundreds (or possibly thousands!) of workers, and possibly tended to injuries incurred during building.

Gahr (2006) uses several historical accounts of house construction to calculate the number of people needed to erect one dwelling. She estimates that one person is needed for every $0.19-0.33 \mathrm{~m}^{2}$ of house area. By applying these figures to houses with population estimates, Gahr concludes that the number of people required to construct a plankhouse would be $20-48$ times the dwelling's population. These numbers seem reasonable, especially when considering how much manpower it would take to move and hoist the giant posts and beams. Table 24 outlines the number of people that would be needed to build houses at Meier and Cathlapotle based on Gahr's figures.

Table 24. Labor Estimates of House Raising, Meier and Cathlapotle.

\begin{tabular}{lccc}
\hline & Floor Area $\left(\mathrm{m}^{2}\right)$ & $\begin{array}{c}\text { Low Labor Estimate } \\
\text { (Number of People) }\end{array}$ & $\begin{array}{c}\text { High Labor Estimate } \\
\text { (Number of People) }\end{array}$ \\
\hline Meier* & 420 & 1,273 & 2,211 \\
Cathlapotle House 1 & 658 & 1,994 & 3,463 \\
Cathlapotle House 4 & 132 & 400 & 695 \\
\hline
\end{tabular}

*Numbers differ slightly from Gahr's calculations because of different house metrics employed.

In addition to the tasks outlined in the above sections, additional work was required that is difficult to quantify. Much work was devoted to benches and interior furnishings. Wood for small posts and planks would need to be harvested, transported 
and prepared, and sleeping platforms were built around the entire interior. These benches were around 2 m wide (Smith 2004:33) and may have included storage features or decoration. Special attention was likely paid to interior elements at the high status end of the house. Other tasks associated with building a plankhouse are difficult to quantify, but entailed a large amount of labor. Hearths would have needed to be excavated and sided with wood. Many pits would have been lined with planks or clay. Cathlapotle house floors may have been capped with a thin layer of clay or otherwise prepared. Some support posts may have received special decoration.

A summary of person days involved in initial construction of plankhouses is difficult. I was unable to quantify many activities necessary to build these houses. Table 25 reviews the major tasks associated with initial construction, listing maximum and minimum person days when this information is accessible. Although this presentation is incomplete and rife with estimations, it is clear from these data that a massive investment of labor was required to obtain materials for and build houses. Importantly, while some work may have occurred on the same day with many people (see Gahr 2006), other tasks may have included few people over a long period of time.

Table 25. Person Days Associated with House Construction Tasks.

\begin{tabular}{llccc}
\hline & & & Cathlapotle & Cathlapotle \\
Production Step & Specific Task & Meier & House 4 & House 1 \\
\hline Planning & Plan architecture and labor & Unknown & Unknown & Unknown \\
& Prepare tools & Unknown & Unknown & Unknown \\
\hline Procure materials & Locate and select trees & Unknown & Unknown & Unknown \\
& Fell trees & $38-304$ & $10-104$ & $48-489$ \\
& Transport logs & Unknown & Unknown & Unknown \\
\hline Prepare materials & Split and adze wood & Unknown & Unknown & Unknown \\
& Excavate soil & $101-375$ & $37-124$ & $116-546$ \\
\hline Construction & Frame and sheath house & $1,273-2,211$ & $324-563$ & $1,994-3,463$ \\
& Build furnishings & Unknown & Unknown & Unknown \\
& Feed and organize laborers & Unknown & Unknown & Unknown \\
\hline Total excluding unknown labor estimates & $1,412-2,890$ & $371-791$ & $2,158-4,498$ \\
\hline
\end{tabular}




\section{Quantifying Maintenance}

Work and materials required for plankhouses did not stop at the completion of construction. Conversely, a large amount of wood and labor was used in maintenance activities throughout the uselife of the plankhouse. At Meier and Cathlapotle houses stood for hundreds of years, representing continual inputs of both labor and building materials. The following section attempts to quantify the amount of labor and materials used in the approximately 400 years the houses at Meier and Cathlapotle were inhabited.

Gahr (2006:73) considers many aspects of plankhouse repair in her analysis of the plankhouse 'life cycle', and stresses an "enduring commitment of labor and materials" would have been required for plankhouse upkeep. She outlines the stresses placed on wood elements, including load, creep, high winds, earthquakes, hydraulic pressure, fire, and biological decay organisms. Ames et al. $(1992,1996)$ use excavation data to estimate that each house element, depending on its size, would need to be replaced at a minimum of 5 times over the house's 400 year uselife, and probably closer to 20 times.

Further precision of these replacement estimates was achieved by applying information from forestry studies (Chapter 6) to data from features at Meier and Cathlapotle to estimate replacement rates. Bearing heavy loads and direct contact with the soil would cause elements to deteriorate more quickly, so wall and floor planks would have a heightened risk of rot. Roof planks would have also been at high risk of decay because of exposure to moisture. Information regarding cedar decay rates presented in Chapter 6 was used to approximate plank replacement rates, allowing assessment of sheathing needed over the houses' 400 year existence (Table 26). 
Table 26. Total Planking Needs Over House Lifespan, Meier and Cathlapotle.

\begin{tabular}{|c|c|c|}
\hline & \multicolumn{2}{|c|}{ Board Feet (Walls, Roof and Floor) } \\
\hline & Low Range & High Range \\
\hline Meier with floor & $667,023.6$ & $748,011.8$ \\
\hline Meier without floor & $395,770.8$ & 476,759 \\
\hline Cathlapotle House 4 & $135,497.2$ & $178,923.6$ \\
\hline Cathlapotle House 1 & $773,974.6$ & $897,330.0$ \\
\hline
\end{tabular}

I also estimate material that would be needed for post replacement, although rates of post replacement were difficult to determine. It is likely that deteriorating posts would be monitored and quickly replaced, as failure in posts and beams (unlike failure in wall planks) could be catastrophic. Calculating the approximate the number of trees used over each house's 400 year lifespan for repairs yielded an astronomical number of trees. Estimates of trees required for repairs of planks, posts and beams ranged from hundreds of trees for Cathlapotle House 4 to a number approaching 2,000 trees for Cathlapotle House 1 (Table 27).

Table 27. Numbers of Trees Needed for Replacement of Planks and Posts over 400 Year House Lifespan.

\begin{tabular}{|c|c|c|c|c|c|}
\hline & \multicolumn{2}{|c|}{$\begin{array}{l}\text { Trees Represented Siding, } \\
\text { Roofing and Flooring }\end{array}$} & \multicolumn{2}{|c|}{$\begin{array}{l}\text { Trees Represented in Posts } \\
\text { and Beams }\end{array}$} & \multirow[b]{3}{*}{ Total } \\
\hline & Low & High & Low & High & \\
\hline & Range* & Range* & Range** & Range** & \\
\hline Meier with floor & 580 & 650 & 134 & 610 & $714-1,260$ \\
\hline Meier without floor & 344 & 415 & 134 & 610 & $478-1,025$ \\
\hline Cathlapotle House 4 & 118 & 156 & 40 & 246 & $158-402$ \\
\hline Cathlapotle House 1 Total & 673 & 780 & 229 & 1229 & $902-2,009$ \\
\hline
\end{tabular}

*Tree estimates derived from board feet $(1 \mathrm{~m}$ diameter $\operatorname{logs})$. **Tree estimates derived from meters of logs.

In addition to locating, felling and transporting trees for new posts and planks, the process of replacing these elements would have entailed considerable effort and skill. Reynolds (1995) writes about the experience of building and repairing a roundhouse, emphasizing that removing a rotting post from a standing structure is an extremely 
difficult task. The mechanics of replacing a corner post or ridge beam in an inhabited plankhouse would have been extremely challenging. Given that larger posts and beams were likely replaced infrequently, these events may have occurred only about once a generation. Thus, people with knowledge of the mechanics of this operation - building specialists - would have been relatively rare.

It is important to note that in addition to repairs associated with architecture, a number of other activities were necessary for upkeep. Houses at both Meier and Cathlapotle included massive pit complexes, which were constantly re-dug. Hearths were continually maintained and cleaned (see Gardner-O’Kearny 2010). Other ongoing house activities would include sweeping and refuse disposal. Taken together, obtaining and preparing raw materials, repairing wooden elements, and sundry house upkeep tasks would have required an enormous expenditure and variety of different types of labor. 


\section{Chapter 8: Discussion}

\section{$\underline{\text { Research Questions }}$}

GIS and statistical analyses of architectural features at Meier and Cathlapotle predominantly support previously proposed models based on field observations. Results inform understandings of house spatial organization, differences and similarities between houses in the LCRR, and structural stability.

\section{Spatial Organization of Houses}

Results highlight differences between spatial organization at the three study houses. Interior spatial divisions - likely according to rank - were conspicuous and permanent at Cathlapotle House 1. The presence of ridges dissecting other house depressions at Cathlapotle suggest that at least three other houses (Houses 2, 3 and 6) were similarly divided. At Meier and Cathlapotle House 4, compartments within houses were either absent or more ephemeral. This indicates that at these two houses, delineation of house interior by status was not as important as it was at Cathlapotle House 1.

Space outside of houses was organized differently at the two sites. There is more evidence of outside structures at Cathlapotle than at Meier. Notably, two of the most substantial exterior constructions at Cathlapotle were noted between the front of House 1 and the nearby river. There are several possible reasons for the difference in exterior structures between the two sites. First, production activities may have differed between the villages. Meier occupants may have produced fewer goods that necessitated outdoor production, and instead processed goods either from afar or inside the house. Second, this difference may reflect aspects of living in a multi-house village rather than a single-house 
village. Cathlapotle residents may have engaged in production activities outside of the house to facilitate conversation or exhibit their house's products to neighbors. Third, Cathlapotle villagers may have worked outside in order to display their house's specialties to potential traders passing on the river. Fourth, the Cathlapotle house interior may have been more crowded, requiring outdoor production. Perhaps Cathlapotle experienced a large influx of people during winter months, such seasonal variation in settlement in the LCRR is posited by Boyd and Hajda (1989).

In general, data from structural features confirm prior models of interior facilities. Architectural features often differed in size and class distribution between facilities. For example, hearths contained more small posts (or pegs) than other facilities, indicating production areas. This evidence strengthens the argument that houses at Meier and Cathlapotle were divided into zones with respect to both structural elements and activities.

\section{Comparison of House Construction in the LCRR}

This project allows comparison between plankhouse architecture at Meier and Cathlapotle. However, it is important to stress that results were constrained by the relatively small sample size of complete features. Comparison of house framing elements suggests that Cathlapotle residents used larger planks than at Meier for some aspects of construction, such as eave supports and wall sheathing. Meier residents may have used more very large posts in house walls. Furthermore, planks were used more often across all facilities at Meier compared with Cathlapotle. Few statistically significant differences in structural elements were noted between the two Cathlapotle houses, although occupants of House 1 may have used more small planks (compared to small posts) than 
those of House 4. The larger number of small plankmolds in House 1 may be related to pit linings or interior furnishings such as drying racks.

Overall, this evidence suggests that dwellings at the sites were built using similar construction techniques, despite differences in house size. However, variation in construction choices (such as preference for planks or element size) may have existed between Meier and Cathlapotle. These differences may have arisen from factors related to corporate group size, tradition, varying access to materials, or for aesthetic reasons. Regardless, small differences in houses highlight the unique group identity of the households.

\section{Structural Continuity}

Stability of plankhouse appearance underscores the connection between continuity in household groups and their dwellings in the LCRR. Generally, fine-scale maps indicate that structural elements retained similar vertical and horizontal positioning through time in the houses. Conservation of element placement was especially strong in central house areas. However, maps pinpointed several spots in all three houses where element elevation changed in house walls. The most variation in vertical positioning of elements seems to have occurred in Cathlapotle House 4, and it is also possible that the house underwent a significant change in length during its lifespan. The Meier House also may have been substantially altered, as evidenced from wall trench placement indicating that the house was shortened by at least one meter. Overall, however, evidence of changing house attributes is the exception rather than the norm. 
Continuity in house appearance was also studied by examining plankmold orientation. It is important to note that results were affected by small sample size and possible outliers, which may have inhibited detection of trends. Using maps and several statistical tests, I was unable to identify clear instances of shifting house orientations over time. Meier may have experienced a shift in orientation in the middle of its uselife. This result is tentative, but interesting in light of prior evidence suggesting a change in Meier house orientation by 10-15 degrees (Ames et al. 1992) and plankmolds noted under hearths that indicate changing use of interior space (Gardner-O'Kearny 2010). Despite some minor modifications, houses were overall remarkably stable in structural appearance over the passing centuries and changing of many generations.

Since household groups were inextricably linked to plankhouses, change in the physical house structure would indicate possible shifts in social organization. Results of this project strengthen previous assessments (Ames et al. 1992; Smith 2004:66) that households maintained remarkable continuity over hundreds of years. Importantly, this continuity does not reflect stasis in the community as a whole. Rather, household stability persisted in light of climatic and environmental shifts (Calkin et. al 2001; Grove 1988:231-239) as well as demographic, economic and technological changes in the protohistoric period (Boyd 1999; Lightfoot 2006). Remarkable stability in the midst of other changes demonstrates that much value was afforded to and effort was directed towards sustaining household continuity. 


\section{$\underline{\text { Broader Implications }}$}

Information regarding plankhouse construction and maintenance history, as well as materials and labor requirements, can be used to study aspects of economic organization and sociopolitical aspects of Northwest Coast groups. Results of this study also enable richer understandings of everyday life for residents of the Meier and Cathlapotle communities.

Everyday Labor

This study identifies specific types of labor that people routinely engaged in on the Northwest Coast. Some plankhouse-related tasks involved short bursts of highly coordinated work, such as house raising, which also required a massive amount of physical strength and cohesion. Many undertakings comprised physical labor (such as moving logs through the woods or digging soil) or repetitive tasks (such as splitting and adzing planks). Most aspects of plankhouse labor involved mechanical ingenuity and understanding of physics principles, which were needed to fell trees, transport logs, and raise heavy posts for house frames. Ecological knowledge and a deep familiarity with the landscape were necessary to locate and select appropriate building materials. Felling required experience and knowledge of how to properly cut trees in order to minimize damage to lumber and avert potentially hazardous accidents.

Although specialists likely possessed specific knowledge, all people involved in plankhouse building tasks made day-to-day decisions and calculations that were predicated on an intricate combination of knowledge and experience. This is seen in tasks that on the surface seem mundane and purely physical, such as moving logs through the 
forest, but were in fact complex activities requiring many facets of knowledge, decision making, and organization. Importantly, these tasks would also require an intimate knowledge of the landscape.

\section{Specialization}

Specialization was integral to the remarkable social complexity of Northwest Coast societies (Ames and Maschner 2000). This study provides continuing evidence for embedded specialists on the Northwest Coast who performed fundamental tasks for household continuity (Ames 1995), and reinforces evidence for specialization by rank at Meier and Cathlapotle (Smith 2006; Sobel 2004). Tasks connected with plankhouse construction involved a rubric of calculations, planning, coordination, and careful organization at each step. Supervisors would need to possess not only technical skills to coordinate movement of heavy (and potentially deadly) large logs, but also the ability to strategically plan and designate tasks to workers. Also required was the ability to make complex calculations regarding raw materials, time and labor.

Varying degrees of organization and direction would be needed for different tasks. Activities such as tree felling, splitting, and adzing hundreds of planks could likely be directed by one person and carried out by a relatively small amount of household members (including slaves), especially over a long period of time. However, other tasks such as moving logs and house raising would have needed skilled supervision over dozens, hundreds, or even thousands of people. Therefore, it is likely that for complex tasks, a system of direction was utilized. 
Specialized knowledge was necessary for initial building activities as well as house raising. A great deal of specific knowledge was needed to plan house layout, locate and select appropriate trees, and direct the multitude of activities associated with preparing for building (laying out wall trenches and cellars, shaping support posts, etc.). Importantly, as house building was not a common occurrence, the person(s) in charge of directing initial construction may not have overseen similar tasks before or again in their lifetime. This highlights cooperation between houses and villages, not just in terms of labor, but also in sharing knowledge, advice and oral traditions. Specific aspects of house building were likely curated and orally passed through generations.

Similar specialization and specific knowledge would be required for maintenance tasks. Results of this project suggest that some repair tasks, such as replacing small posts or roofing, would have occurred fairly regularly (i.e. every 10-20 years). However, larger posts would need to be replaced only every 50-130 years. Since there were few large posts per house, generations could pass between major replacement episodes. Thus, similarly to house construction, knowledge regarding performing these tasks would need to be shared and passed down through generations.

\section{Cedar Management}

Managing cedar resources was an important aspect of building and maintaining plankhouses, as approximately 90 trees were needed in initial construction for Cathlapotle House 1, 20 for Cathlapotle House 4 and 50 for the Meier House (see Table 19). A large settlement such as Cathlapotle would require an enormous amount of trees for continued maintenance. By extrapolating from the House 1 and 4 estimates to the 
other houses in the village using depression size, I roughly calculate that for the entire Cathlapotle village, upkeep of the houses over 400 years would require 3,026-6,908 trees.

It is clear that cedar would need to be carefully managed rather than haphazardly harvested, given the constant need to replace rotting elements, the limited distribution of cedar in the LCRR, and the need to conserve cedar for use in other technologies. Consequently, knowledge of proper tree characteristics for building, ability to locate these trees, and balancing competing demands on this resource are aspects of plankhouse construction that should not be underestimated. Management almost certainly entailed careful consideration of harvesting, and may have involved 'tending' activities evident for other Northwest Coast plant resources (Derr 2012; Deur and Turner 2005). Although we do not know the mechanics of this system, continued use of cedar for both houses and other technology in the same area through hundreds (if not thousands) of years clearly indicates that people practiced sustainable decision-making. If a thoughtful and strategic resource management system was used for cedar, these same practices may have been in effect for other resources.

Selecting and harvesting cedar is an example of an economic activity that occurred away from villages, where much research on Northwest Coast production is focused (Oliver 2007). Archaeological evidence of Indigenous logging and cedar management is scarce on the southern Northwest Coast, with the exception of preserved woodworking tools and the occasional CMT. The large amount of wood used in houses allows an inference to be drawn that both large-scale logging and cedar management occurred. Although we may not be able to detect direct evidence, forests were not the 
closed, foreboding places described by many European explorers (see Deur and Turner 2005), but were in fact cultural landscapes that were frequently traveled through, worked in, and managed by native inhabitants.

The large amount of choice cedar needed for building tasks and the limited distribution of these trees implies that cedar stands may have been owned by households. Ownership of cedar patches accords with Richardson's (1982) suggestion that patchy resources (meaning those that are predictable and relatively abundant but constrained to certain locations) are likely to be owned by kin groups. Ownership of cedar stands by elites has been noted in the ethnographic record on other areas of the Northwest Coast (Turner and Jones 2000).

\section{Expense of Construction}

This project corroborates previous studies which found huge volumes of raw material and labor were required for plankhouse construction (Ames et al. 1992; Gahr 2006). Data from this project also show that a great deal of labor was needed to fell, transport and prepare lumber for both building and repair. The amount of labor entailed in house construction and maintenance activities is staggering. To summarize, Cathlapotle House 1 required a minimum of 2,134-4,058 person days for initial construction, with 363-677 for Cathlapotle House 4, and 1,393-2,616 for Meier. The amount of time spent preparing the house site, as well as selecting, transporting and felling trees for maintenance efforts, would have required that others in the household provide food and other necessities for the workers involved in these tasks. For initial 
construction, workers would have needed to transport around 70-150 tons of wood for Cathlapotle House 1, 15-30 tons for House 4, and 60-90 tons for Meier.

The massive amount of person hours represented in plankhouse tasks, especially for events such as house raising and log transport, would have required time not only from house members, but also an influx of labor from two other sources. First, as in other complex production tasks in the region, a great deal of labor was performed by slaves (Ames 2008). Second, people to aid in large tasks were contracted through social and political ties and obligations. Recruitment of workers would have been a formidable task. The numbers of people involved in house raisings and log transport would have required enlistment of people from other household groups, and almost certainly from neighboring villages. Amassing a large body of labor would have demanded a massive output of wealth and social capital.

\section{Household Continuity}

Houses were an integral aspect of household group identity, a connection that was present through all stages of house building and uselife, from initial planning to continued maintenance. By examining the processes involved in building plankhouses and ensuring their upkeep, it is clear that vast amounts of materials, labor and ingenuity were bound up in these structures. The large amounts of workers needed to transport logs and construct a house frame provided a display of group strength and solidarity that continued to be perceptible throughout the house's uselife. House maintenance was continuous and required large amounts of labor and raw materials. The clear output of 
work entailed in plankhouses is evident not only in retrospect to archaeologists, but also would be apparent to house inhabitants, as it was evident in the physical house structure.

The construction and maintenance of plankhouses is an example of cultural continuity achieved through purposeful actions of household members. House structure and layout was maintained over many generations, not by chance, but by deliberate thought and hard work of household members. Villagers would not only be reminded of group continuity and enormity of labor costs by houses, but also by stumps encountered in the forest that were cut by ancestors.

\section{Future Directions}

In this thesis I use archaeological information on plankhouse building to provide a window into the organization and orchestration of one complex labor task: the construction and upkeep of plankhouses. This knowledge can be applied to other complex labor tasks on the Northwest Coast where archaeological signatures are less visible. Such tasks include cornerstones of Northwest Coast economies such as salmon fishing and processing, berry and other plant harvesting, and protohistoric fur trapping and processing. The organization of plankhouse construction suggests the presence of both specialists and resource patch ownership, and also demonstrates that large amount of labor could be deployed for major production activities.

Further research into both architecture and plankhouse-related labor will increase our understanding of Northwest Coast groups. Several avenues for future study seem particularly promising. Larger sample size of comparable architectural feature datasets would enable fine-grained comparisons of structural elements between different 
geographic areas. Additional experimental archaeological data regarding felling, transporting, splitting, and adzing logs would greatly refine labor calculations. Data on geographically-specific cedar degradation rates for different sized elements would improve estimates of replacement rates. Continued research into historical vegetation would illuminate the availability of cedar near specific villages, and would be an important step in characterizing Indigenous resource management. Finally, conducting interviews with tribal members would illuminate the continuing role of plankhouses and cedar for peoples of the Northwest Coast in the twentieth and twenty-first centuries. 


\section{Chapter 9: Conclusions}

In this study, elements of political economy are used to investigate labor involved in the plankhouses produced by Northwest Coast hunter-gatherers. Political economy is typically associated with studies of capitalist societies and world systems theory (Roseberry 1988). However, in light of increased globalization and homogenization of modern economic systems, archaeologists have an important role to play in this research. In contrast to modern economies, pre-capitalist economies were extremely diverse. Archaeological studies of hunter-gatherer political economies not only illuminate the unique history of individual groups, but also remind us that different economic formations are possible outside of the current capitalist economy (Cobb 1993:46; Earle 2002:8). Plankhouse production increases knowledge of LCRR political economy related to all three aspects of Saitta's (2012) definition of this theory: production, social labor, and "cultural conditions that sustain relationships".

Plankhouse production is a clear example of hunter-gatherers in western North America organizing complicated tasks and strategically managing resources. Labor tasks associated with plankhouses entailed foresight, careful management of resources and labor, mechanical skill, strength and cooperation. In recent decades, researchers across the world have demonstrated that the variety of tasks and decisions hunter-gatherer groups engaged in was far more sophisticated and nuanced than previously assumed (see Ames 2004; Kelly 1995). This project sheds light on a small range of household undertakings at two villages, but in doing so adds to the literature documenting the incredible diversity and ingenuity of cultures in western North America. 
Although this thesis touches on a diverse range of topics, the daily work of household group members is a unifying thread. Through investigating how houses were built and maintained, we see the tasks and decisions that were part of everyday life for LCRR peoples. It is clear that although physical labor was certainly part of working, equally important was communal organization, thoughtful planning and strategic management of resources. In the large amount of labor entailed in maintaining dwelling appearance over time, we see the daily actions of individuals adding up to stability of houses and household groups over many generations.

In accounting for continuity of Nuu-chah-nulth households in the face of massive social and political upheavals in the contact era, Marshall (2000:74) argues that the strong kinship and social ties exhibited by household groups were dependent on material aspects of the culture: the household economy, house members, and the plankhouse dwelling itself. Using archaeological and historical data, she demonstrates that "the corporate identity of a house must be performed into existence by a dwelling's inhabitants through their actions as co-residents". In this thesis, I argue that the household group was, in part, 'performed into existence' through the numerous everyday tasks of building and repairing plankhouses. 


\section{References Cited}

Abrams, Elliot M.

1994 How the Maya Built their World: Energetics and Ancient Architecture. University of Texas Press, Austin.

Ames, Kenneth M.

1995 Chiefly Power and Household Production on the Northwest Coast. In Foundations of Social Inequality, edited by T. Douglas Price and Gary M. Feinman, pp. 155-187. Plenum Press, New York.

1996 Life in the Big House: Household Labor and Dwelling Size on the Northwest Coast. In People Who Live in Big Houses: Archaeological Perspectives on Large Domestic Structures, edited by Gary Coupland and E.B. Banning, pp. 178-200. Prehistory Press, Madison.

2003 The Northwest Coast. Evolutionary Anthropology 12:19-33.

2004 Supposing Hunter-Gatherer Variability. American Antiquity 69(2): 364-374.

2008 Slavery, Household Production, and Demography on the Southern Northwest Coast: Cables, Tacking and Ropewalks. In Invisible Citizens: Captives and Their Consequences, edited by Catherine M. Cameron, pp. 138-158. University of Utah Press, Salt Lake City.

Ames, Kenneth M., Doria F. Raetz, Stephen Hamilton, and Christine McAfee

1992 Household Archaeology of a Southern Northwest Coast Plank House. Journal of Field Archaeology 19(3):275-290.

Ames, Kenneth M., Cameron M. Smith, William Cornett, Steven Hamilton, Elizabeth A. Sobel, J. Wolf and Doria Raetz.

1999 Archaeological Investigations at 45CL1 Cathlapotle (1991-1998), Ridgefield Wildlife Refuge, Clark County, Washington: A Preliminary Report. Cultural Resource Series Number 13. U.S.D.I. Fish and Wildlife Service, Region 1, Portland.

Ames, Kenneth M. and Herbert D.G. Maschner

2000 People of the Northwest Coast: Their Archaeology and Prehistory. Thames and Hudson, New York.

Ames, Kenneth M., Cameron M. Smith, Alexander Bourdeau

2008 Large Domestic Pits on the Northwest Coast of North America. Journal of Field Archaeology 33(1):3-18.

Ames, Kenneth M. and Elizabeth A. Sobel

2009 Finding and Dating Cathlapotle. Archaeology in Washington 15:5-32. 
2013 Houses and Households. In Chinookan Studies, edited by Kenneth M. Ames, Robert Boyd, and Tony Johnson, pp.125-145. University of Washington Press, Seattle.

Arnold, Jeanne E. and Anabel Ford

1980 A Statistical Examination of Settlement Patterns at Tikal, Guatemala. American Antiquity 45(4):713-726.

Baker, Philip

2005 Techniques of Archaeological Excavation. Taylor \& Francis, Oxford.

Barlett, Peggy F.

1989 Dimensions and Dilemmas of Householding. In The Household Economy:

Reconsidering the Domestic Mode of Production, edited by Richard Wilk, pp. 310. Westview Press, Boulder, Colorado.

Barnosky, Cathy

1985 Late Quaternary Vegetation near Battle Ground Lake, Southern Puget Trough, Washington. Geological Society of America Bulletin 96:263-271.

Bawden, Garth

1982 Community Organization Reflected by the Household: A Study of Pre-Columbian Social Dynamics. Journal of Field Archaeology 9:165-181.

Boas, Franz

1916 Tsimshian Mythology. In The Thirty-Fifth Annual Report of the Bureau of American Ethnology. Government Printing Office, Washington D.C.

1921 Ethnology of the Kwakiuth. In The Thirty-First Annual Report of the Bureau of American Ethnology. Government Printing Office, Washington D.C.

Boyd, Robert

1999 The Coming Spirit of Pestilence: Introduced Infectious Diseases and Population Decline Among Northwest Coast Indians. University of Washington Press, Seattle.

2011 Cathalapotle and its Inhabitants, 1792-1860. Cultural Resources Series Number 15. U.S.D.I. Fish and Wildlife Service, Region 1, Portland.

Boyd, Robert and Yvonne Hajda

1989 Seasonal Population Movement along the Lower Columbia River: The Social and Ecological Context. American Ethnologist 14(2):309-326.

Buchanan, Brian

1992 Restoring and Treating Wood Shakes and Shingles. Journal of Light Construction.

Burke, Jennifer L. 
2010 Georeferenced Historical Topographic Survey Maps of the Columbia River Estuary. School of Aquatic and Fishery Sciences, University of Washington, Seattle.

Butler, Stephanie

2007 The Interpretation of Indoor Storage Facilities from Two Plank House Sites in the Greater Lower Columbia River Region. Master's thesis, Department of Anthropology, Portland State University, Portland, Oregon.

Calkin, Parker E., Gregory C. Wiles, and David J. Barclay

2001 Holocene Coastal Glaciation of Alaska. Quaternary Science Reviews 20:449-461.

Cobb, Charles

1993 Archaeological Approaches to the Political Economy of Nonstratified Societies. Archaeological Method and Theory 5:43-100.

Carll, Charles G.

2009 Decay Hazard (Scheffer) Index Values Calculated from 1971-2000 Climate Normal Data. General Technical Report FPL-GTR-179. US Department of Agriculture, Forest Service, Forest Products Laboratory, Madison, WI.

Carmean, Kelli

1991 Architectural Labor Investment and Social Stratification at Sayil, Yucatan, Mexico. Latin American Antiguity 2(2):151-165.

Christy, John A. and Edward R. Alverson

2011 Historical Vegetation of the Willamette Valley, Oregon, circa 1850. Northwest Science 85(2):93-107.

Coupland, Gary

1985 Household Variability and Status Differentiation at Kitselas Canyon. Canadian Journal of Archaeology 9:39-56.

1993 Prehistoric Subsistence and Seasonality at Prince Rupert Harbor: Evidence from the McNichol Creek Site. Canadian Journal of Archaeology 17:59-73.

Coupland, Gary, Terence Clark, and Amanda Palmer

2009 Hierarchy, Communalism, and the Spatial Order of Northwest Coast Plank Houses: A Comparative Study. American Antiquity 74(1):77-106.

Countryman, David and J.A. Kemperman

2000 Forest Reference Handbook. Iowa State University, Ames, Iowa.

Davis, Sara 
2010 Projectile Point Variation at the Meier (35CO5) and Cathlapotle (45CL1)

Archaeological Sites. Master's thesis, Department of Anthropology, Portland State University, Portland.

Derr, Kelly

2012 Intensifying with Fire: Floral Resource Use and Landscape Management by the Precontact Coast Salish of Southwestern British Columbia. PhD dissertation, Department of Anthropology, Washington State University, Pullman.

Deur, Douglas and Nancy J. Turner

2005 Introduction: Reassessing Indigenous Resource Management, Reassessing the History of an Idea. In Keeping it Living: Traditions of Plant Use and Cultivation on the Northwest Coast of North America, edited by Douglas Deur and Nancy J. Turner, pp. 3-34. University of Washington Press, Seattle.

Drennan, Robert D.

2004 Statistics for Archaeologists: A Common Sense Approach. Springer, New York.

Drucker, Philip

1966 Culture Element Distributions. In Indians of the North Pacific Coast, edited by Tom McFeat, pp. 261-266. University of Washington Press, Seattle.

Earle, Timothy

2002 Bronze Age Economics: The Beginnings of Political Economies. Westview Press, Boulder.

Eaton, Diane F. and Sheila Urbanek

1995 Paul Kane's Great Nor-West. University of British Columbia Press, Vancouver.

Ellis, David V.

n.d. Willamette Associates' 1984 Investigations in the Meier Site Locality. On file at the Department of Anthropology, Portland State University.

2006 Of a More Temporary Cast: Household Production at the Broken Tops Site. In Household Archaeology on the Northwest Coast, edited by Elizabeth A. Sobel, D. Ann Trieu Gahr, and Kenneth M. Ames, pp. 120-139. International Monographs in Prehistory, Ann Arbor.

Erasmus, Charles J.

1965 Monument Building: Some Field Experiments. Southwest Journal of Anthropology 21(4):277-301.

Forest Products Laboratory

2010 Wood as an Engineering Material. General Technical Report FPL-GTR-190. US Department of Agriculture Forest Service, Madison, Wisconsin. 
Flaete, Per Otto, Fred G. Evans, and Gry Alfredsen

2009 Natural Durability of Different Wood Species - Results after Five Years of Testing in Ground Contact. In Proceedings of the $5^{\text {th }}$ Meeting of the Nordic-Baltic Network in Wood Material Science and Engineering, edited by A. Bergstedt, pp. 65-70. Forest and Landscape, Copenhagen, Denmark.

Fleisher, J. and A. LaViolette

1999 Elusive Wattle-and-Daub: Finding the Hidden Majority in the Archaeology of the Swahili. AZANIA: Journal of the British Institute in Eastern Africa 34(1):87-108.

Fuld, Kristin

2012 The Technological Role of Bone and Antler Artifacts on the Lower Columbia: A Comparison of Two Contact Period Sites. Master's thesis, Department of Anthropology, Portland State University, Portland.

Gahr, D. Ann Trieu, Elizabeth A. Sobel, and Kenneth M. Ames

2006 Introduction. In Household Archaeology on the Northwest Coast, edited by Elizabeth A. Sobel, D. Ann Trieu Gahr, and Kenneth M. Ames, pp. 1-15. International Monographs in Prehistory, Ann Arbor.

Gahr, D. Ann Trieu

2006 From Architects to Ancestors: The Life Cycle of Plank Houses. In Household Archaeology on the Northwest Coast, edited by Elizabeth A. Sobel, D. Ann Trieu Gahr, and Kenneth M. Ames, pp. 57-79. International Monographs in Prehistory, Ann Arbor.

Gardner-O'Kearney, William

2010 Hearth Variability at Lower Columbia River Villages. Master's thesis, Department of Anthropology, Portland State University, Portland.

Giddens, Anthony

1971 Capitalism and Modern Social Theory: An Analysis of the Writings of Marx, Durkheim and Weber. Cambridge University Press, Cambridge.

Gilsen, Leland

2009 Housing. Electronic document, http://www.oregonarchaeology.com/theory/ housing/summary, accessed March 31, 2013.

Gleeson, Paul F.

1980 Ozette Woodworking Technology. Ph.D. dissertation, Department of Anthropology, Washington State University, Pullman.

Goddard, Pliny E. 
1972 Indians of the Northwest Coast. Cooper Square Publishers, New York.

Gonzalez, Josefina S.

1997 Growth, Properties and Uses of Western Redcedar (Thuja plicata). Forintek Canada, Vancouver.

Grier, Colin

2001 The Social Economy of a Prehistoric Northwest Coast Plankhouse. PhD dissertation, Department of Anthropology, Arizona State University, Tempe.

Grove, Jean M.

1988 The Little Ice Age. Routledge, New York.

Hagstrum, M.

2001 Household Production in Chaco Canyon Society. American Antiquity 66(1):47-55.

Hajda, Yvonne

1994 Notes on Indian Houses of the Wappato Valley. Northwest Anthropological Research Notes 28(2):177-188.

Hally, David J.

2008 King: The Social Archaeology of the Late Mississippian Town in Northwestern Georgia. University of Alabama Press, Tuscaloosa, Alabama.

Hamilton, Steve C.

1993 Preliminary Testing of Cathlapotle. On file, Department of Anthropology, Portland State University, Portland, Oregon.

Harrington, Constance A.

2003 The 1930s Survey of Forest Resources in Washington and Oregon. General Technical Report PNW-GTR-584. U.S. Department of Agriculture, Forest Service, Pacific Northwest Research Station, Portland.

Harrington, Constance A. and Peter J. Gould

2010 Growth of Western Redcedar and Yellow Cedar. In A Tale of Two Cedars:

International Symposium on Western Redcedar and Yellow-Cedar, edited by Constance A. Harrington, pp. 97-102. General Technical Report PNW-GTR-828. U.S. Department of Agriculture, Forest Service, Pacific Northwest Research Station, Portland.

Hayden, Brian, and Aubrey Cannon

1981 The Corporate Group as an Archaeological Unit. Journal of Anthropological Archaeology 1(2):132-158. 
Hayden, Brian

1997 Observations on the Prehistoric Social and Economic Structure of the North American Plateau. World Archaeology 29(2):242-261.

Hebda, Richard J., and Rolf W. Mathewes

1984 Holocene History of Cedar and Native Indian Cultures of the North American Pacific Coast. Science 225 (4663):711-713.

Hebda, Richard J.

1995 British Columbia Vegetation and Climate History with Focus on 6 ka BP. Géographie Physique et Quaternaire 49(1):55-79.

Hendon, Julia A.

1996 Archaeological Approaches to the Organization of Domestic Labor: Household Practice and Domestic Relations. Annual Review of Anthropology 25:45-61.

Highley, T.L.

1995 Comparative Durability of Untreated Wood in Use Above Ground. International Biodeterioration and Biodegradation 35(4):409-419.

Hodges, Charles and Cameron Smith

2002 Responses to Chronic Flooding at Cathlapotle (45CL1): Clark County Washington. Manuscript on file, Portland State University.

Hoffman, Brian W.

1999 Agayadan Village: Household Archaeology on Umimak Island, Alaska. Journal of Field Archaeology 26(2):147-161.

Iverson, Johannes

1956 Forest Clearance in the Stone Age. Scientific American 194(22):36-41.

Jewitt, John Rodgers

1987 The Adventurers and Sufferings of John R. Jewitt: Captive of Maquinna. University of Washington Press, Seattle.

Kelly, Robert

1995 The Foraging Spectrum: Diversity in Hunter-Gatherer Lifeways. Smithsonian Institution Press, Washington DC.

Kent, Susan

1990 A Cross-Cultural Study of Segmentation, Architecture, and the Use of Space. In Domestic Architecture and the Use of Space: An Interdisciplinary Cross-Cultural Study, edited by Susan Kent, pp. 127-152, Cambridge University Press, Cambridge. 
Kolb, Michael J.

1997 Labor Mobilization, Ethnohistory, and the Archaeology of Community in Hawai'i. Journal of Archaeological Method and Theory 4(3/4):265-285.

Koppert, Vincent A.

1930 Contributions to Clayoquot Ethnology. The Catholic University of America, Washington D.C.

Lacourse, Terri, Rolf W. Mathewes and Richard J. Hebda

2007 Paleoecological Analysis of Lake Sediments Reveal Prehistoric Human Impact on Forests at Anthony Island UNESCO World Heritage Site, Queen Charlotte Islands (Haida Gwaii), Canada. Quaternary Research 68:177-183.

Lepofsky, Dana and Brian Pegg

1996 Archaeological and Ethnographic Assessment. In The Kawesas Watershed Assessment. Ecotrust, Portland.

Lepofsky, Dana, Michael Blake, Douglas Brown, Sandra Morrison, Nicole Oakes and Natasha Lyons

2000 The Archaeology of the Scowlitz Site, Southwest British Columbia. Journal of Field Archaeology 27(4):391-416.

Lesher, Robin D., and Jan A. Henderson

2010 Ecology and Distribution of Western Redcedar and Alaskan Yellowcedar in Northwestern Washington. In A Tale of Two Cedars: International Symposium on Western Redcedar and Yellow-Cedar, edited by Constance A. Harrington, pp. 1318. General Technical Report PNW-GTR-828. U.S. Department of Agriculture, Forest Service, Pacific Northwest Research Station, Portland.

Lightfoot, Kent

2006 Missions, Furs, Gold and Manifest Destiny: Rethinking an Archaeology of Colonialism for Western North America. In Historical Archaeology, Blackwell Studies in Global Archaeology, edited by M. Hall and S. W. Silliman, pp. 272292. Blackwell Publishing, Oxford.

Loferski, Joseph R.

1999 Technologies for Wood Preservation in Historic Preservation. Archives and Museum Informatics 13:273-290.

Losey, Robert

2005 House Remains at the Netarts Sandspit Village, Oregon. Journal of Field Archaeology 30(4):401-417. 
Marshall, Yvonne

2000 Transformations of Nuu-chah-nulth Houses. In Beyond Kinship: Social and Material Reproduction in House Societies, edited by Rosemary A. Joyce and Susan D. Gillespie, pp. 73-102. University of Pennsylvania Press, Philadelphia.

Martindale, Andrew, Bryn Letham, Duncan McLaren, David Archer, Meghan Burchell and Bernd R. Schone

2009 Mapping of Subsurface Shell Midden Components through Percussion Coring: Examples from the Dundas Islands. Journal of Archaeological Science 36:15651575 .

Mathieu, James R. and Daniel A. Meyer

1997 Comparing Axe Heads of Stone, Bronze and Steel: Studies in Experimental Archaeology. Journal of Field Archaeology 24:333-350.

Matson, R.G.

2003 The Coast Salish House: Lessons from Shingle Point, Valdes Island, British Columbia. In Emerging from the Mist: Studies in Northwest Coast Culture History, edited by R.G. Matson, Gary Coupland and Quentin Mackie, pp. 76-104. University of British Columbia Press, Vancouver.

Mauger, Jeffrey E.

1978 Shed Roof Houses at the Ozette Archaeological Site: A Protohistoric Architectural System. PhD dissertation, Department of Anthropology, Washington State University, Pullman.

Mauze, Marie

1998 Northwest Coast Trees: From Metaphors in Culture to Symbols for Culture. In The Social Life of Trees: Anthropological Perspectives on Tree Symbolism, edited by Laura M. Rival, pp. 233-251. Berg Press, Oxford.

McGuire, Randall H. and Michael B. Schiffer

1983 A Theory of Architectural Design. Journal of Anthropological Archaeology 2:277-303.

McGuire, Randall

1992 A Marxist Archaeologist. Academic Press, San Diego, California.

Moulton, Gary

1990 The Journals of the Lewis and Clark Expedition. University of Nebraska Press, Lincoln, Nebraska.

Nash, Donna 
2009 Household Archaeology in the Andes. Journal of Archaeological Research 17:205261.

Netting, Robert

1982 Some Truths on Household Size and Wealth. American Behavioral Scientist 25(6):641-662.

Niblack, Albert P.

1970 The Coast Indians of Southern Alaska and Northern British Columbia. Johnson Reprint Corp., New York.

Nielsen, Axel E.

1995 Architectural Performance and the Reproduction of Social Power. In Expanding Archaeology, edited by James M. Skibo, William H. Walker and Axel E. Nielson, pp. 47-66. University of Utah Press, Salt Lake City.

Oliver, Jeff

2007 Beyond the Water's Edge: Towards a Social Archaeology of Landscape on the Northwest Coast. Canadian Journal of Archaeology 31:1-27.

Oregon Historical Society

2003 Engraving of a Chinook Lodge in 1841. Electronic document, accessed May 7, 2012.

Park, Sharon C.

1989 The Repair and Replacement of Historic Wooden Shingle Roofs. Historic Preservation Brief Number 19. U.S.D.I., National Park Service.

Pauketat. Timothy and Susan M. Alt

2005 Agency in a Postmold? Physicality and the Archaeology of Culture-Making. Journal of Archaeological Method and Theory 12(3):213-237.

Pettigrew, Richard M.

1981 Prehistoric Culture Sequences in the Portland Basin of the Lower Columbia River Valley. Anthropological Papers Number 22. University of Oregon, Eugene, Oregon.

Poage, Nathan and J.C. Tappeiner

2005 Tree Species and Size Structure of Old-Growth Douglas Fir Forests in Central Western Oregon, USA. Forest Ecology and Management 204(2-3):329-343.

Pojar, James

2004 Plants of the Pacific Northwest Coast. Lone Pine Publishing, Edmonton, Alberta 
Rapoport, Amos

1969 House Form and Culture. Prentice-Hall, Englewood Cliffs, New Jersey.

Rathje, William and Randall McGuire

1982 Rich Men... Poor Men. In Archaeology of the Household: Building a Prehistory of Domestic Life. American Behavioral Scientist 25(6):705-716.

Reynolds, Peter

1995 The Life and Death of a Post-Hole. In Proceedings of the Fifth Interpreting Stratigraphy Conference, edited by E. Shepherd, pp. 21-25. Norwich, England.

Richardson, Allan

1982 The Control of Productive Resources on the Northwest Coast of North America. In Resources Managers: North American and Australian Hunter-Gatherers, edited by Nancy M. Williams and Eugene S. Hunn, pp. 93-112. American Association for the Advancement of Science Selected Symposium 67. Westview Press, Boulder, Colorado.

Robotham, Don

2012 Political Economy. In A Handbook of Economic Anthropology, edited by James G. Carrier, pp. 41-57. Edward Elgar Publishing, Cheltenham, United Kingdom.

Russell, John H. and Bob Daniels

2010 Variation in Western Redcedar Heartwood Extractives. In A Tale of Two Cedars: International Symposium on Western Redcedar and Yellow-Cedar, edited by Constance A. Harrington, pp. 83-86. General Technical Report PNW-GTR-828. U.S. Department of Agriculture, Forest Service, Pacific Northwest Research Station, Portland.

Saitta, Dean

1997 Power, Labor and the Dynamics of Change in Chacoan Political Economy. American Antiquity 62(1):7-26.

2012 Research Orientation. Electronic document, portfolio.du.edu/dsaitta, accessed January 27, 2013.

Schiffer, Michael B.

1972 Archaeological Context and Systemic Context. American Antiquity 37:156-165.

Shennan, Stephen

1997 Quantifying Archaeology. Edinburgh University Press, Edinburgh.

Skolmen, Roger G.

1968 Natural Durability of Some Woods Used in Hawaii. Bulletin PSW-167, Pacific Southwest Forest and Range Experiment Station, U.S. Department of Agriculture. 
Smith, Cameron M.

2004 The Social Organization of Production in Three Protohistoric Lower-Columbia River Plankhouses. PhD dissertation, Department of Anthropology, Simon Fraser University, Burnaby, British Columbia.

2006 Formation Processes of a Lower Columbia River Plankhouse Site. In Household Archaeology on the Northwest Coast, edited by Elizabeth A. Sobel, D. Ann Trieu Gahr, and Kenneth M. Ames, pp. 233-269. International Monographs in Prehistory, Ann Arbor.

Smith, Dan J., Alexander P. Mackie and Ian D. Sumpter

2005 Building Quaksweaqwul: Dendroarchaeological Investigations at Kiix?in National Historic Site, Vancouver Island, Canada. Dendrochronologia 22:195201.

Sobel, Elizabeth A.

2004 Social Complexity and Corporate Households on the Southern Northwest Coast of North America, A.D. 1450-1855. PhD dissertation, Department of Anthropology, University of Michigan, Ann Arbor.

Sollins, P., S.P. Cline, T. Verhoeven, D. Sachs and G. Spycher

1987 Patterns of Log Decay in Old-Growth Douglas Fir Forests. Canadian Journal of Forest Research 17:1585-1595.

Stanish, Charles

1989 Household Archaeology: Testing Models of Zonal Complementarity in the South Central Andes. American Anthropologist 91(1):7-24.

Steadman, Sharon

1996 Recent Research in the Archaeology of Architecture: Beyond the Foundations. Journal of Archaeological Research 4(1):51-93.

Stewart, Hilary

1984 Cedar: Tree of Life to the Northwest Coast Indians. University of Washington Press, Seattle.

Stryd, Arnoud H.

2001 Culturally Modified Trees of British Columbia: A Handbook for the Identification and Recording of Culturally Modified Trees. Archaeology Branch, British Columbia Ministry of Small Business, Tourism and Culture, prepared for the Resources Inventory Committee.

Suttles, Wayne 
1992 Handbook of North American Indians, vol. 7. Smithsonian Institution, Washington D.C.

Thoms, Alston V.

1998 Earth Ovens. In An Archaeology of Prehistoric North America, edited by Guy Gibbon, pp. 232. Garland Publishing, New York.

Tobalske, C.

2002 Historic Vegetation. Source: Oregon Natural Heritage Program, 1:100,000.

Trigger, Bruce

1993 Marxism and Contemporary Western Archaeology. Archaeological Method and Theory, edited by Michael Schiffer, pp. 159-200. Springer, New York.

Tringham, Ruth

2000 The Continuous House: A View from the Deep Past. In Beyond Kinship: Social and Material Reproduction in House Societies, pp. 115-134. The University of Pennsylvania Press, Philadelphia.

Turner, Nancy J. and James T. Jones

2000 Occupying the Land: Traditional Patterns of Land and Resource Ownership among First People of British Columbia. Paper presented at the Eighth Biennial Conference of the International Association for the Study of Common Property, Bloomington, Indiana.

Turner, Nancy J.

2004 Plants of Haida Gwaii. Sono Nis Press, Winlaw, British Columbia.

Van Gijseghem, Hendrik

2001 Household and Family at Moche, Peru: An Analysis of Building and Residence Patterns in a Prehispanic Urban Center. Latin American Antiquity 12(3):257-273.

Vastokas Joan M.

1966 Architecture of the Northwest Coast Indians of America. PhD dissertation, Department of Art, Columbia University, New York.

Verhoeven, Arno

2010 Posthole Archaeology. Medieval and Modern Matters 1:269-276.

Wainman, N., and R.W. Mathewes

1987 Forest History of the Last 12,000 Years based on Plant Macrofossil Analysis of Sediment from Marion Lake, Southwestern British Columbia. Canadian Journal of Botany 65(11): 2179-2187. 
Waring, R.H. and J.F. Franklin

1979 Evergreen Coniferous Forests of the Pacific Northwest. Science 204:1380-1386.

Wendt, Carl J.

2005 Excavations at El Remolino: Household Archaeology in the San Lorenzo Olmec Region. Journal of Field Archaeology 30(2): 163-180.

Whitlock, Cathy

1992 Vegetational and Climatic History of the Pacific Northwest during the Last 20,000 Years: Implications for Understanding Present-day Biodiversity.

The Northwest Environmental Journal, 8(5):5-28.

Wilk, Richard R., and William L. Rathje

1982 Household Archaeology. American Behavioral Scientist 25(6):617-639.

Williams, Raymond

1977 Marxism and Literature. Oxford University Press, Oxford.

Wilson, Charles W.

1866 Report on the Indian Tribes Inhabiting the Country in the Vicinity of the $49^{\text {th }}$ Parallel of North Latitude. Transactions of the Ethnological Society of London 4:275-332.

Wilson, Douglas C.

2009 Historical Archaeology at the Middle Village: Station Camp/McGowan Site (45PC106), Station Camp Unit, Lewis and Clark National Historic Park, Pacific County, Washington. Northwest Cultural Resources Institute Report Number 1. Vancouver, Washington.

Wolf, Eric

1999 Envisioning Power: Ideologies of Dominance and Crisis. University of California Press, Berkeley, California.

Worona, Marc A., and Cathy Whitlock

1995 Late Quaternary Vegetation and Climate History Near Little Lake, Central Coast Range, Oregon. Geologic Society of America Bulletin 107(7):867-869. 


\section{Appendix A: Architectural Features}

\section{Descriptive Statistics}

A total of 387 features related to house architecture were included in the Meier GIS database. In the field feature catalog, 199 architectural features were noted. In 2000, 104 features were added. Of these 303 total features, two were not included in analysis and were instead added to the Meier possible feature GIS database. Additionally, eight of these features were combined into four features, as they overlapped both horizontally and vertically. I added 90 features to the GIS database that were not listed in the catalog. These consist of 44 features that were documented in the excavation but were not recorded in the original feature catalog, including one step feature, four rocks associated with architectural features, and seven wall trench features. I reclassified 10 features that were originally classified as pits as postholes (Kenneth Ames, personal communication). I also added 36 new architectural features noted during reexamination of feature forms, level maps, wall profiles, unit ending maps and field notes.

Feature measurements at Meier did not conform to normal distributions when the Shapiro-Wilk test was performed (Table A-1). Table A-2 presents descriptive statistics of features at Meier with complete depth measurements (both upper and lower elevation measurements). It is important to note that these numbers do not necessarily represent the actual depth to which the structural element was buried in the ground, as parts of the original hole could have been cut off by subsequent building events.

Table A-1. Normal Distribution of Architectural Features at Meier (Shapiro-Wilk test).

\begin{tabular}{lccc}
\hline Feature Class & Length $^{1}$ & $\mathrm{Width}^{1}$ & Depth $^{2}$ \\
\hline Plankmolds & No $(\mathrm{W}=.743 \mathrm{df}=74 \mathrm{p}=.000)$ & No $(\mathrm{W}=.719, \mathrm{df}=74$, & No $(\mathrm{W}=.906, \mathrm{df}=65$, \\
& No $(\mathrm{W}=.522, \mathrm{df}=189$, & No $(\mathrm{W}=.524, \mathrm{df}=189$, & No $(\mathrm{W}=.619, \mathrm{df}=161$, \\
Postholes & $\mathrm{p}=.000)$ & $\mathrm{p}=.000)$ & $\mathrm{p}=.000)$ \\
& No $(\mathrm{W}=.795, \mathrm{df}=19$, & No $(\mathrm{W}=.721, \mathrm{df}=19$, & No $(\mathrm{W}=.890, \mathrm{df}=19$, \\
Postmolds & $\mathrm{p}<.005)$ & $\mathrm{p}=.000)$ & $\mathrm{p}<.05)$ \\
Combined & No $(\mathrm{W}=.660, \mathrm{df}=86$, & No $(\mathrm{W}=.692, \mathrm{df}=86$, & No $(\mathrm{W}=.611, \mathrm{df}=94$, \\
posts & $\mathrm{p}=.000)$ & $\mathrm{p}=.000)$ & $\mathrm{p}=.000)$
\end{tabular}

${ }^{\mathrm{I}}$ Complete horizontal measurements. ${ }^{2}$ Complete vertical measurements.

Table A-2. Architectural Features at Meier with both Upper and Lower Depth Measurement

\begin{tabular}{lccccc}
\hline \multicolumn{1}{c}{ Feature Class } & Count & $\begin{array}{c}\text { Minimum } \\
\text { Depth }(\mathrm{cm})\end{array}$ & $\begin{array}{c}\text { Maximum } \\
\text { Depth }(\mathrm{cm})\end{array}$ & $\begin{array}{c}\text { Mean Depth } \\
(\mathrm{cm})\end{array}$ & $\begin{array}{c}\text { Std. Deviation } \\
(\mathrm{cm})\end{array}$ \\
\hline Plankmold & 65 & 1.0 & 51.5 & 14.1 & 10.5 \\
Posthole & 161 & 1.0 & 142.0 & 16.4 & 19.5 \\
Postmold & 19 & 2.0 & 24.0 & 9.2 & 6.7 \\
Wall trench & 4 & 18.0 & 77.0 & 43.5 & 2.8 \\
\hline
\end{tabular}

Includes features with incomplete horizontal measurements. 
A total of 152 possible features were entered in a separate GIS database. Attributes described in this database were identical to architectural features database, although attribute fields for possible features were often incomplete or missing. Possible features comprised 16 plankmolds, 134 postholes, one step, and one wall trench. Many possible features represent small $(<7 \mathrm{~cm})$ postholes.

The Cathlapotle GIS database consists of 757 architectural features. Of these features, 743 were included in the original Cathlapotle feature catalog. I added 14 features based on reexamination of CAD drawings, photos, feature forms, level maps, wall profiles and unit ending maps. Feature measurements at Cathlapotle did not conform to normal distributions when the Shapiro-Wilk test was performed (Table A-3). Table A4 presents descriptive statistics of features with complete depth measurements. At Cathlapotle, an additional 247 possible features were included in the possible features database. These possible features consisted of 60 plankmolds, 97 postmolds, 72 postholes, 13 pegholes, two wall trenches, and three miscellaneous structural features.

Table A-3. Normal Distribution of Architectural Features at Cathlapotle.

\begin{tabular}{|c|c|c|c|}
\hline Feature Class & Length & Width & Depth \\
\hline Plankmolds & $\begin{array}{c}\text { No }(W=.932 \mathrm{df}=64 \\
p<.005)\end{array}$ & No $(\mathrm{W}=.613, \mathrm{df}=64, \mathrm{p}=.000)$ & $\begin{array}{c}\text { No }(\mathrm{W}=.804, \mathrm{df}=188, \\
\mathrm{p}=.000)\end{array}$ \\
\hline Postholes & $\begin{array}{c}\text { No }(\mathrm{W}=.750, \mathrm{df}=71, \\
\mathrm{p}=.000)\end{array}$ & No $(\mathrm{W}=.785 \mathrm{df}=71, \mathrm{p}=.000)$ & $\begin{array}{c}\text { No }(\mathrm{W}=.810, \mathrm{df}=82 \\
\mathrm{p}=.000)\end{array}$ \\
\hline Postmolds & $\begin{array}{c}\text { No }(\mathrm{W}=.742 \mathrm{df}=206, \\
\mathrm{p}=.000)\end{array}$ & No $(\mathrm{W}=.56, \mathrm{df}=206, \mathrm{p}=.000)$ & $\begin{array}{c}\text { No }(\mathrm{W}=.753, \mathrm{df}=268 \\
\mathrm{p}=.000)\end{array}$ \\
\hline Wall trenches & Not tested & Not tested & No $(\mathrm{W}=.874, \mathrm{df}=26, \mathrm{p}<.005)$ \\
\hline
\end{tabular}

${ }^{1}$ Complete horizontal measurements. ${ }^{2}$ Complete vertical measurements.

Table A-4. Cathlapotle Features with Both Upper and Lower Depth Measurements

\begin{tabular}{lccccc}
\hline & Count & $\begin{array}{c}\text { Minimum } \\
\text { Depth }(\mathrm{cm})\end{array}$ & $\begin{array}{c}\text { Maximum } \\
\text { Depth }(\mathrm{cm})\end{array}$ & $\begin{array}{c}\text { Mean Depth } \\
(\mathrm{cm})\end{array}$ & $\begin{array}{c}\text { Std. Deviation } \\
(\mathrm{cm})\end{array}$ \\
\hline Wall trench & 26 & 4.0 & 56.0 & 23.0 & 15.7 \\
Plankmold & 188 & 2.0 & 59.0 & 14.8 & 11.8 \\
Posthole & 82 & 2.0 & 60.0 & 12.0 & 8.6 \\
Postmold & 268 & 1.0 & 77.0 & 14.0 & 12.3 \\
\hline
\end{tabular}

Includes features with incomplete horizontal measurements.

\section{Spatial Distribution}

I created GIS maps that display feature size distribution using five size classes (Class 1: $7 \mathrm{~cm}$ or smaller, Class 2: 7.1-20 cm, Class 3: $20.1-40 \mathrm{~cm}$, Class 4: $40.1-70 \mathrm{~cm}$, Class 5:70.1 cm or larger). At Meier, there are several patterns in feature size class distribution (Figure A-1). Class 1 posts were distributed through the house interior, but were concentrated in hearth areas, supporting the supposition that these small posts represent pegs used in domestic or production activities. Class 2 and Class 3 posts were 
found in hearth and bench areas, strengthening the inference that they were used in small structures such as drying racks and sleeping platforms. Class 4 posts were found mostly along house walls, but also in interior areas. Class 4 posts found along walls likely served as eave beam support posts, while those in the interior would have been ridge beam support posts. Class 5 posts are predominantly found in house corners, and represent large corner support posts. One Class 5 post is located just inside the middle of the house structure. This post may represent a large central ridge beam support post. Overall at Meier, maps indicate that the largest features mostly occur in house walls and also in the center of the house, running parallel to long axis walls. These large posts and planks were likely used as eave and ridge beam supports. At Meier, it seems that large planks were used primarily for ridge beam supports, while large posts were used for corner posts.

Patterns in post feature size were also noted at Cathlapotle. Figure A-2 illustrates the dispersion of feature size classes through House 1. Small posts or pegs in Class 1 and 2 are most frequently located in hearth areas. Class 2 and Class 3 posts are often located in parallel rows in bench and interior central areas. Class 4 posts are found mostly in walls and also between compartments. Class 5 posts are located in the southern and eastern walls of Compartment D. Overall, large structural features in Cathlapotle House 1 are located in the house central interior and walls. Large planks are present in the central area, while larger posts were used primarily in walls or as part of compartments divisions.

Patterning of feature size class at Cathlapotle House 4 shows that Class 1 and 2 posts were found scattered in interior areas, presumably reflecting their use as pegs or for small structures (Figure A-3). As opposed to House 1, Class 3 posts were not well represented in interior areas, and were almost exclusively located close to house walls. Class 4 and Class 5 posts are less numerous than in House 1, and all but one of the posts from these classes are located in wall areas. Overall, almost all large structural features at House 4 are located in wall areas, although some Class 4 and Class 5 plankmolds are present in the central interior area of House 4. Overall, these maps suggest that smaller structural elements were used in the interior of House 4 compared to House 1, although this trend was not statistically significant (see Table 13).

\section{Descriptive Statistics of Subcategories}

Several subcategories of features were investigated to address specific research questions. Features from Cathlapotle were divided into groups based on location in House 1 or 4 (Table A-5). Plankmolds and postmolds from Cathlapotle House 1 were also divided in the subcategories based on compartment location (Table A-6). 


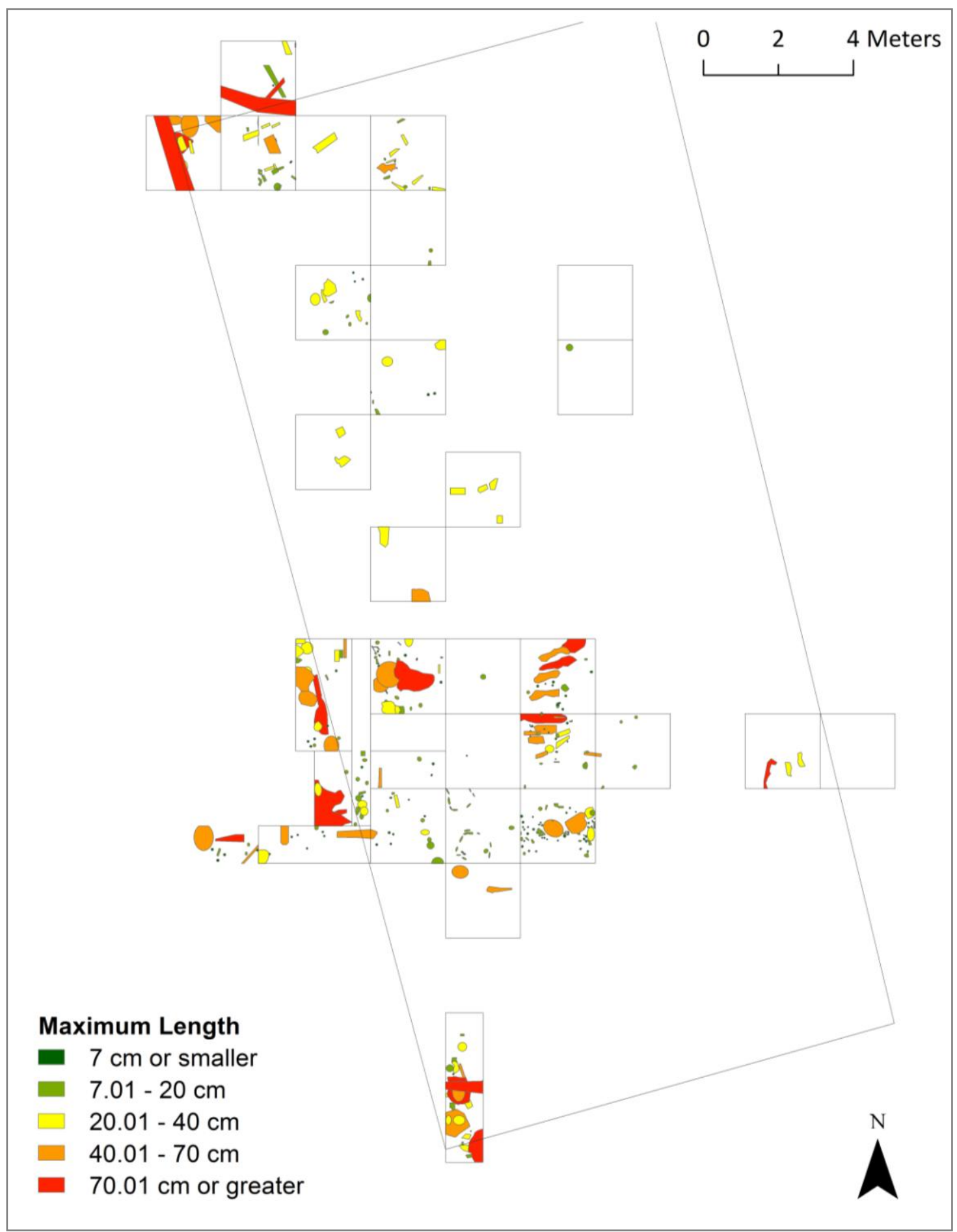

Figure A-1. Features by size, Meier. 


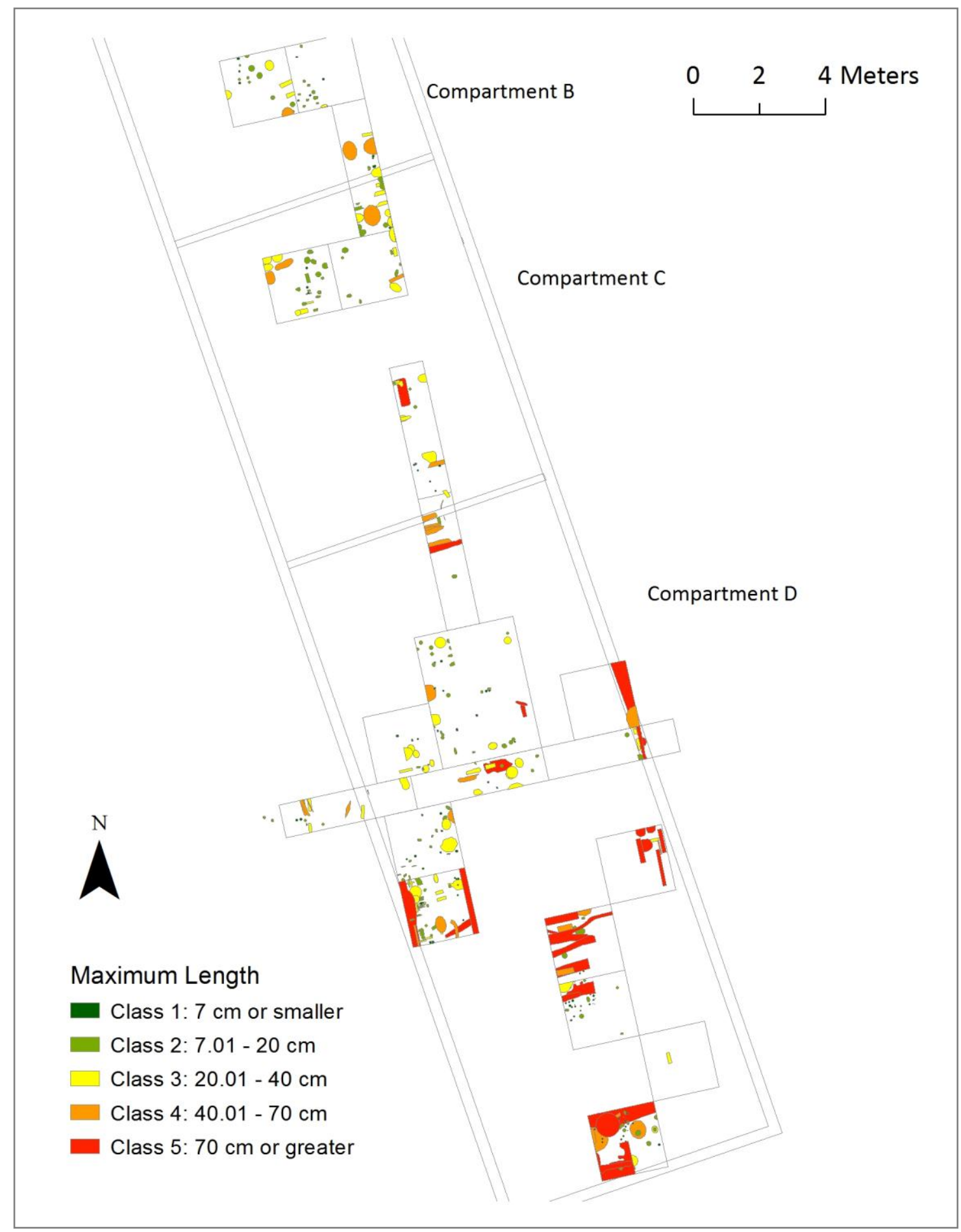

Figure A-2. Features by size, Cathlapotle House 1. 


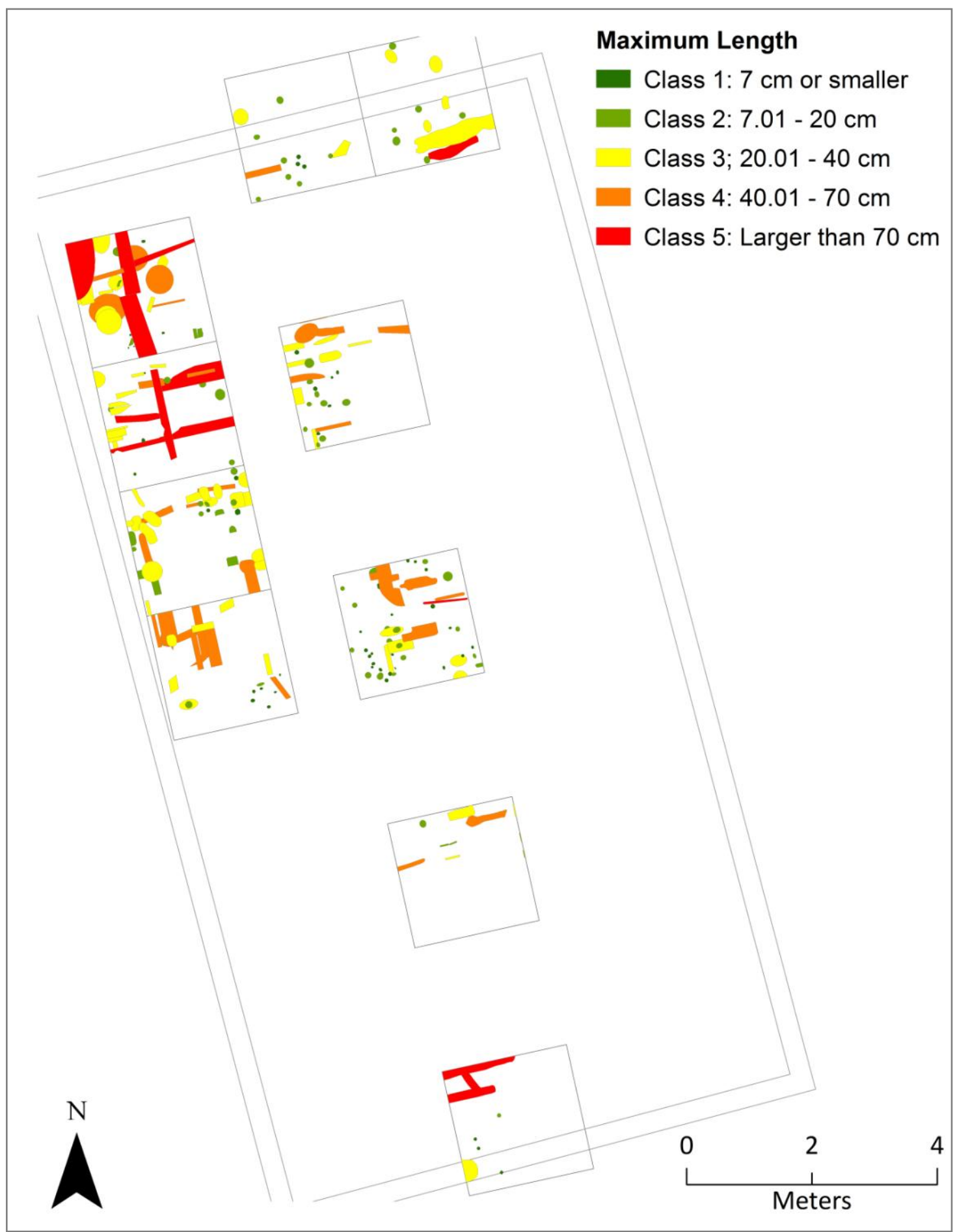

Figure A-3. Features by size, Cathlapotle House 4. 
Subcategories of features were created to compare features between facilities. Facilities employed for analysis at Meier consist of bench, cellar, hearth and wall, while those at Cathlapotle consist of hearth, bench and wall. Descriptive statistics for feature classes in each facility are presented in Tables A-7 and A-8.

Table A-5. Descriptive Statistics of Architectural Features with Complete Horizontal Measurements at Cathlapotle Houses 1 and 4.

\begin{tabular}{|c|c|c|c|c|c|c|c|c|c|}
\hline & & \multirow{2}{*}{\multicolumn{4}{|c|}{$\begin{array}{r}\text { House } 1 \\
\text { Std. }\end{array}$}} & \multicolumn{4}{|c|}{ House 4} \\
\hline & & & & & & & & Std. & \\
\hline & & Count & $\begin{array}{l}\text { Mean } \\
(\mathrm{cm})\end{array}$ & $\begin{array}{l}\text { Deviation } \\
(\mathrm{cm})\end{array}$ & $\begin{array}{l}\text { Median } \\
(\mathrm{cm})\end{array}$ & Count & $\begin{array}{c}\text { Mean } \\
(\mathrm{cm})\end{array}$ & $\begin{array}{l}\text { Deviation } \\
(\mathrm{cm})\end{array}$ & $\begin{array}{l}\text { Median } \\
\text { (cm) }\end{array}$ \\
\hline \multirow[t]{2}{*}{ Plankmold } & Length & 32 & 26.5 & 19.2 & 21 & 24 & 40.7 & 15.9 & 38.5 \\
\hline & Width & 32 & 9.9 & 12.7 & 6 & 24 & 9.3 & 4.9 & 7 \\
\hline \multirow[t]{2}{*}{ Posthole } & Length & 40 & 9.8 & 7.7 & 8 & 23 & 10.9 & 8.2 & 9 \\
\hline & Width & 40 & 8.8 & 7.4 & 7 & 23 & 9.4 & 5.3 & 8 \\
\hline \multirow[t]{2}{*}{ Postmold } & Length & 108 & 14.1 & 14.1 & 9 & 65 & 13.9 & 9.1 & 11 \\
\hline & Width & 108 & 11.8 & 11.8 & 8 & 65 & 12.8 & 15.4 & 10 \\
\hline \multirow[t]{2}{*}{ Total Posts } & Length & 148 & 12.9 & 11.8 & 9 & 88 & 13.2 & 8.9 & 10 \\
\hline & Width & 148 & 10.9 & 9.9 & 8 & 88 & 11.9 & 13.6 & 8.8 \\
\hline
\end{tabular}

Table A-6. Dimensions of Plankmolds and Postmolds found in Compartments of Cathlapotle House 1.

\begin{tabular}{|c|c|c|c|c|c|c|}
\hline & & & Count & $\operatorname{Mean}(\mathrm{cm})$ & Std. Deviation $(\mathrm{cm})$ & Median $(\mathrm{cm})$ \\
\hline \multirow[t]{4}{*}{ Plankmold } & \multirow[t]{2}{*}{ Compartment $\mathrm{C}$} & Length & 6 & 24.8 & 14.9 & 21 \\
\hline & & Width & 6 & 10.2 & 7.4 & 7.5 \\
\hline & \multirow[t]{2}{*}{ Compartment D } & Length & 26 & 26.9 & 20.3 & 21 \\
\hline & & Width & 26 & 9.9 & 13.7 & 6 \\
\hline \multirow[t]{6}{*}{ Postmold } & \multirow[t]{2}{*}{ Compartment B } & Length & 14 & 13.3 & 14.2 & 8 \\
\hline & & Width & 14 & 11.5 & 9.9 & 8 \\
\hline & \multirow[t]{2}{*}{ Compartment $\mathrm{C}$} & Length & 25 & 12.7 & 11.4 & 9 \\
\hline & & Width & 25 & 10.5 & 9.2 & 8 \\
\hline & \multirow[t]{2}{*}{ Compartment D } & Length & 69 & 14.8 & 13.2 & 10 \\
\hline & & Width & 69 & 12.2 & 11.3 & 8 \\
\hline
\end{tabular}

Compartment A was unexcavated. Compartment B contained no complete plankmolds.

Features were also categorized by structural class. Four structural elements types were used for this classification: corner posts, eave supports, ridge beam supports and wall planks. As discussed in Chapter 4, structural classes were assigned to features (when possible) based on house placement and morphology. Table A-9 presents feature metrics for structural element footprints at Meier and Cathlapotle.

Descriptive statistics of wall trenches were also calculated (Table A-10). Features from both sites were combined to increase sample size. It is important to note that depth may have been greater than recorded if intrusive features or soil mixing destroyed upper feature elevations. Additionally, the width of trenches may have grown with successive 
wall plank replacement episodes. Hence, these calculations are estimates and should not be taken precisely.

Table A-7. Architectural Metrics by Facility, Meier.

\begin{tabular}{lllcccc}
\hline & & Count & Mean $(\mathrm{cm})$ & Std. Deviation $(\mathrm{cm})$ & Median $(\mathrm{cm})$ \\
\hline Plankmold & Bench & Length & 21 & 17.14 & 11.03 & 14 \\
& & Width & 21 & 6.19 & 5.2 & 5 \\
& \multirow{2}{*}{ Cellar } & Length & 23 & 14.96 & 10.37 & 13 \\
& & Width & 23 & 4.61 & 3.12 & 4 \\
& \multirow{2}{*}{ Hearth } & Length & 21 & 25.86 & 16.42 & 18 \\
& & Width & 21 & 9.00 & 6.19 & 7 \\
& \multirow{2}{*}{ Wall } & Length & 6 & 42.67 & 41.83 & 25.5 \\
& & Width & 6 & 16.17 & 12.62 & 11.5 \\
\hline Total Posts & Bench & Length & 29 & 14.76 & 11.22 & 12 \\
(Posthole & & Width & 29 & 12.41 & 11.49 & 14 \\
and & Cellar & Length & 15 & 18.27 & 11.36 & 10 \\
Postmold) & & Width & 15 & 14.13 & 8.46 & 10 \\
& \multirow{2}{*}{ Hearth } & Length & 27 & 15.52 & 14.27 & 8 \\
& & Width & 27 & 11.63 & 12.31 & 23.5 \\
& \multirow{2}{*}{ Wall } & Length & 12 & 28.83 & 28.00 & 20.5 \\
\hline
\end{tabular}

Table A-8. Architectural Metrics by Facility, Cathlapotle.

\begin{tabular}{|c|c|c|c|c|c|c|}
\hline & & & Count & Mean $(\mathrm{cm})$ & Std. Deviation $(\mathrm{cm})$ & Median $(\mathrm{cm})$ \\
\hline \multirow[t]{6}{*}{ Plankmold } & \multirow[t]{2}{*}{ Hearth } & Length & 21 & 43.76 & 19.79 & 40 \\
\hline & & Width & 21 & 14.86 & 14.41 & 12 \\
\hline & \multirow[t]{2}{*}{ Bench } & Length & 3 & 21.00 & 14.73 & 13 \\
\hline & & Width & 3 & 3.67 & 2.89 & 2 \\
\hline & \multirow[t]{2}{*}{ Wall } & Length & 36 & 27.08 & 15.21 & 24 \\
\hline & & Width & 36 & 6.94 & 3.66 & 6 \\
\hline \multirow[t]{6}{*}{ Posthole } & \multirow[t]{2}{*}{ Hearth } & Length & 38 & 8.97 & 7.94 & 8 \\
\hline & & Width & 38 & 7.72 & 6.63 & 6 \\
\hline & \multirow[t]{2}{*}{ Bench } & Length & 3 & 11.67 & 11.55 & 5 \\
\hline & & Width & 3 & 10.00 & 8.66 & 5 \\
\hline & \multirow[t]{2}{*}{ Wall } & Length & 22 & 11.96 & 7.05 & 9.5 \\
\hline & & Width & 22 & 11.09 & 6.24 & 8.75 \\
\hline \multirow[t]{6}{*}{ Postmold } & \multirow[t]{2}{*}{ Hearth } & Length & 86 & 11.80 & 7.67 & 8.75 \\
\hline & & Width & 86 & 9.88 & 5.84 & 8 \\
\hline & \multirow[t]{2}{*}{ Bench } & Length & 22 & 14.36 & 10.70 & 9.5 \\
\hline & & Width & 22 & 11.23 & 9.49 & 7 \\
\hline & \multirow[t]{2}{*}{ Wall } & Length & 76 & 15.74 & 14.26 & 10 \\
\hline & & Width & 76 & 14.41 & 17.14 & 9 \\
\hline \multirow{6}{*}{$\begin{array}{l}\text { Post } \\
\text { (postmold } \\
\text { and } \\
\text { posthole) }\end{array}$} & \multirow[t]{2}{*}{ Hearth } & Length & 124 & 10.93 & 7.83 & 8 \\
\hline & & Width & 124 & 9.22 & 6.15 & 8 \\
\hline & \multirow[t]{2}{*}{ Bench } & Length & 25 & 14.04 & 10.59 & 9 \\
\hline & & Width & 25 & 11.08 & 9.23 & 7 \\
\hline & \multirow[t]{2}{*}{ Wall } & Length & 98 & 14.89 & 13.06 & 10 \\
\hline & & Width & 98 & 13.67 & 15.41 & 9 \\
\hline
\end{tabular}


Table A-9. Feature Metrics for each Structural Class.

\begin{tabular}{|c|c|c|c|c|c|c|c|c|c|}
\hline & \multicolumn{5}{|c|}{ Length (cm) } & \multicolumn{4}{|c|}{ Width $(\mathrm{cm})$} \\
\hline & $\begin{array}{l}\vec{\Xi} \\
\dot{0}\end{array}$ & 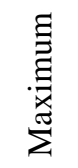 & 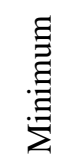 & $\sum^{\varpi}$ & 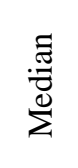 & 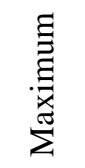 & $\begin{array}{l}\text { 声 } \\
\text { 禀 }\end{array}$ & $\underbrace{\varpi \pm}_{\Sigma}$ & 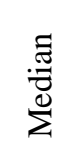 \\
\hline \multicolumn{10}{|l|}{$\underline{\text { Meier }}$} \\
\hline Corner Post & 8 & 110 & 38 & 71.8 & 73 & 78 & 25 & 51.9 & 52.5 \\
\hline Eave Support & 17 & 129 & 16 & 41.2 & 30 & 78 & 10 & 35.8 & 27.0 \\
\hline Ridge Beam Support & 15 & 103 & 24 & 54.2 & 48.8 & 62 & 8 & 25.3 & 24.0 \\
\hline Wall Plank & 13 & 38 & 21 & 38.0 & 36.0 & 21 & 5 & 11.7 & 10.0 \\
\hline \multicolumn{10}{|l|}{ Cathlapotle } \\
\hline$\overline{\text { Corner Post }}$ & 1 & 143 & 143 & 143 & - & 143 & 98 & 98 & 98 \\
\hline Eave Support & 42 & 89 & 16 & 35.7 & 16.5 & 31.5 & 65 & 12 & 28.9 \\
\hline Ridge Beam Support & 57 & 124 & 15 & 60.0 & 22.9 & 48.0 & 78 & 2 & 25.2 \\
\hline Wall Plank & 25 & 112 & 15 & 47.6 & 29.0 & 40.0 & 63 & 3 & 12.1 \\
\hline
\end{tabular}

Table A-10. Combined Wall Trench Measurements, Cathlapotle and Meier.

\begin{tabular}{ccccccc}
\hline & Count & Minimum $(\mathrm{cm})$ & Maximum $(\mathrm{cm})$ & Mean $(\mathrm{cm})$ & Std Deviation $(\mathrm{cm})$ & Median $(\mathrm{cm})$ \\
\hline Depth & 30 & 4.0 & 77.0 & 25.8 & 18.5 & 23.5 \\
Width & 31 & 4.0 & 120.0 & 38.0 & 31.8 & 29.0 \\
\hline
\end{tabular}




\section{Appendix B: Structural Element and Materials Calculations}

\section{Metrics of Structural Elements}

When possible, metrics of structural elements were based on feature size data from the Meier and Cathlapotle excavations. However, consultation of ethnographies, historical documents and other archaeological excavations was required to determine the metric attributes of some elements that left no archaeological correlates at Meier and Cathlapotle, such as element height and beam diameter. Wall plank, corner post and eave support height was based on ethnographic and historical sources cited by Hajda (1994) and Ames et al. (1992) and was estimated at 1.5-2.4 m. Ridge beam support height was based on these same sources and was estimated at 4-6.1 m. Beam diameter was estimated from Stewart (1984), who reported beams diameters of 0.6-1.2 m, and from Ozette data. Although Ozette plankhouses were not architecturally identical to those in the LCRR, they represent one of the only data sets for examining certain architectural elements. Beam dimensions were approximated using the dimensions of notches of support posts that held beams (Mauger 1978:99-104). At Ozette, notches ranged in width from .32-.51 $\mathrm{m}$. This number was used as an approximation of minimum beam diameter. Since Stewart included very large houses in her sample, and the Ozette houses were smaller than the Meier House and Cathlapotle House 1, an estimate of .3-1 m for beam diameter was employed.

\section{Quantity of Structural Elements}

Quantification of each type of structural element per house is possible with the aid of historical sources and archaeological data from Ozette. Table B-1 presents estimated number of structural elements in each house studied at Meier and Cathlapotle. Distance between structural elements and house measurements were used to extrapolate number of elements in each house. Distances were derived from historical accounts and sketches (Hadja 1994), and from Ozette data (Matson 2003; Mauger 1978). A caveat is that houses at Ozette were built in the shed roof style, and so had pairs of rafter support posts rather than ridge and eave beam support posts. Ozette House 1 had five pairs of rafter support posts, and distance between them ranged from 4-5.2 meters. Ozette House 2 had four pairs of rafter support posts, ranging from 4-6.4 m apart (Matson 2003:Figure 4.11). For this study, eave and ridge beam support posts were considered to be 4-6 $\mathrm{m}$ apart. Each house was assumed to have four corner posts, with four corner posts in each compartment of Cathlapotle House 1. 
Number of wall planks in each house was estimated by dividing the house length by the median plank length of $40 \mathrm{~cm}$, which was determined using Meier and Cathlapotle metrics and measurements cited in historical documents. Median plank length at the sites ranged from 14-30 cm. However, these numbers are smaller because of the inclusion of planks used in benches, as pit liners, and in other house structures. Features assigned to the wall plank class had median lengths of $38 \mathrm{~cm}$ at Meier and $48 \mathrm{~cm}$ at Cathlapotle. Therefore, using the means and medians from Meier and Cathlapotle structural features, it is reasonable to use $40 \mathrm{~cm}$ as a default plank length for wall planks.

Table B-1. Number of Structural Elements in each House, Meier and Cathlapotle.

\begin{tabular}{|c|c|c|c|c|c|c|}
\hline & \multirow[b]{2}{*}{ Meier } & \multirow[b]{2}{*}{$\begin{array}{c}\text { Cathlapotle } \\
\text { House 1B }\end{array}$} & \multirow[b]{2}{*}{$\begin{array}{c}\text { Cathlapotle } \\
\text { House 1C }\end{array}$} & \multicolumn{3}{|c|}{ Cathlapotle } \\
\hline & & & & $\begin{array}{c}\text { Cathlapotle } \\
\text { House 1D }\end{array}$ & $\begin{array}{c}\text { House } 1 \\
\text { Total }\end{array}$ & $\begin{array}{c}\text { Cathlapotle } \\
\text { House } 4\end{array}$ \\
\hline Corner Post & 4 & 4 & 4 & 4 & 16 & 4 \\
\hline Eave Beam Support* & $6-12$ & 0 & 2 & $2-6$ & $6-16$ & $0-2$ \\
\hline Ridge Beam & $10-16$ & $2-4$ & $4-6$ & $6-10$ & $22-32$ & $4-6$ \\
\hline Support* & & & & & & \\
\hline Wall Plank & 220 & 83 & 107 & 144 & 379 & 107 \\
\hline Ridge Beam & 1 & 1 & 1 & 1 & 1 & 1 \\
\hline Eave Beam & 2 & 2 & 2 & 2 & 2 & 2 \\
\hline
\end{tabular}

*Represent minimums and maximums based on different estimations of distance between elements.

\section{Surface Area Calculations}

In order to determine board feet of planking required for houses, I calculated the surface area that would need to be sheathed with planks for siding and roofing. Roof area was calculated using the Pythagorean Theorem (Figure B-1). Wall plank height, ridge beam support height, and structure width were used to complete this equation. Side A was determined

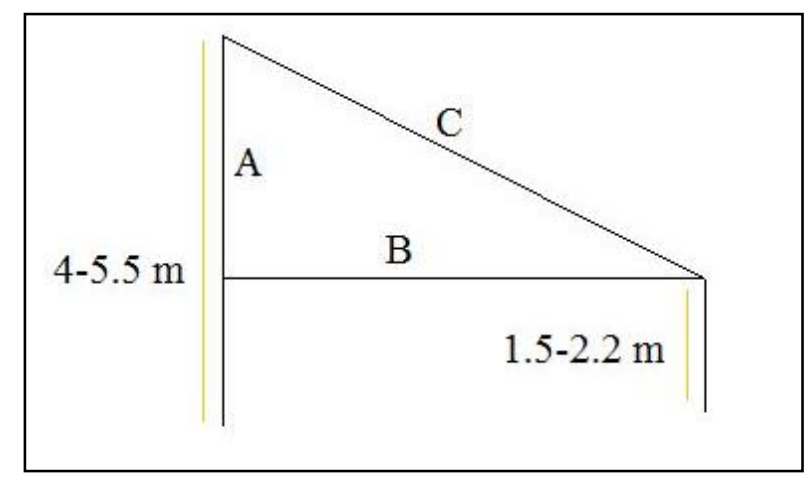

Figure B-1. Schematic of roof area calculations. by subtracting ridge beam support height from wall height. Side B was calculated by halving the width of the house. Side C was completed with the Pythagorean Theorem, and represents estimated roof width. Roof width was multiplied by the length of the house. This figure was multiplied by two (to account for both sides of the roof), which represents the total roof area in square meters. For each structure, four roof area calculations were obtained representing the different combinations of ridge beam and wall height (Table B-2). 
Table B-2. Roof Area Given Different House Measurements, Meier and Cathlapotle.

\begin{tabular}{lccccc}
\hline & $\begin{array}{c}\text { Wall } \\
\text { Height }(\mathrm{m})\end{array}$ & $\begin{array}{c}\text { Ridge Beam } \\
\text { Support Height }(\mathrm{m})\end{array}$ & $\begin{array}{c}\text { Roof } \\
\text { Width }(\mathrm{m})\end{array}$ & $\begin{array}{c}\text { Roof } \\
\text { Length }(\mathrm{m})\end{array}$ & $\begin{array}{c}\text { Total Roof } \\
\text { Area }\left(\mathrm{m}^{2}\right)\end{array}$ \\
\hline Meier & 1.5 & 4 & 7.43 & 30 & 445.8 \\
& & 6.1 & 8.38 & 30 & 502.8 \\
& 2.4 & 4 & 7.18 & 30 & 430.8 \\
& & 6.1 & 7.92 & 30 & 475.2 \\
\hline Cathlapotle House 4 & 1.5 & 4 & 4.76 & 13.2 & 125.7 \\
& & 6.1 & 5.69 & 13.2 & 161.8 \\
& 2.4 & 4 & 4.43 & 13.2 & 114.8 \\
& & 6.1 & 4.36 & 13.2 & 144.8 \\
\hline Cathlapotle House 1B & 1.5 & 4 & 5.59 & 6.6 & 73.8 \\
& & 6.1 & 6.4 & 6.6 & 89.7 \\
& 2.4 & 4 & 5.31 & 6.6 & 69.3 \\
& & 6.1 & 5.99 & 6.6 & 82.1 \\
\hline Cathlapotle House 1C & 1.5 & 4 & 5.59 & 11.3 & 126.3 \\
& & 6.1 & 6.4 & 11.3 & 153.5 \\
& 2.4 & 4 & 5.31 & 11.3 & 118.7 \\
& & 6.1 & 5.99 & 11.3 & 140.6 \\
\hline Cathlapotle House 1D & 1.5 & 4 & 5.59 & 18.7 & 209.1
\end{tabular}

Since roof area made up a significant portion of the raw material required for houses, I wanted ensure that my calculations were reasonable. To test roof area calculations, two angles of the roof pitch were calculated for each possible wall height and roof beam support combination that were used to estimate roof area. Angle A

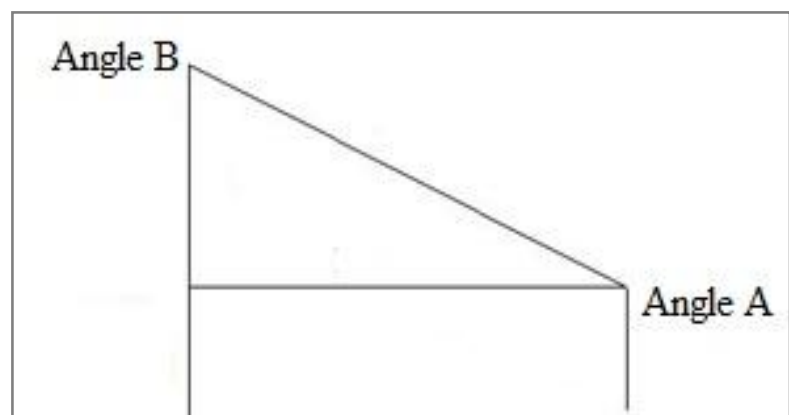

Figure B-2. Schematic of roof angle calculations. represents the intersection of the wall and the roof, and Angle B represents the pitch of the roof (Figure B-2). These angles were then compared to two historical depictions of LCRR plankhouses. In Paul Kane's painting (Interior of a Ceremonial Lodge), Angle A is 22 degrees and Angle B is 68 degrees (Eaton and Urbanek 1995). In the Richard Dodson's engraving (Chinook Lodge in 1841, based a sketch by Alfred Agate), Angle A is 37 degrees and Angle B is 51 degrees (Oregon Historical Society 2003). These numbers are within the ranges of angles that I calculated from feature height estimates (Table B-3). 
Table B-3. Angles of Roof Pitch Given Different House Measurements, Meier and Cathlapotle.

\begin{tabular}{lcccc}
\hline & Wall Height $(\mathrm{m})$ & Ridge Beam Support Height $(\mathrm{m})$ & Angle A & Angle B \\
\hline Meier & 1.5 & 4 & 19.7 & 70.3 \\
& & 6.1 & 32.2 & 57.8 \\
& 2.4 & 4 & 12.9 & 77.1 \\
& & 6.1 & 27.9 & 62.1 \\
\hline Cathlapotle House 4 & 1.5 & 4 & 31.7 & 58.3 \\
& \multirow{2}{*}{2.4} & 6.1 & 44.8 & 45.2 \\
& & 4 & 34.7 & 55.3 \\
& \multirow{2}{*}{1.5} & 6.1 & 42.4 & 47.6 \\
\hline Cathlapotle House 1 & \multirow{2}{*}{2.4} & 6.1 & 26.6 & 63.4 \\
& & 4 & 42.6 & 47.4 \\
& & 6.1 & 17.7 & 72.3 \\
& & & 36.5 & 53.5 \\
\hline
\end{tabular}

Wall area was also calculated for each possibility of wall height and ridge beam support height combination (Table B-4). Total wall area was calculated by multiplying the long axis wall area by two and the short axis wall area by two and adding these numbers. The short axis calculation took into account the triangular portion of the short axis wall. Again, four different numbers for each house were created using all possible combinations of wall height and ridge beam support post height.

Table B-4. Wall Surface Area Calculations Given Different House Measurements, Meier and Cathlapotle.

\begin{tabular}{lccccc}
\hline & $\begin{array}{c}\text { Long Axis Wall } \\
\text { Height }(\mathrm{m})\end{array}$ & $\begin{array}{c}\text { Ridge Beam } \\
\text { Height }(\mathrm{m})\end{array}$ & $\begin{array}{c}\text { Long Axis } \\
\text { Wall Area }\left(\mathrm{m}^{2}\right)\end{array}$ & $\begin{array}{c}\text { Short Axis } \\
\text { Area }\left(\mathrm{m}^{2}\right)\end{array}$ & $\begin{array}{c}\text { Total House } \\
\text { Siding Area }\left(\mathrm{m}^{2}\right)\end{array}$ \\
\hline Meier & 1.5 & 4 & 45 & 38.50 & 167.0 \\
& & 6.1 & & 53.2 & 196.4 \\
& 2.4 & 4 & 72 & 44.8 & 233.6 \\
\hline Cathlapotle & 1.5 & 4.1 & & 59.5 & 263.0 \\
House 4 & & 6.1 & 19.8 & 22.27 & 84.1 \\
& 2.4 & 4 & 31.68 & 30.78 & 101.2 \\
& & 6.1 & & 26.74 & 116.8 \\
\hline Cathlapotle & 1.5 & 4 & 9.9 & 27.5 & 132.2 \\
House 1B & & 6.1 & & 38 & 94.8 \\
& 2.4 & 4 & 15.84 & 32 & 95.8 \\
& & 6.1 & & 42.5 & 116.7 \\
\hline Cathlapotle & 1.5 & 4 & 16.95 & 27.5 & 88.9 \\
House 1C & & 6.1 & & 38 & 109.9 \\
& 2.4 & 4 & 27.12 & 32 & 118.2 \\
& & 6.1 & & 42.5 & 139.2 \\
\hline Cathlapotle & 1.5 & 4 & 28.05 & 27.5 & 111.1 \\
House 1D & & 6.1 & & 38 & 132.1 \\
& 2.4 & 4 & 44.88 & 32 & 153.8 \\
& & 6.1 & & 42.5 & 174.8 \\
\hline Cathlapotle & 1.5 & 4 & 98.7 & 27.5 & $362.4^{*}$ \\
Total House 1 & \multirow{2}{*}{2.2} & 6.1 & 157.92 & 38 & $425.4^{*}$ \\
& & 6.1 & & 42.5 & $507.8^{*}$ \\
& & & & & $570.8^{*}$ \\
\hline
\end{tabular}

* House 1 total uses five total short axis siding figures to account for the wood used in dividing the compartments. 


\section{Post and Beam Calculations}

Number of elements in each house was combined with element height to estimate meters of wood required for posts and beam elements (Table B-5). A useable tree height of 6.1 meters (20 feet) was employed to maintain consistency with methods for calculating board feet. This number was divided by meters of wood needed for each diameter size $(1 \mathrm{~m}, .5 \mathrm{~m}$ and $.3 \mathrm{~m})$ needed for different post and beam elements. Fractional numbers were rounded up in final calculations of number of trees required.

Table B-5. Trees Needed for Initial Construction, Meier and Cathlapotle.

\begin{tabular}{|c|c|c|c|c|c|c|}
\hline & Element & $\begin{array}{l}\text { Diameter } \\
(\mathrm{m})\end{array}$ & $\begin{array}{l}\text { Height } \\
\text { (m) }\end{array}$ & Count & $\begin{array}{c}\text { Wood } \\
\text { Required (m) }\end{array}$ & $\begin{array}{c}\text { Trees } \\
\text { Required }\end{array}$ \\
\hline \multirow[t]{4}{*}{ Meier } & Corner post & 1 & $1.5-2.4$ & 4 & $6-9.6$ & $1-2$ \\
\hline & $\begin{array}{l}\text { Ridge beam } \\
\text { support }\end{array}$ & .5 & $4-6.1$ & $5-8$ & $20-48.8$ & $4-8$ \\
\hline & Eave beam support & .3 & $1.5-2.4$ & $6-12$ & $9-28.8$ & $2-5$ \\
\hline & Beam & $.3-1$ & 30 & 3 & 90 & $\begin{array}{c}15 \\
22-30\end{array}$ \\
\hline \multirow[t]{4}{*}{ Cathlapotle House 4} & Corner post & 1 & $1.5-2.4$ & 4 & $6-9.6$ & $1-2$ \\
\hline & $\begin{array}{l}\text { Ridge beam } \\
\text { support }\end{array}$ & .5 & $4-6.1$ & $2-3$ & $8-18.3$ & $2-3$ \\
\hline & Eave beam support & .3 & $1.5-2.4$ & $0-2$ & $0-4.4$ & $0-1$ \\
\hline & Beam & $.3-1$ & 13.2 & 3 & 39.6 & $\begin{array}{c}7 \\
10-13\end{array}$ \\
\hline \multirow[t]{4}{*}{ Cathlapotle House 1} & Corner post & 1 & $1.5-2.4$ & 16 & 24-38.4 & $4-7$ \\
\hline & $\begin{array}{l}\text { Ridge beam } \\
\text { support }\end{array}$ & .5 & $4-6.1$ & $11-16$ & $44-97.6$ & $8-16$ \\
\hline & Eave beam support & .3 & $1.5-2.4$ & $6-16$ & $9-38.4$ & $2-7$ \\
\hline & Beam & $.3-1$ & 65.8 & 3 & 197.4 & $\begin{array}{c}33 \\
47-63\end{array}$ \\
\hline
\end{tabular}

